Portland State University

PDXScholar

Summer 8-2-2018

\title{
Rock Glaciers of the Contiguous United States: Spatial Distribution, Cryospheric Context, and Riparian Vegetation
}

Gunnar Forrest Johnson

Portland State University

Follow this and additional works at: https://pdxscholar.library.pdx.edu/open_access_etds

Part of the Environmental Sciences Commons, and the Glaciology Commons Let us know how access to this document benefits you.

Recommended Citation

Johnson, Gunnar Forrest, "Rock Glaciers of the Contiguous United States: Spatial Distribution, Cryospheric Context, and Riparian Vegetation" (2018). Dissertations and Theses. Paper 4507.

https://doi.org/10.15760/etd.6391

This Dissertation is brought to you for free and open access. It has been accepted for inclusion in Dissertations and Theses by an authorized administrator of PDXScholar. Please contact us if we can make this document more accessible: pdxscholar@pdx.edu. 
Rock Glaciers of the Contiguous United States: Spatial Distribution, Cryospheric Context, and Riparian Vegetation

\author{
by \\ Gunnar Forrest Johnson
}

A dissertation submitted in partial fulfillment of the requirements for the degree of

\author{
Doctor of Philosophy \\ in \\ Environmental Sciences and Resources
}

\author{
Dissertation Committee: \\ Heejun Chang, Chair \\ Sarah Eppley \\ William Fish \\ Martin Lafrenz \\ Yandong Pan
}

\author{
Portland State University \\ 2018
}


(C) 2018 Gunnar Forrest Johnson 


\section{Abstract}

Continental-scale inventories of glaciers are available, but no analogous rock glacier inventories exist. We present the Portland State University Rock Glacier Inventory $(n=10,343)$ for the contiguous United States, then compare it to an existing inventory of contiguous United States glaciers $(n=853)$, identifying geographic and climatic factors affecting the spatial distributions observed. At least one rock glacier is identified in each of the 11 westernmost states, but nearly $90 \%$ are found in just five; Colorado $(n=3889)$, Idaho $(n=1723)$, Montana $(n=1780)$, Utah $(n=834)$, and Wyoming $(n=849)$. Glaciers are concentrated in relatively humid mountain ranges, while rock glaciers are concentrated in relatively arid mountain ranges. Mean glacier area $(0.60 \pm 0.073$ $\left.\mathrm{km}^{2}\right)$ is significantly greater than mean rock glacier area $\left(0.10 \pm 0.002 \mathrm{~km}^{2}\right)$, though total glacier area $\left(507.70 \mathrm{~km}^{2}\right)$ is lower than total rock glacier area $\left(1008.91 \mathrm{~km}^{2}\right)$. Glacier and rock glacier areas, as a percent of small watersheds containing them, are modeled using geographically weighted regression. Glacier percent area $\left(R^{2}=0.55\right)$ is best explained by elevation range and mean fall snowfall, while rock glacier percent area $\left(R^{2}=0.42\right)$ is best explained by mean spring dewpoint temperature and slope standard deviation. Finally, we compare riparian vegetation along meltwater streams draining glaciers and rock glaciers. Initial $500 \mathrm{~m}$ long meltwater stream reaches emanating from a total of 35 pairs of collocated glaciers and rock glaciers were delineated, allowing estimation of 
riparian vegetation cover and density. Rock glacier meltwater stream riparian vegetation cover (mean cover $=86.2 \% \pm 9.3 \%)$ and density $($ mean NDVI $=0.30 \pm$ $0.02)$ are significantly greater $(p$-value $<0.05)$ than glacier meltwater stream riparian vegetation cover (mean cover $=64.5 \% \pm 10.9 \%$ ) and density (mean $N D V I=0.13 \pm 0.01)$. This study shows that while the spatial distributions of glaciers and rock glaciers are both generally influenced by a combination of geographic and climatic variables, the specific forcings and local magnitudes are distinct for each cryospheric feature type, and processes inherent to rock glacier cryospheric meltwater sourcing positively influence first-order meltwater stream vegetation patterns. 


\section{Dedication}

To my parents. 


\section{Acknowledgments}

Thanks and appreciation to all who helped me along this long and winding path. 


\section{Table of Contents}

Abstract.tion.

Chapter 3: Comparative Analysis of Contiguous United States Glacier and Rock

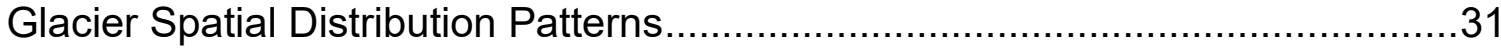

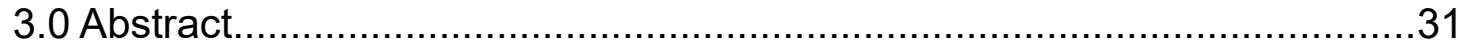

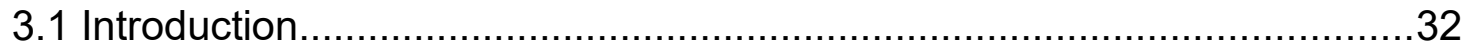

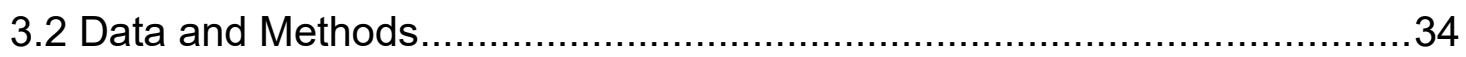

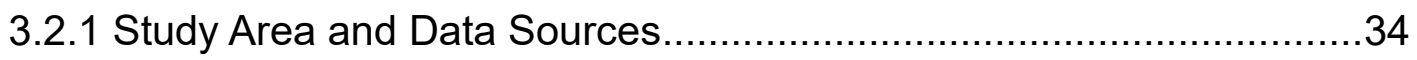

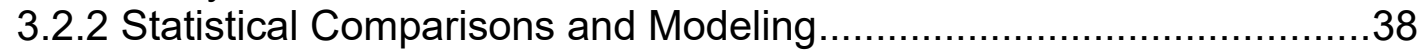

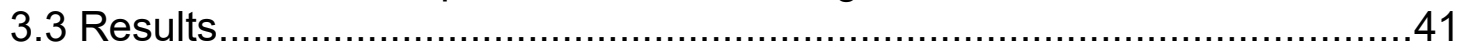

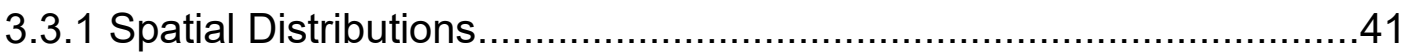

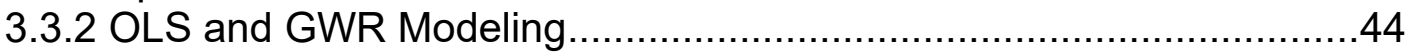

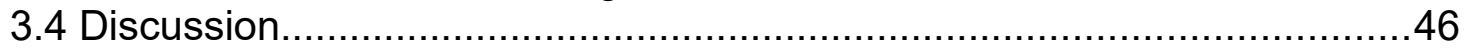

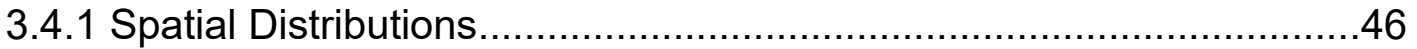

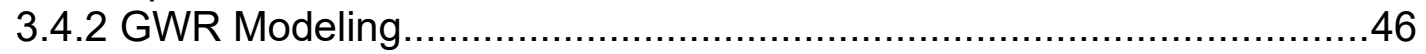

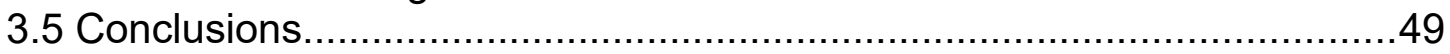

Chapter 4: Comparative Analysis of Contiguous United States Glacier and Rock

Glacier Meltwater Stream Riparian Vegetation...............................................52

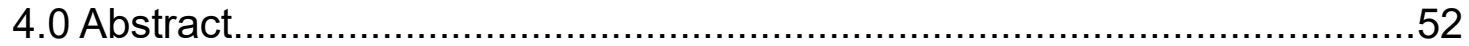

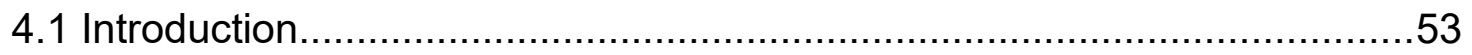

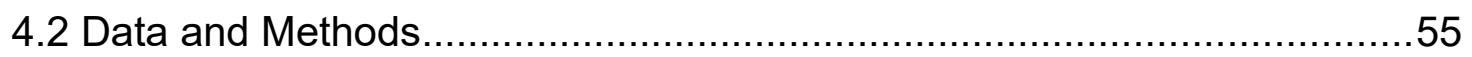

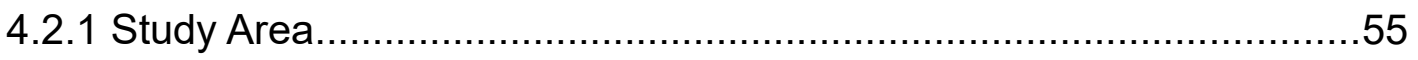




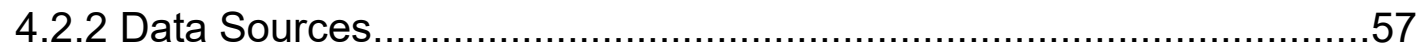

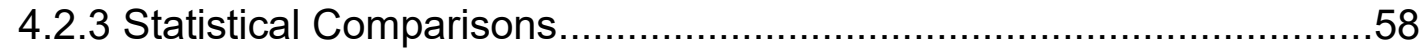

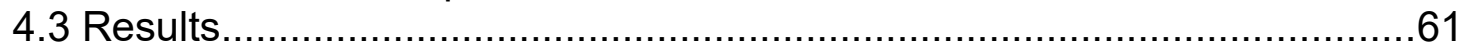

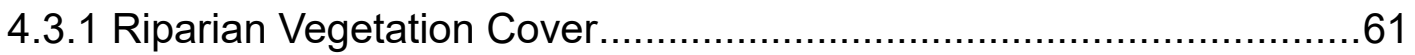

4.3.2 Riparian Vegetation Density.....................................................62

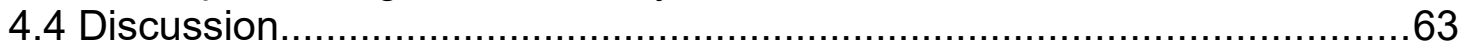

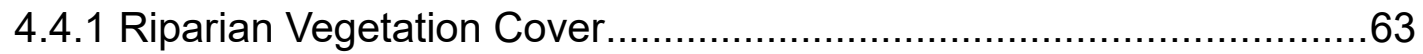

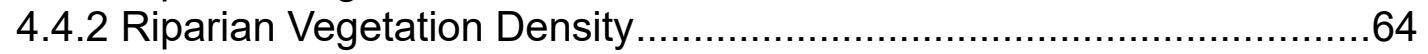

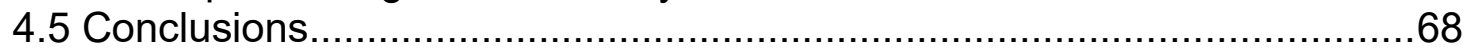

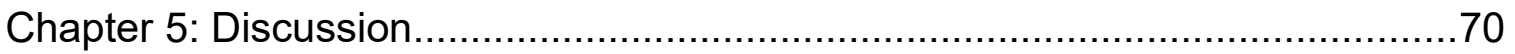

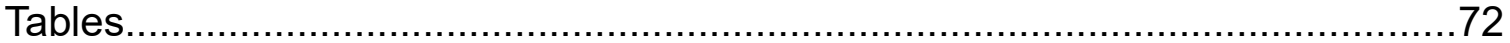

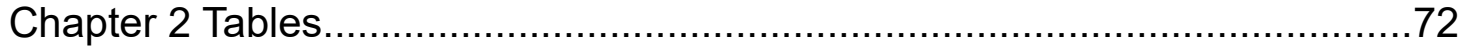

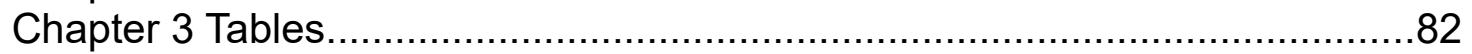

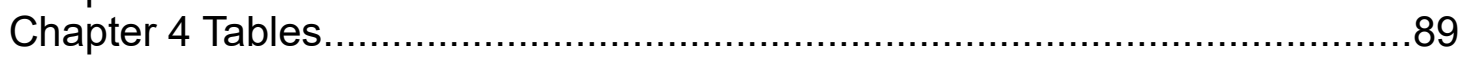

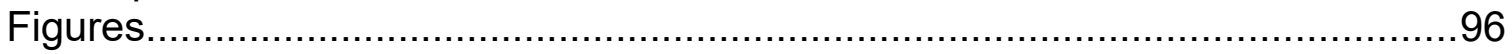

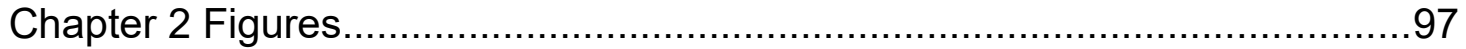

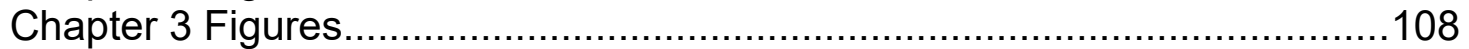

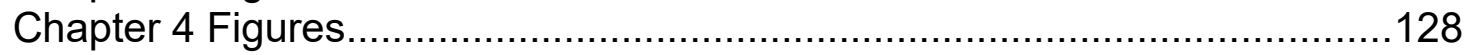

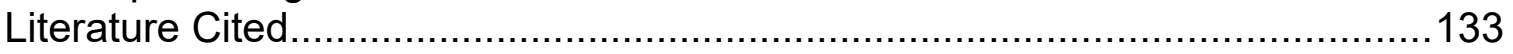




\section{List of Tables}

Table 1: Notable previous rock glacier inventories identified during comprehensive literature review.

Table 2: Ancillary GIS data used as explanatory variables in Chapter 2.

Table 3: Summary topographic and atmospheric statistics for Chapter 2 HUC12 rock glacier model calibration and validation domains.

Table 4: Summary 2011 NLCD land cover statistics for Chapter 2 HUC12 rock glacier model calibration and validation domains

Table 5: Rock glacier counts by class and NOAA region.

Table 6: Chapter 2 rock glacier OLS and GWR calibration model comparisons

overview.

Table 7: Chapter 2 rock glacier OLS and GWR validation model comparisons overview.

Table 8: Chapter 2 rock glacier OLS and GWR global model comparisons

overview.

Table 9: Global Moran's Index clustering statistics for Chapter 2 rock glacier OLS

and GWR models standardized residuals.

Table 10: Locally significant Chapter 2 rock glacier final GWR global model

variable sign change statistics.

Table 11: Ancillary GIS data used as explanatory variables in Chapter 3.

Table 12: Summary statistics for Chapter 3 HUC12 glacier model calibration and validation domains.

Table 13: Summary statistics for Chapter 3 HUC12 rock glacier model calibration and validation domains.

Table 14: Chapter 3 glacier OLS and GWR calibration, validation and global model comparisons overview.

Table 15: Global Moran's Index clustering statistics for Chapter 3 OLS and GWR

glacier models standardized residuals.

Table 16: Chapter 3 rock glacier OLS and GWR calibration, validation and global

model comparisons overview.

Table 17: Global Moran's Index clustering statistics for Chapter 3 OLS and GWR rock glacier models standardized residuals.

Table 18: Riparian zone topographic and climatic characteristics for 35 pairs of

$500 \mathrm{~m}$ long glacier and rock glacier first-order meltwater stream segments.

Table 19: Riparian zone percent cover characteristics for individual NLCD 2011 classes, as well as a single "combined vegetated" class, along 35 pairs of $500 \mathrm{~m}$ long glacier and rock glacier first-order meltwater stream segments.....

Table 20: Meltwater stream riparian vegetation cover OLS model summary.......91 Table 21: Glacier and rock glacier meltwater stream riparian vegetation density by growing season. 
Table 22: Glacier and rock glacier meltwater stream riparian vegetation density

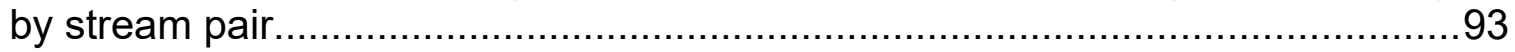

Table 23: Meltwater stream riparian vegetation density OLS model summary....95 


\section{List of Figures}

Figure 1: Examples of each of the three rock glacier classes shown in both plan view and oblique upslope view. 98

Figure 2: Locations of rock glacier inventory features....................................99

Figure 3: Rock glacier areas, as a percent of the HUC12 watersheds that contain them. 100

Figure 4: Statistically significant Getis-Ord $\mathrm{Gi}^{*}$ hot spots for rock glacier percent area at the HUC12 watershed level. 101

Figure 5: Geographic characteristics of Class 1, Class 2 and Class 3 rock glaciers. 102

Figure 6: Geographic and atmospheric characteristics of rock glaciers by NOAA Climate Region. 103

Figure 7: Standardized residuals for the Chapter 2 rock glacier OLS model....104 Figure 8: Standardized residuals for the Chapter 2 rock glacier final GWR model.

Figure 9: The Chapter 2 rock glacier final GWR model allows the coefficients for mean spring dewpoint to vary in sign. 106

Figure 10: The Chapter 2 rock glacier final GWR model allows the coefficients for percent barren land cover to vary in sign.

Figure 11: Locations of distribution centroids for glaciers and rock glaciers ....109 Figure 12: Glacier areas, as a percent of the HUC12 watersheds entirely within the contiguous U.S. that contain them. 110

Figure 13: Rock glacier areas, as a percent of the HUC12 watersheds entirely within the contiguous U.S. that contain them.

Figure 14: Statistically significant Getis-Ord $\mathrm{Gi}^{*}$ hot spots for glacier percent area at the HUC12 watershed level

Figure 15: Statistically significant Getis-Ord $\mathrm{Gi}^{*}$ hot spots for rock glacier percent area at the HUC12 watershed level. 113

Figure 16: Topographic characteristics of glaciers and rock glaciers 114

Figure 17: Topographic and atmospheric characteristics of glaciers and rock glaciers.

Figure 18: Atmospheric characteristics of glaciers and rock glaciers. 116

Figure 19: Standardized residuals for the Chapter 3 glacier OLS model.........117

Figure 20: Standardized residuals for the Chapter 3 glacier final GWR model. 118

Figure 21: The Chapter 3 glacier final GWR model does not allow the coefficients for elevation range to vary in sign.

Figure 22: The Chapter 3 glacier final GWR model does not allow the coefficients for mean fall snowfall to vary in sign....

Figure 23: Standardized residuals for Chapter 3 rock glacier OLS model........121 Figure 24: Standardized residuals for the Chapter 3 rock glacier GWR model. 
Figure 25: The Chapter 3 rock glacier GWR model allows the coefficients for mean spring dewpoint temperature to vary in sign.

Figure 26: The Chapter 3 rock glacier GWR model allows the coefficients for slope standard deviation to vary in sign.

Figure 27: Mean annual precipitation taken from PRISM 1981 - 2010 normals.

Figure 28: Mean annual air temperature taken from PRISM 1981 - 2010 125 normals

Figure 29: Mean annual dewpoint taken from PRISM 1981 - 2010 normals...127 Figure 30: Map of 35 glacier and rock glacier riparian vegetation analysis meltwater stream pairs, with counts for each state.

Figure 31: Representative plan-view DigitalGlobe QuickBird satellite image of a glacier and rock glacier meltwater stream pair.

Figure 32: Box plots illustrating significant differences between meltwater stream riparian vegetation density by growing season....

Figure 33: Box plots illustrating significant differences between meltwater stream riparian vegetation density by growing season 


\section{Chapter 1: Introduction}

Globally, montane environments are warming at an alarming rate. The two most widely appreciated elements of the montane cryosphere are alpine glaciers and perennial snowfields, respectively identified simply as "glaciers" and "snowfields" henceforth. Warming air temperatures and shifts in winter precipitation from snow to rain have reduced depth and duration of winter snowpack in many regions of the contiguous United States. Both glaciers and snowfields, which integrate seasonal changes in snowfall as well as the effects of increasing summer temperatures, are in sharp retreat.

Two lesser known components of the montane cryosphere are rock glaciers and debris-covered glaciers, though presently there are no widely accepted formal definitions of either feature type that can be used to discriminate them for all purposes. Most researchers consider rock glaciers to be flowing bodies of permafrost, composed of generally regular vertical distributions of coarse talus and granular regolith bound by interstitial ice. The vast majority of rock glaciers are primarily periglacial in origin, resulting from precipitation, meltwater or groundwater percolating into entrained coarse glacial debris and freezing. This interstitial ice is insulated from warm air temperatures and high vapor pressure deficits, as well as shielded from direct insolation, by the overlying regolith mantle. Some non zero fraction of the ice internal ice content remains frozen through the summer, with additional ice being incorporated each winter until an 
active rock glacier is formed. Most researchers consider debris-covered glaciers to simply be talus-covered glaciers, retaining discrete ice cores with relatively low internal concentrations of regolith. The surficial talus mantling of debris-covered glaciers is sourced from mass wasting of over-steepened lateral slopes formerly buttressed by the glacier body, but now unsupported and exposed to the elements due to glacial recession. These features are completely indistinguishable from the more traditionally defined rock glaciers through surface analysis, either in the field or based on remotes sensing imagery, and can only begin to be discriminated for more nuanced geomorphic classification through direct coring or ground penetrating radar. While the specific semantics of these two cryospheric feature types are occasionally vigorously debated in peerreviewed literature, the debate is only active within a minuscule fraction of glaciologists.

For most every geomorphological intent, influence, impact and purpose, and absolutely all of our needs, traditionally defined rock glaciers exhibiting a regular mix of ice and regolith through their thickness need not be differentiated from surficially indistinguishable debris covered glaciers with distinct ice cores. We combine the two most popular rock glacier definitions from both the "glacial continuum" and "permafrost creep" schools of thought, group both feature types together, and define all rock glaciers as: "The visible expression of steady-state creep of supersaturated mountain permafrost bodies in unconsolidated material, usually of angular boulders that resemble a small glacier, generally occurring in 
high mountainous terrain, often with ridges, furrows, and sometimes lobes on its surface, having a steep front at the angle of repose". In this research, I cannot and need not discriminate between the two genetic rock glacier types and refer to them all collectively as "rock glaciers". Virtually all examples of both forms of rock glaciers have generally been shaped by a combination of glacial and periglacial forces at some point in their geologically recent history, suggesting that considering them here as a single feature type is a reasonable approach. This dissertation research examines the spatial distribution (Chapter 2), cryospheric context (Chapter 3) and meltwater stream riparian vegetation (Chapter 4) of rock glaciers of the contiguous U.S.

The spatial distribution of glaciers and snowfields of the contiguous U.S. is reasonably well understood, yet continental-scale rock glacier dynamics are poorly understood. The geographic distribution of rock glaciers of the contiguous U.S. and the climatic, topographic, and geologic variables controlling that distribution are unknown. Initial investigation shows that rock glaciers are ubiquitous when compared to glaciers and snowfields, especially at low latitudes and in arid regions. This leads to the questions:

- What is the spatial distribution of rock glaciers of the contiguous U.S.?

- What geographic and climatic factors most affect that spatial distribution?

Once the distribution of rock glaciers is known to the same level of spatial precision as the distributions of glaciers, both cryospheric feature types can be 
systematically compared at multiple scales of analysis. Similarities and differences between the climatic, topographic, and geologic variables controlling the distributions are unknown. This leads to the questions:

- What geographic and climatic factors drive the unique spatial distribution patterns of glaciers and rock glaciers?

- Which of these two cryospheric feature types can be predicatively modeled most accurately from geographic and climatic data?

During identification of rock glaciers to address questions driving Chapter 1 and Chapter 2, anecdotal yet systemic riparian vegetation differences were visually apparent. Rock glacier meltwater stream vegetation appeared considerably more lush than glacier meltwater stream vegetation in virtually every aerial and satellite image considered. This leads to the questions:

- Is the percent cover of riparian vegetation along rock glacier meltwater streams different than that along glacier meltwater streams?

- Is the maximum density of riparian vegetation along rock glacier meltwater streams different than that along glacier meltwater streams?

- Can any observed riparian vegetation pattern differences be well explained by meltwater source type?

These three avenues of research inform at disparate, yet interconnected, spatial scales. By working to answer these questions, and operating under the 
widely held expectation of further alpine warming and glacier recession in the future, I am able to inform a wide range of rapidly expanding alpine cryospheric research, both pure and applied, across the contiguous U.S. and far beyond. 


\section{Chapter 2: Geospatial Inventory, Spatial Distribution Patterns and Geographically Explicit Modeling of Contiguous United States Rock Glaciers}

\subsection{Abstract}

Continental-scale inventories of glaciers are available, but no analogous rock glacier inventories exist. We present the Portland State University Rock Glacier Inventory $(n=10,343)$ for the contiguous United States derived from manual classification of remote sensing imagery, then identify geographic and climatic factors affecting the spatial distribution. While at least one rock glacier is identified in each of the 11 westernmost states, nearly $90 \%$ are found in just five; Colorado $(n=3889)$, Idaho $(n=1723)$, Montana $(n=1780)$, Utah $(n=834)$, and Wyoming $(n=849)$. Mean rock glacier area is estimated at $0.10 \pm 0.002 \mathrm{~km}^{2}$, with total rock glacier area exceeding $1000 \mathrm{~km}^{2}$. Rock glaciers are assigned to a three-class system based on area thresholds and surface characteristics known to correlate with downslope movement. Class 1 features $(n=7052)$ appear highly active, Class 2 features $(n=2416)$ appear intermediately active, and Class 3 features $(n=875)$ appear minimally active. Cumulative rock glacier area, as a percent of the 1523 small watersheds containing them, is modeled using both ordinary least squares and geographically weighted regression. A geographically weighted rock glacier regression model (adjusted $\left.\mathrm{R}^{2}=0.45\right)$ highlights mean spring dewpoint temperature and percent barren land cover as the best 
predictors. This geospatial inventory will allow past rock glacier research findings to be spatially extrapolated, help facilitate further rock glacier research by identifying study sites, and serve as a valuable training set for development of automated rock glacier identification and classification methods applicable to other large regional study areas.

\subsection{Introduction}

The most well-known elements of the montane cryosphere are alpine glaciers and perennial snowfields (simply "glaciers" and "snowfields" hereafter). Less widely known are rock glaciers, flowing bodies of permafrost composed of a matrix of regolith bound and mobilized downslope by interstitial ice (Clark et al. 1998, Berthling 2011a). Virtually all rock glaciers are periglacial in origin, resulting from precipitation, meltwater or groundwater percolating into mechanically weathered debris and freezing (Francou et al. 1999, Berthling 2011b). This interstitial ice is subsequently insulated from warm air temperatures and high atmospheric vapor pressure deficits, as well as shielded from direct solar insolation, by the overlying regolith mantle. Much of this ice remains frozen through the summer melt season, with additional ice being incorporated each winter until a proper rock glacier is formed.

The spatial distributions of glaciers and snowfields of the contiguous U.S. are well understood (Arendt et al. 2015). Conversely, the distribution of rock glaciers of the contiguous U.S. and the geographic and climatic variables controlling that 
distribution are almost wholly uncertain. Lacking the brilliantly reflective surfaces of glaciers and snowfields, which in late summer afford strong spectral contrast with immediately adjacent land cover, rock glaciers are challenging to identify remotely using automated methods, making spatial inventories difficult to compile (Millar and Westfall 2008). Compared to their more widely known glacier and snowfield counterparts, rock glaciers are enigmatic, ambiguously defined, and therefore somewhat contentious land forms (Clark et al. 1998, Berthling 2011b).

In this study we first develop the Portland State University Rock Glacier Inventory (PDXRGI) for the contiguous United States, then identify those geographic and climatic variables most directly affecting the observed spatial distribution. This inventory will help further research define the role of rock glaciers with respect to alpine climatology, ecology, geomorphology, hydrology and engineering. Rock glacier responses to climate shifts are beginning to be understood with equal specificity to the climatic responses of glaciers, allowing past climatic conditions on short (Bodin et al. 2009, Sorg et al. 2015) and long time scales (Konrad et al. 1999, Stenni et al. 2007, Matthews et al. 2013) to be inferred from their present condition and distribution. The PDXRGI will also help advance growing ecological interest in rock glaciers as climate refugia for coldadapted flora and fauna (Caccianiga et al. 2011, Sulejman 2011, Millar et al. 2013b). Previously studied rock glaciers have shown they can control major fractions of local regolith transport (Kaab and Reichmuth 2005, Haeberli et al. 2006). Additionally, rock glacier meltwaters exhibit unique hydrographs 
(Bajewsky and Gardner 1989, Pauritsch et al. 2015) and hydrochemistry signatures (Millar et al. 2013a, Fegel et al. 2016), but also volumetric discharge increases in late summer due to climate change (Caine 2010). From an anthropogenic perspective, rock glaciers represent unique engineering challenges, particularly with regard to catastrophic collapse and debris flow generation (Iribarren and Bodin 2010, Lugon and Stoffel 2010, Bodin et al. 2017), but also opportunities as reservoirs of construction aggregate and water (Burger et al. 1999).

The regional or continental scale impacts of these and other influences cannot be inferred without an accurate rock glacier inventory at the same spatial scale. Smaller scale rock glacier inventories have been completed before (Table 1), but the rock glacier distribution across an area the size of the contiguous U.S. has never before been quantified in a single inventory. Where prior rock glacier inventories have considered study areas measured in dozens, hundreds, or (rarely) thousands of square kilometers, our rock glacier inventory evaluates a study area of over $3,000,000 \mathrm{~km}^{2}$. This study addresses two research questions: 1) What is the spatial distribution of rock glaciers of the contiguous U.S.?, and 2) What geographic and climatic factors most affect that spatial distribution? Answering these two basic questions will inform a wide range of rapidly expanding alpine research, both pure and applied, across the contiguous U.S. and far beyond. 


\subsection{Data and Methods}

\subsubsection{Study Area and Data Sources}

This study evaluated the entire montane contiguous U.S. for evidence of active rock glaciers, though analysis of even the highest peaks along the Atlantic seaboard made immediately apparent there are no extant active rock glaciers east of the Rocky Mountain states. As such, we focus on the 11 westernmost states (AZ, CA, CO, ID, MT, NM, NV, OR, UT, WA, WY). Climatologically, the study area is defined by four zones of the NOAA U.S. Climate Region system (Karl and Koss 1984): the Northwest Climate Region (hereafter "NW region") of ID, OR and WA; the Southwest Climate Region (hereafter "SW region") of AZ, CO, NM and UT; the West Climate Region (hereafter "W region") of CA and NV; and the West North Central Climate Region (hereafter "WNC region") of MT and WY. The major mountain range in each of the four regions is the Cascades, Southern Rockies, Sierra Nevada and Northern Rockies, respectively. To define the watersheds containing rock glaciers we used the USGS NHD HUC12 watershed data set (USGS 2013). These small watersheds (mean area $=92.54 \pm$ $2.13 \mathrm{~km}^{2}$ ) were chosen to bridge approaches taken in previous glacier and rock glacier studies that often focus on small contributing drainage areas immediately upslope of cryospheric features, and the needs and interests of ecologists and hydrologists who often focus on larger areas downslope and downstream of cryospheric features. 
A diverse array of geographic and climatic variables known to affect glacier distributions, and which we hypothesize also affect rock glacier distributions, such as elevation (Hewitt 2011), aspect (Evans 2006), topographic variability (Brown and Rod 1996), insolation (Yang et al. 2010), precipitation (Wang et al. 2017), and air temperature (Sicart et al. 2008) are considered. Where applicable, such as with respect to climatic information, data were initially evaluated at annual, seasonal, and monthly time steps. Elevation data are drawn from the USGS National Elevation Dataset (NED) $1 / 3$ arc-second $(\approx 10 \mathrm{~m}$ ) digital elevation model (USGS 2015), which is also used to calculate derivative topographic variables such as slope, aspect and insolation using Spatial Analyst tools in ArcMap 10.4 (ESRI 2017). Slope and aspect are calculated in degrees, though degree aspect is decomposed to an eastness and northness component to better facilitate statistical analysis (Nussear et al. 2009), and areal solar insolation is calculated in watt-hours per square meter. Climate data, including air temperature and precipitation, are drawn from PRISM 1981 - 2010 climate normals (PRISM 2017), and also used to calculate derivative atmospheric variables such as fraction of precipitation falling as snow and mean vapor pressure deficit using the Raster Calculator tool in ArcMap 10.4. Seasons are defined as: winter (Dec, Jan, Feb), spring (Mar, Apr, May), summer (Jun, July, Aug) and fall (Sep, Oct, Nov). Geologic data are drawn from the Database of the Geologic Map of North America (Garrity and Soller 2009). To our knowledge these data sets presently represent the finest spatial resolutions publicly 
available for the entire contiguous U.S. (Table 2). All analysis and estimation is completed at $95 \%$ or higher confidence levels.

\subsubsection{Rock Glacier Identification}

Based on the well accepted spatial correlation between glaciers, perennial snowfields and rock glaciers, and because most rock glaciers are periglacial features formed overwhelmingly from regolith left by receding glaciers (Zasadni 2007), two geographic information system (GIS) data sets that contain glacier and snowfield features were used to identify initial search locations for the rock glacier inventory. The Randolph Glacier Inventory (RGI) v6.0 (NSIDC, RGI Consortium 2017) and the 2011 National Land Cover Database (NLCD) land cover inventory (Homer et al. 2015) both identify contiguous U.S. glaciers and perennial snowfields. The RGI, while somewhat informative, is derived primarily from maps and aerial photos produced from the 1940s to 1980s that do not accurately represent currently extant glacier areas, thus the more recent NLCD was considerably more useful. Initially, areas immediately adjacent to glacier and snowfield features from both GIS data sets were the focus of our search, but later efforts were less dependent on proximity to these GIS data sets than appraising local topography and freezing levels. Rock glaciers were manually identified using satellite and aerial imagery collected since the late 1990s by focusing on their distinct surface characteristics (Aoyama 2005, Haeberli et al. 2006). These characteristics include ridge and swale surface banding resulting from differential 
internal flow rates, and over-steepened terminal and lateral slopes cemented beyond the angle of repose by interstitial ice. Similar approaches to rock glacier identification focusing on surface topography characteristics identified from aerial and satellite imagery have been commonly applied and well validated in the field by other researchers (Eztelmuller et al. 2007, Janke 2007, Degenhardt 2009, Janke et al. 2015).

We focus our inventory efforts on simply identifying rock glaciers across an expansive study area that, surfically, appear to presently contain appreciable internal ice fractions, and do not need to differentiate features identified based on glacial or periglacial genetic origins to address our two research questions. Like most geomorphic land forms, rock glaciers exhibit a continuum of characteristics and no single universally accepted or applicable definition presently exists (Berthling 2011b). Similarly, there is no consensus regarding the differentiation of rock glaciers from fully mantled debris covered glaciers (Whalley et al. 2014). We follow previous studies that omit features with expansive bare glacial ice in their accumulation zones from consideration, but make no attempt to discriminate rock glaciers from fully mantled debris covered glaciers (Bodin et al 2010, Berthling 2011b, Perucca and Angillieri 2011). The primary distinction between our rock glacier inventory and classification system and other previous rock glacier inventory efforts is that we intentionally attempt to exclude relict rock glaciers by ignoring potential candidate features lacking over-steepened terminal slopes and/or presenting evidence of advanced surficial soil development, such as 
expansive vegetation growth. We combine the two most popular rock glacier definitions from both the "glacial continuum" (Haeberli 1985) and "permafrost creep" (Potter 1972) schools of thought and define rock glaciers as: "The visible expression of steady-state creep of supersaturated mountain permafrost bodies in unconsolidated material, usually of angular boulders that resemble a small glacier, generally occurring in high mountainous terrain, often with ridges, furrows, and sometimes lobes on its surface, having a steep front at the angle of repose".

The two most useful surficial characteristics for our rock glacier identification criteria are ridge and swale flow banding and over-steepened terminal and lateral slopes. Surface flow banding in high alpine environments results exclusively from differential rates of downslope movement at meter-scale and greater. While individual fragments of regolith often travel downslope through common mass wasting processes not requiring or associated with ice, coherent downslope movement of regolith assemblages, at meter-scale and beyond, generally does require ice. Similarly, while common mass wasting processes responsible for individual fragments of regolith traveling downslope result in accumulations at or slightly below the angle or repose, regolith formations observed beyond the angle of repose generally require interstitial ice, a critical element of rock glaciers, to cement them together.

We used Google Earth Pro 7.1.7 and ESRI ArcMap 10.4 software platforms to search for rock glaciers. Google Earth Pro was exceptionally valuable due to 
the combination of high resolution imagery acquired at multiple dates from the early 1990 s to present with easily manipulated three-dimensional surface perspectives. Quick access to multiple images of the same location captured at different times of day, during different seasons, and across multiple years increased identification certainty. Unlike the margins of glaciers and snowfields, rock glacier perimeters generally move no more than a few meters per year at most, meaning that virtually all available satellite and aerial imagery, both relatively recent advents, is potentially useful. Image quality, and thus rock glacier identification and classification utility, is affected by atmospheric conditions like lighting intensity and atmospheric particulate concentrations, and ground conditions such as deep shadow or snow cover can further obscure features of interest. Imagery hosted by Google Earth Pro and used to identify rock glaciers is predominantly sourced from Digital Globe satellite platforms. ArcMap 10.4 was also used for inspecting some satellite imagery, but generally only where Google Earth Pro-hosted image coverage was sparse or unsuitable.

When identifying a candidate rock glacier, plan view images were initially viewed at 1:2000 scale or better with topography exaggerated by $50 \%$. Once suspected ridge and swale flow banding and over-steepened terminal and lateral slopes were identified, image scale was greatly increased. All available clear sky images of of the same scene were then evaluated, and plan views were replaced by oblique views from multiple angles and multiple scales. Surrounding areas were also evaluated for evidence of cryospheric features such as glaciers, 
perennial snowfields and creeping permafrost. Additionally, local elevations were considered to qualitatively verify the plausibility of active cryospheric features with respect to low air temperatures driven by simple atmospheric lapse rates. Once an active rock glacier was confidently identified in 2- 10 unique images, a GIS point was added to the visually approximated centroid.

Understandably, there can be some disagreement between analysts regarding rock glacier classification. To partially address this ambiguity all features identified as rock glaciers were subsequently assigned to one of three classes based on surface characteristics known to correlate with downslope movement (Figure 1). Class 1 rock glaciers are definitely active and exhibit distinct, complex and extensive ridge and swale flow banding, and significantly over-steepened terminal slopes. Class 2 rock glaciers are probably active, exhibit some pronounced ridge and swale flow banding, have distinct marginal slopes and somewhat over-steepened terminal slopes. Class 3 rock glaciers appear to be deflated Class 1 or 2 features, have sparse ridge and swale flow banding and some over-steepened slopes, but are not classic pronival ramparts.

\subsubsection{Statistical Comparisons and Modeling}

To numerically quantify and statistically evaluate rock glacier distributions, each rock glacier identified was manually delineated using Google Earth Pro into a GIS polygon feature. These polygons allowed extraction of information from relevant ancillary GIS data sets, including land cover, climate, and geology at 
rock glacier locations, using ArcMap 10.4. Zonal Statistics tools in the Spatial Analyst extension were used to collate ancillary GIS data with from rock glaciers, as well as the HUC12 watersheds that contain them, into tabular form for statistical analysis. Rock glacier polygons and all ancillary GIS data sets were projected to USGS Albers Equal Area Conic prior to analysis. To define the geographic and climatic variables that drive environmental conditions controlling rock glacier spatial distributions, statistical analysis begins with Tukey's Honestly Significant Difference (HSD) tests to identify statistically significant differences. Given the large and climatologically diverse study area, this simple yet robust nonparametric analysis technique is well suited to comparisons of the skewed distributions expected.

Ordinary least squares multiple regression (OLS) and geographically weighted regression (GWR) techniques were employed to model the percentage of HUC12 watershed area covered by rock glaciers. A key element of GWR is that independent variable coefficients are allowed to vary over space to better incorporate relevant local interactions at different spatial scales. Geographic and ecological thresholds of critical relevance can vary spatially and GWR can identify where independent variable coefficients shift magnitude or sign. We initially considered over 300 possible independent variables, but nearly 200 were discarded from modeling due to very low or statistically insignificant correlations with dependent variables and/or severe violations of OLS assumptions. Geologic data (over 25 variables) were similarly rejected as poor predictors, even after 
being reclassified into a simplified three category (metamorphic, plutonic, sedimentary) system, and also exhibited severe heteroscedasticity. Annual and monthly climate data (over 150 variables) were rejected on the basis of poor predictive power. Topographic, land cover and seasonal climatic data were all retained. All models were calibrated using a spatially representative yet randomly selected $75 \%$ subset of observations, then validated with the remaining $25 \%$ of observations. Both subsets were spatially stratified by NOAA Climate Region and U.S. state. Critically, calibration and validation watershed subsets reveal no statistically significant differences with respect to geographic, climatic or land cover variables considered (Tables $3 \& 4$ ).

For OLS models a forward stepwise approach was used, with candidate models discriminated by adjusted $\mathrm{R}^{2}$ values, Akaike Information Criterion Corrected (AICc) scores, significance level of independent variables, and count of independent variables in accordance with the principle of parsimony. Mallow's Cp scores helped verify the best likely variable counts for models without over fitting, and independent variable multicollinearity was constrained using Variance Inflation Factor and Condition Index thresholds of 5 and 30, respectively. Once OLS models were initially defined, they were refined using GWR, which allows independent variable coefficients to vary across the model domain, revealing any spatial nonstationarity of relevant processes (Chang et al. 2014). For GWR models a backward step-wise approach was used with an adaptive spatial bandwidth kernel based on AICc reduction, again discriminating candidate 
models by adjusted $\mathrm{R}^{2}$ values, AICc scores, significance level of independent variables, and count of independent variables.

Once best OLS and GWR models were identified, standardized residuals were compared to identify not only shifts in overall predictive power, but differences in the degree of residual spatial clustering. Well validated models can be applied across the entire spatial domains they are tuned for without large shifts in predictive power, while models that simply deliver a high overall adjusted $R^{2}$ value can give wildly inaccurate predictions if their residuals are not spatially randomly or widely dispersed. Residual clustering analysis using Moran's I and Getis-Ord Giं statistics, both calculated using inverse-distance squared and rowstandardized relationships to highlight the degree of clustering and identify statistically significant hot spots, further helped identify the best models available (Cliff and Ord 1971, Sen 1976, Tiefelsdorf 2002). A key element of GWR is that independent variable coefficients are allowed to vary over space to better incorporate relevant interactions at multiple spatial scales. Geographic and ecological thresholds of critical relevance often vary spatially, and GWR identifies where independent variable coefficients shift sign.

\subsection{Results}

\subsubsection{Spatial Distribution}

We identified 10,343 rock glaciers (Class $1=7052$, Class $2=2416$, Class 3 = 875) in 1540 HUC12 watersheds across the western U.S. (Figure 2, Table 4). 
While 146 small $\left(<0.01 \mathrm{~km}^{2}\right)$ Class 3 rock glaciers were also confidently identified, following glaciological convention, we omit them from our inventory and analysis (Navarro and Magnusson 2017). The average distance between each rock glacier and its nearest neighbor is $0.69 \pm 0.09 \mathrm{~km}$. The overall rock glacier centroid $(41.5,-110.7)$ is located in the southwest corner of the WNC region (Figure 2). The overall centroids of each of the three rock glacier classes (Class $1=(41.5,-110.6)$, Class $2=(41.7,-111.0)$, Class $3=(41.2,-111.0))$ can be contained by a minimum bounding area circle with a diameter of $57.3 \mathrm{~km}$.

Rock glaciers of the NW region are largest and most densely concentrated in the Sawtooth Mountains of Idaho. In the NW region, we identified 1997 rock glaciers (Class $1=1295$, Class $2=513$, Class $3=189)$ in 397 HUC12 watersheds (Figure 2). The average NW region rock glacier size is $0.07 \pm 0.003$ $\mathrm{km}^{2}$, and the average distance between each NW region rock glacier and its nearest neighbor is $0.99 \pm 0.27 \mathrm{~km}$. The NW region rock glacier centroid (44.9,115.3) is located in Idaho (Figure 2). The NW region centroids of each of the three rock glacier classes (Class $1=(44.7,-114.9)$, Class $2=(45.1,-115.7)$, Class $3=(45.2,-116.0))$ can be contained by a minimum bounding area circle with a diameter of $106.3 \mathrm{~km}$.

Rock glaciers of the SW region are largest and most densely concentrated in the Front Range and San Juan Mountains of Colorado and the Uinta Mountains of Utah. In the SW region, we identified 4870 rock glaciers (Class $1=3291$, Class $2=1133$, Class $3=446$ ) in 545 HUC12 watersheds (Figure 2). The 
average SW region rock glacier size is $0.09 \pm 0.003 \mathrm{~km}^{2}$, and the average distance between each SW region rock glacier and its nearest neighbor is $0.59 \pm$ $0.16 \mathrm{~km}$. The SW region rock glacier centroid $(39.0,-107.4)$ is located in Colorado (Figure 2). The SW region centroids of each of the three rock glacier classes $($ Class $1=(39.0,-107.3)$, Class $2=(39.1,-107.5)$, Class $3=(38.7,-107.4))$ can be contained by a minimum bounding area circle with a diameter of $38.2 \mathrm{~km}$.

Rock glaciers of the $\mathrm{W}$ region are largest and most densely concentrated in the Sierra Nevada of California. In the W region, we identified 817 rock glaciers (Class $1=552$, Class $2=181$, Class $3=84$ ) in 123 HUC12 watersheds (Figure 2). The average $W$ region rock glacier size is $0.12 \pm 0.009 \mathrm{~km}^{2}$, and the average distance between each $\mathrm{W}$ region rock glacier and its nearest neighbor is $0.68 \pm$ $0.15 \mathrm{~km}$. The $\mathrm{W}$ region rock glacier centroid $(37.5,-118.6)$ is located in California (Figure 2). The $\mathrm{W}$ region centroids of each of the three rock glacier classes (Class $1=(37.6,-118.7)$, Class $2=(37.4,-118.6)$, Class $3=(37.8,-118.4))$ can be contained by a minimum bounding area circle with a diameter of $48.0 \mathrm{~km}$.

Rock glaciers of the WNC region are largest and most densely concentrated in the Beartooth Mountains of Montana and the Absaroka Range of Wyoming. In the WNC region, we identified 2659 rock glaciers (Class $1=1914$, Class $2=589$, Class $3=156$ ) in 485 HUC12 watersheds (Figure 2). The average WNC region rock glacier size is $0.11 \pm 0.005 \mathrm{~km}^{2}$, and the average distance between each WNC region rock glacier and its nearest neighbor is $0.79 \pm 0.20 \mathrm{~km}$. The WNC region rock glacier centroid $(45.0,-111.0)$ is located in Montana (Figure 2). The 
WNC region centroids of each of the three rock glacier classes (Class $1=(45.0,-$ 110.9), Class $2=(45.1,-111.2)$, Class $3=(45.2,-111.3))$ can be contained by a minimum bounding area circle with a diameter of $49.5 \mathrm{~km}$.

Rock glacier HUC12 percent area also shows strong positive trends favoring the aforementioned mountain ranges. Considering all HUC12 watersheds, rock glacier percent areas ranged from less than $0.01 \%$ in the NW region to $7.63 \%$ in the SW region (Figure 3). In the NW region, mean rock glacier percent areas were $0.47 \pm 0.07 \%$, in the SW region $0.99 \pm 0.10 \%$, in the $\mathrm{W}$ region $0.91 \pm$ $0.20 \%$, and in the WNC region $0.70 \pm 0.10 \%$. Moran's I and Getis-Ord Gi* analysis shows the highest HUC12 watershed percent area values are clustered into 112 statistically significant hot spots $(90 \%$ confidence $=52$ watersheds, $95 \%$ confidence $=30$ watersheds, $99 \%$ confidence $=30$ watersheds), almost exclusively found in the aforementioned mountain ranges (Figure 4). Compared to the 1411 non-hot spot HUC12 watersheds, these 112 watersheds are on average colder (mean annual air temperature $1.3 \pm 0.3^{\circ} \mathrm{C}$ vs. $3.0 \pm 0.1^{\circ} \mathrm{C}$ ), higher (mean elevation $3014 \pm 74 \mathrm{~m}$ vs. $2496 \pm 29 \mathrm{~m}$ ) and steeper (mean slope $23.0 \pm 0.8^{\circ}$ vs $\left.19.1 \pm 0.3^{\circ}\right)$, differences that are all statistically significant.

Comparing topographic and climatic variables between rock glaciers of all three classes reveals systemic statistically significant differences (Figure 5). With the exception of fraction of precipitation falling as snow, Class 1 rock glaciers are significantly different from at least Class 2 or Class 3 rock glaciers, if not both, in virtually every respect. Additional comparisons similarly reveal statistically 
significant differences between NOAA Climate Region rock glacier populations (Figure 6). These regional differences are most pronounced with respect to rock glacier area, elevation, dewpoint temperature, insolation, vapor pressure deficit, air temperatures, and fraction of precipitation falling as snow.

\subsubsection{OLS and GWR Modeling}

The spatial domain for ordinary least squares (OLS) and geographically weighted regression (GWR) models is a slightly reduced subset of the entire 10,343 feature rock glacier inventory and 1540 HUC12 watersheds that contain them. Thirteen watersheds containing contiguous U.S. rock glaciers extend north across the U.S. border into Canada, and as such have incomplete modeling attribute data. Those 13 watersheds, and the 26 contiguous U.S. rock glaciers totaling $2.35 \mathrm{~km}^{2}$ they contain, are excluded from model calibration and validation. As a consequence of watersheds having been delineated with less spatial precision than the rock glacier polygons, three watersheds contain less than $0.01 \mathrm{~km}^{2}$ of rock glacier area total, and are similarly excluded as these minute fractions represent only small slivers of individual rock glaciers properly situated in immediately adjacent watersheds. The remaining 1523 watersheds (total area $141,026.17 \mathrm{~km}^{2}$ ) and the 10,317 rock glaciers they contain (total area $1006.56 \mathrm{~km}^{2}$ ) are the basis for all modeling (Tables $3 \& 4$ ).

Using a forward stepwise procedure, the best OLS model was selected from a suite of 15 candidate models, yielding an adjusted $R^{2}=0.25$ from four 
independent variables; mean spring dewpoint temperature, percent barren land cover, slope standard deviation, and mean winter air temperature (Table 6 Table 8). Moran's I analysis, using inverse-distance squared and rowstandardized relationships, shows OLS standardized residuals exhibit a statistically significant degree of spatial clustering (Table 9). Getis-Ord Gi* analysis of standardized residuals identified 6 watersheds as statistically significant cold spots and 69 watersheds as statistically significant hot spots with 95\% confidence. Geographically weighted regression techniques, used to refine the OLS model, resulted in the exclusion of slope standard deviation and mean winter air temperature as independent variables. The final GWR model, based on mean spring dewpoint temperature and percent barren land cover, yields a much improved adjusted $R^{2}$ value of 0.45 (Table 6 - Table 8 ). Moran's I analysis shows GWR standardized residuals exhibit markedly decreased spatial clustering compared to OLS standardized residuals (Table 9). Moran's I index is reduced from 0.25 to 0.13 , with a corresponding z-score reduction from 22.72 to 11.44 . Getis-Ord $\mathrm{Gi}^{*}$ analysis of standardized residuals identified 15 watersheds as statistically significant cold spots and 68 watersheds as statistically significant hot spots with $95 \%$ confidence. Compared to OLS model standardized residual performance (Figure 7), GWR standardized residual performance (Figure 8) was improved in 703 HUC12 watersheds. Both GWR model independent variable coefficients, as well as the intercept, switch sign (Table 10). Local significance tests for these coefficient variable sign shifts at the watershed scale, however, 
reveal that only the coefficient sign change for mean spring dewpoint temperature is relevant (Figure 9), while percent barren land cover is uniformly positive or zero (Figure 10).

\subsection{Discussion}

\subsubsection{Spatial Distribution}

At the HUC12 watershed scale, rock glacier spatial distribution patterns appear to be determined in large part by atmospheric conditions and topographic variability, as well as an absence of expansive vegetation. Rock glaciers are found across spatially disparate montane environments, but their distribution unambiguously favors relatively high, arid mountain ranges with sparse vegetation such as the Rockies, Sierra Nevada and Uinta. Rock glacier populations in those regions are denser, and the individual rock glaciers making up those populations are larger and exhibit surficial evidence of higher activity, than those found in humid mountain ranges with copious vegetation. These observations support the notion that rock glaciers can be placed within a cryospheric continuum based on ice fraction, with glaciers and snowfields at the extremely high end, cold desert permafrost at the extremely low end, and rock glaciers representing an intermediate condition, a finding supported by previous research on rock glacier internal ice fractions (Janke et al. 2015).

The completeness and accuracy of the inventory are qualitatively and quantitatively supported by numerous field observations and remote sensing 
classification verification by multiple GIS analysts familiar with the alpine cryosphere generally and rock glaciers specifically. The author personally visited over 50 rock rock glaciers during field campaigns for related research, and over 150 rock glaciers with precise coordinates listed in past peer reviewed research were examined remotely when developing our classification criteria. While developing the inventory, dozens of test areas measuring $500 \mathrm{~km}^{2}$ or greater in all 11 western states were checked by two other well trained GIS analysts familiar with the alpine cryosphere for "missing" rock glaciers not originally identified by the author and none were found. When considering the three-class rock glacier activity classification scheme, a test subset of 60 randomly selected rock glaciers were classified in isolation by five GIS analysts familiar with the alpine cryosphere generally and rock glaciers specifically. Classifications were then compared, yielding no significant differences between analyst interpretations. Class 1 rock glaciers showed a 92\% agreement between analysts, Class 2 rock glaciers an $87 \%$ agreement between analysts, and Class 3 rock glaciers a $79 \%$ agreement between analysts.

As this rock glacier inventory is entirely novel and of unprecedented spatial scale, no analogous previous inventories exist for which to make direct and detailed GIS comparisons to. Smaller regional-scale rock glacier inventories have been compiled in the past, though unfortunately the results of none of these inventories are publicly available as geospatial data sets. Coarse scale comparisons can however be attempted based solely on reported findings and 
figures published in previous studies presenting the aforementioned regional rock glacier inventories. Three such coarse comparisons further bolster the completeness of our rock glacier inventory. Polygons were created using the corner coordinates of low resolution study area maps from peer-reviewed articles highlighting one Colorado rock glacier inventory (Janke 2007) and two California rock glacier inventories (Millar and Westfall 2008, Liu et al. 2013). These polygons are then used to select simple counts of rock glaciers identified in our inventory and compare them to counts of rock glaciers reported in the aforementioned studies. The Colorado inventory reported 28 "active" rock glaciers, the category in that study most similar to our classification criteria, in and around Rocky Mountain National Park, while we identified 29 rock glaciers in roughly the same area. The 2008 California study reported 184 rock glaciers in the central Sierra Nevada, but used a far more inclusive "rock-ice feature" definition than our rigorous active rock glacier classification criteria that deliberately includes relict rock glaciers, while we identified 116 rock glaciers in roughly the same area. The 2013 California study reported 67 "active" rock glaciers, a subset of features identified in the 2008 study, while we identified 88 rock glaciers in roughly the same study area. These comparisons are informative, but not necessary conclusive, as all three studies cited used poorly defined study areas, with no actual boundaries shown in the simple rectangular study area maps presented. 


\subsubsection{OLS and GWR Modeling}

The GWR model shows mean spring dewpoint temperatures are negatively correlated with rock glacier percent area in $84 \%$ of the HUC12 watersheds modeled, with the notable exception of the western slope of the Southern Rocky Mountains in Colorado (Figure 9). This area approximates the northeastern extent of the North American Monsoon, a dynamic intrannual precipitation pattern quite different than that experienced by the majority of $\mathrm{HUC12}$ watersheds containing rock glaciers. During the late spring this area of Colorado is influenced by southwesterly migration of a subtropical ridge of high pressure and generally lower humidity, subsequently resulting in a decrease in mean spring dewpoint temperatures. Fundamentally, however, it is crucial to recognize that the actual observed mean spring dewpoint temperatures in $99.67 \%$ of all watersheds considered are negative values, such that negative coefficients actually predict an increase in rock glacier percent areas. Low mean spring dewpoint temperatures imply a gradual onset of the local melt season. Slowly melting seasonal snow is more likely to percolate into entrained regolith and freeze than rapidly melting seasonal snow. The GWR model shows that percent barren land cover is positively correlated with rock glacier percent area in $96 \%$ of the HUC12 watersheds modeled, with locally significant predictors observed virtually everywhere except the Cascade Mountains and Northern Rockies (Figure 10). This finding accords well with the fact that active rock glaciers cannot be covered 
with expansive surface vegetation due to their constant downslope movement and unstable regolith surfaces which retards most soil development processes.

\subsection{Conclusions}

We present the largest single geospatial rock glacier inventory ever completed, a powerful tool informing a wide range of research and management applications. Rock glaciers are found to be a surprisingly widely distributed element of the alpine cryosphere, favoring high elevation, relatively arid mountain ranges of the contiguous U.S. When trying to understand the geographic and climatic factors most affecting rock glacier distribution, GWR modeling leads to more informative, representative and parsimonious predictions than OLS modeling. Results from both OLS and GWR modeling show that rock glacier geographic distributions at the HUC12 watershed level are mediated to a considerable degree by air temperatures and land cover patterns. Coefficients relating to winter or spring weather and either barren or snow/ice land cover were initially identified in all candidate OLS models due to their significance as predictors. The final GWR model retains only mean spring dewpoint temperature and percent barren land cover, discarding slope standard deviation and mean winter temperature from the best OLS model, yet provides over twice the predictive power. Additionally, standardized residual clustering is substantially reduced. 
Despite their ubiquity, rock glaciers remain an under-studied and underappreciated element of the alpine cryosphere (Duguay et al. 2015). The deeper understanding of why rock glaciers form and persist where they do provided by this inventory and modeling will aid ongoing refinement and future implementation of truly automated rock glacier detection methods. The ability to quickly, accurately and objectively identify rock glaciers from presently available remote sensing imagery, without relying on skilled visual image analysts or needing to address the inevitable interpretation disagreements between those analysts, would be an invaluable tool for climatologists, ecologists, water resource managers and many others (Brenning 2009). 


\section{Chapter 3: Comparative Analysis of Contiguous United States Glacier and Rock Glacier Spatial Distribution Patterns}

\subsection{Abstract}

Glaciers and rock glaciers represent two unique expressions of the alpine cryosphere. We compare a novel GIS inventory of contiguous United States rock glaciers $(n=10,343)$ to an existing inventory of contiguous United States glaciers $(n=853)$, identifying geographic and climatic factors affecting the distinct spatial distributions observed. Glaciers are most concentrated in relatively humid mountain ranges, while rock glaciers are most concentrated in relatively arid mountain ranges. Mean glacier area $\left(0.60 \pm 0.073 \mathrm{~km}^{2}\right)$ is significantly greater than mean rock glacier area $\left(0.10 \pm 0.002 \mathrm{~km}^{2}\right)$, though total glacier area $(507.70$ $\left.\mathrm{km}^{2}\right)$ is much lower than total rock glacier area $\left(1008.91 \mathrm{~km}^{2}\right)$. Glacier and rock glacier areas, as a percent of small watersheds (mean area $=92.54 \pm 2.13 \mathrm{~km}^{2}$ ) containing them, are modeled using both ordinary least squares and geographically weighted regression. Glacier percent area geographically weighted regression modeling yields an adjusted $R^{2}$ value of 0.55 , while rock glacier percent area geographically weighted regression modeling yields an adjusted $R^{2}$ value of 0.42 . Glacier percent area is best explained by elevation range and mean fall snowfall, while rock glacier percent area is best explained by mean spring dewpoint temperature and slope standard deviation. This study shows that while the spatial distributions of glaciers and rock glaciers are both 
generally influenced by a combination of geographic and climatic variables, the specific forcings and local magnitudes are distinct for each cryospheric feature type.

\subsection{Introduction}

Glacier spatial distributions are widely accepted as indicators of alpine climate since their formation is dependent on snowfall accumulation and ablation terms integral to defining local and regional climatic regimes (Hock et al. 2002). Glaciers are dependent on snow persistence sufficient at decadal and longer timescales to form multiyear ice thick enough $(\approx 10 \mathrm{~m}$ depending on local slope, Cuffey and Paterson 2010) to generate basal shear stresses high enough to allow plastic deformation and downslope movement under its own weight. Glaciers respond to both long term systemic climate shifts, as well short term extreme climatic variability (Harris et al. 2009). Glaciers are especially useful for inferring climate dynamics at high elevations and latitudes (Dyurgerov and Meier 2000), areas that are still poorly instrumented and infrequently visited, yet are known to currently be experiencing accelerated warming when compared to lower elevations and latitudes (Dyurgerov and Meier 2000).

While glaciers respond to climatic perturbations on decadal and annual timescales, rock glaciers respond much more slowly, offering a geomorphic lens through which to view alpine climate shifts across century and millennium time timescales (Humlum 1998, Konrad et al. 1999, Keller-Pirklbauer et al. 2007). 
Rock glacier climatic responses are at once constrained by, and made more useful for climatic reconstructions, by the facts that they cannot completely melt away due to their regolith fraction and are less susceptible to short term extreme climatic variability (Bodin et al. 2009). Unlike glaciers, which obliterate evidence of each past recession if and when they advance again due to the continuous subglacial mechanical weathering and subsequent ongoing formation of terminal moraines, rock glaciers undergo cycles of advance and stagnation, forming multilobate and layered expressions. Past climatic conditions can be inferred from rock glaciers in a variety of ways, including analysis of ice samples from coring (Clark et al. 1996), as well as lichenometric (Konrad and Clark 1998) and Schmidt-hammer surface dating methods (Rode and Keller-Pirklbauer 2011, Klapyta 2013).

It is well known that individual rock glacier locations are closely associated with past glaciation (Francou et al. 1999, Berthling 2011), but geographic and climatic relationships at regional scales between rock glacier distributions and extant glaciers is uncertain. To bolster the utility of both cryospheric feature types as indicators of past, present and future climate, we compare their spatial distributions across the contiguous U.S. Such a comparison is only recently viable, made possible by the completion of the Portland State University Rock Glacier Inventory (PDXRGI), the world's largest rock glacier inventory to date (Johnson et al. 2018, in preparation). In many alpine regions, glaciers are rapidly shrinking, often retreating and transitioning into snowfields before disappearing 
completely (Basagic and Fountain 2011, Cheng et al. 2016, Drolon et al. 2016).

In these areas particularly, rock glaciers may become ever more valuable climatic indicators. Understanding the relationships among these two cryospheric feature types now, in regions where both are currently extant, is imperative to fully comprehending climate records plausibly available through further study of rock glaciers.

In this study we answer two main research questions: 1) What geographic and climatic factors drive the unique spatial distribution patterns of glaciers and rock glaciers?, and 2) Which of these two cryospheric feature types can be predicatively modeled most accurately from geographic and climatic data?

\subsection{Data and Methods}

\subsubsection{Study Area and Data Sources}

All extant contiguous U.S. glaciers and rock glaciers are found within the 11 westernmost United States (hereafter "WUS"). The NOAA U.S. climate region system, which breaks the entire contiguous U.S. into nine climatologically consistent zones, is employed as the coarsest spatial unit of analysis in this study (Karl and Koss 1984). The WUS study area is comprised of four climate zones of the NOAA climate region system. The Northwest Climate Region (hereafter "NW region") of ID, OR and WA; the Southwest Climate Region (hereafter "SW region") of AZ, CO, NM and UT; the West Climate Region 
(hereafter "W region") of CA and NV; and the West North Central Climate Region (hereafter "WNC region") of MT and WY. The major mountain range in each of the four regions is the Cascades, Southern Rockies, Sierra Nevada and Northern Rockies, respectively. To define the watersheds containing rock glaciers we used the USGS NHD HUC12 watershed data set (USGS 2013). These small watersheds (mean area $=92.54 \pm 2.13 \mathrm{~km}^{2}$ ) were chosen to bridge approaches taken in previous glacier and rock glacier studies that often focus on small contributing drainage areas immediately upslope of cryospheric features, and the needs and interests of ecologists and hydrologists who often focus on larger areas downslope and downstream of cryospheric features.

A diverse array of geographic and climatic variables known to affect glacier distributions, and which we hypothesize also affect rock glacier distributions, such as elevation (Hewitt 2011), aspect (Evans 2006), topographic variability (Brown and Rod 1996), insolation (Yang et al. 2010), precipitation (Wang et al. 2017), and air temperature (Sicart et al. 2008) are considered. Elevation data are drawn from the USGS National Elevation Dataset (NED) $1 / 3$ arc-second $(\approx 10 \mathrm{~m})$ digital elevation model (USGS 2015), which is also used to calculate derivative topographic variables such as slope, aspect and insolation using Spatial Analyst tools in ArcMap 10.4 (ESRI 2017). Slope and aspect are calculated in degrees, though degree aspect is decomposed to an eastness and northness component to better facilitate statistical analysis (Nussear et al. 2009), and areal solar insolation is calculated in watt-hours per square meter. Climate data, including air 
temperature and precipitation, are drawn from PRISM 1981 - 2010 climate normals (PRISM 2017), and also used to calculate derivative atmospheric variables such as fraction of precipitation falling as snow and mean vapor pressure deficit using the Raster Calculator tool in ArcMap 10.4. Seasons are defined as: winter (Dec, Jan, Feb), spring (Mar, Apr, May), summer (Jun, July, Aug) and fall (Sep, Oct, Nov). Geologic data are drawn from the Database of the Geologic Map of North America (Garrity and Soller 2009). To our knowledge these data sets presently represent the finest spatial resolutions publicly available for the entire contiguous U.S. (Table 2). All analysis and estimation is completed at $95 \%$ or higher confidence levels.

Rock glaciers considered are derived from the Portland State University Rock Glacier Inventory (PDXRGI) a novel geospatial inventory compiled by us and recently made publicly available (Johnson et al. 2018, in preparation, website hosting data to be determined). Glaciers considered are derived from the Randolph Glacier Inventory (RGI) v6.0 (NSIDC, RGI Consortium 2017). To identify only relevant, and indeed extant, glaciers, all RGI features with an area < $0.01 \mathrm{~km}^{2}$ were omitted from consideration following glaciological convention (Navarro and Magnusson 2017). Visual inspection of 500 such randomly selected features using recent satellite imagery hosted via Google Earth revealed that more than $85 \%$ of them were completely absent. To determine which of the remaining 5024 features are glaciers and not perennial snowfields, a two step process was employed. 
Following glaciological theory commonly accepted and widely used in textbooks, the basal shear stress of each feature was estimated using the equation $\mathrm{Tb}=\rho g h \sin (\alpha)$, where $\mathrm{Tb}$ is basal shear $(\mathrm{Pa}), \mathrm{p}$ is the density of glacial ice $\left(900 \mathrm{~kg}^{*} \mathrm{~m}^{-3}\right), \mathrm{g}$ is gravitational acceleration $\left(9.8 \mathrm{~m}^{*} \mathrm{~s}^{-1}\right), \mathrm{h}$ is ice thickness, and $\alpha$ is surface slope (Cuffey and Paterson 2010). Surface slope is readily extracted from digital elevation models, and glacier thickness $(h)$ can be estimated from surface area following methods developed in studies of glaciers around the globe (Chen and Ohmura 1990). Following Cuffey and Paterson (2010), a basal shear stress threshold sufficient for plastic deformation of ice (10,000 Pa) was applied to all features, with those above being temporarily classified as glaciers and those below being temporarily classified as snowfields.

To verify these temporary classifications, all features $\geq 0.10 \mathrm{~km}^{2}$ initially classified as snowfields were visually inspected using multiple satellite images for each feature, as were all features $\leq 0.10 \mathrm{~km}^{2}$ initially classified as glaciers. Features completely absent in one or more satellite images were omitted from further analysis. Since a critical element of the definition of a glacier is ice moving downslope under its own weight, where exposure of a blue glacial ice surface and/or surficial evidence of movement such as crevasses were absent from a feature initially classified as a glacier, the feature was reclassified as a snowfield and omitted from further consideration. This results in a data set of 853 glaciers available for comparison to the 10,343 rock glaciers identified in our novel 2018 contiguous U.S. rock glacier inventory. 


\subsubsection{Statistical Comparisons and Modeling}

Analysis of the unique geographic and climatic variables driving glacier and rock glacier spatial distributions begins with Wilcoxon signed-rank tests to identify statistically significant differences in ancillary GIS data extracted for each cryospheric feature type. Particular attention was paid to those variables already understood to be driving glacier spatial distributions, namely air temperature and precipitation patterns (Mote 2005, Barnett et al. 2008). Given the large and climatologically diverse study area, this robust nonparametric analysis technique is well suited to comparisons of the skewed distributions observed. While a simple analytical technique, Wilcoxon signed-rank tests quickly illuminate relevant differences between the physical environments these two different cryospheric feature types occupy.

The spatial domains for OLS and GWR models reflect slightly reduced subsets of the complete glacier and rock glacier inventories. Watersheds that extend north across the U.S. border into Canada, and as such offer incomplete ancillary independent variable modeling attribute data, were excluded. Similarly, watersheds containing $<0.001 \mathrm{~km}^{2}$ total of glacier or rock glacier area were also excluded, as these minute fractions represent only small slivers of individual cryospheric feature polygons properly situated in immediately adjacent watersheds. These exclusions lead to 1728 HUC12 watersheds (total area 
$158,997.84 \mathrm{~km}^{2}$ ) containing 819 glaciers (total area $496.38 \mathrm{~km}^{2}$ ) and 10,317 rock glaciers (total area $1006.57 \mathrm{~km}^{2}$ ) as the basis for all regression analysis.

Ordinary least squares multiple regression (OLS) and geographically weighted regression (GWR) techniques were employed to explain the variation in the percentage of HUC12 watershed area covered by each cryospheric feature type. We initially considered over 300 possible independent variables, but nearly 200 were discarded from modeling due to very low or statistically insignificant correlations with dependent variables and/or severe violations of OLS assumptions. All models were calibrated using a spatially representative yet randomly selected $75 \%$ subset of observations, then validated with the remaining $25 \%$ of observations. Both subsets were spatially stratified by NOAA Climate Region and U.S. state. Critically, calibration and validation watershed subsets reveal no statistically significant differences with respect to geographic, climatic or land cover variables considered (Tables 12 \& 13). A forward stepwise approach was used to first build OLS models for each cryospheric feature type, with candidate models discriminated by adjusted $R^{2}$ values, Akaike Information Criterion Corrected (AICc) scores, significance level of independent variables, and count of independent variables in accordance with the principle of parsimony. Mallow's $\mathrm{Cp}$ scores helped verify the best likely variable counts for models without over fitting, and independent variable multicollinearity was constrained using Variance Inflation Factor and Condition Index thresholds of 5 and 30, respectively. Once OLS models were initially defined, they were refined 
using GWR, which allows independent variable coefficients to vary across the model domain, revealing any spatial nonstationarity of relevant processes (Chang et al. 2014). For GWR models a backward step-wise approach was used with an adaptive spatial bandwidth kernel based on AICc reduction, again discriminating candidate models by adjusted $R^{2}$ values, AICc scores, significance level of independent variables, and count of independent variables.

Once best OLS and GWR models were identified, standardized residuals were compared to identify not only shifts in overall predictive power, but differences in the degree of residual spatial clustering. Well validated models can be applied across the entire spatial domains they are tuned for without large shifts in predictive power, while models that simply deliver a high overall adjusted $R^{2}$ value can give wildly inaccurate predictions if their residuals are not spatially randomly or widely dispersed. Residual clustering analysis using Moran's I and Getis-Ord Gi ${ }^{*}$ statistics, both calculated using inverse-distance squared and rowstandardized relationships to highlight the degree of clustering and identify statistically significant hot spots, further helped identify the best models available (Cliff and Ord 1971, Sen 1976, Tiefelsdorf 2002). A key element of GWR is that independent variable coefficients are allowed to vary over space to better incorporate relevant interactions at multiple spatial scales. Geographic and ecological thresholds of critical relevance often vary spatially, and GWR identifies where independent variable coefficients shift sign. 


\subsection{Results}

\subsubsection{Spatial Distributions}

The NW region was found to contain 511 glaciers and 1997 rock glaciers, the SW region 7 glaciers and 4870 rock glaciers, the W region 113 glaciers and 817 rock glaciers, and the WNC region 222 glaciers and 2659 rock glaciers. Considering all features, glaciers are separated from other glaciers on average by $1.4 \pm 0.9 \mathrm{~km}$, rock glaciers are separated from other rock glaciers on average by $0.7 \pm 0.1 \mathrm{~km}$, and glaciers and rock glaciers are separated on average by $110.7 \pm 2.0 \mathrm{~km}$. In the NW region glaciers are separated from other glaciers on average by $2.2 \pm 2.0 \mathrm{~km}$, rock glaciers are separated from other rock glaciers on average by $1.3 \pm 0.3 \mathrm{~km}$ and glaciers and rock glaciers are separated on average by $82.0 \pm 2.5 \mathrm{~km}$. In the SW region glaciers are separated from other glaciers on average by $5.0 \pm 4.0 \mathrm{~km}$, rock glaciers are separated from other rock glaciers on average by $1.0 \pm 0.2 \mathrm{~km}$ and glaciers and rock glaciers are separated on average by $183.5 \pm 3.8 \mathrm{~km}$. In the $\mathrm{W}$ region glaciers are separated from other glaciers on average by $1.9 \pm 0.4 \mathrm{~km}$, rock glaciers are separated from other rock glaciers on average by $1.1 \pm 0.2 \mathrm{~km}$ and glaciers and rock glaciers are separated on average by $30.2 \pm 6.8 \mathrm{~km}$. In the WNC region glaciers are separated from other glaciers on average by $3.1 \pm 1.8 \mathrm{~km}$, rock glaciers are separated from other rock glaciers on average by $1.2 \pm 0.2 \mathrm{~km}$ and glaciers and rock glaciers are separated on average by $59.5 \pm 2.4 \mathrm{~km}$. 
Spatial distributions are most simply quantified by central tendencies, and the centroids of glacier and rock glacier distributions, both for the complete data sets and at regional scales, are quite distinct. The overall glacier centroid (45.9, $-118.5)$ is located in the NW region, while the overall rock glacier centroid (41.5,110.7 ) is located $796 \mathrm{~km}$ southwest in the WNC region (Figure 11). Individually considering the four NOAA climate regions hosting these two cryospheric feature types shows very different distribution patterns. At regional scales, the spatial distribution patterns of the two cryospheric feature types are most homogeneous in the $\mathrm{W}$ region, with both feature type centroids being separated by $51 \mathrm{~km}$, and most heterogeneous in the NW region, with both feature type centroids being separated by $590 \mathrm{~km}$. Centroid analysis, however, does not take into account the disparate counts of glaciers and rock glaciers observed in each region.

Of the four regions considered, the NW region hosts by far the most glaciers and is also the most varied with respect to spatial distributions. Glaciers of the NW region are found predominantly in Washington state, while rock glaciers are found predominantly in Idaho, following the sharp precipitation gradient observed between the humid Cascade Mountains and arid Sawtooth Mountains. The three other regions are all overwhelmingly dominated by rock glaciers, but have far more homogeneous spatial distribution patterns for both cryospheric feature types. This likely results from the much more even precipitation observed in these regions. In the SW region, all of the very few glaciers are found in the Front Range of Colorado, while rock glaciers are found across all mountain ranges. In 
the $\mathrm{W}$ region most glaciers are found in the Northern Sierra Nevada and Southern Cascade Ranges of California, while rock glaciers are found all across the Sierra Nevada. In the WNC region virtually all features of both types are found in either the Beartooth and Lewis Ranges of Montana or the Wind River Range of Wyoming.

Considering all HUC12 watersheds, glacier percent areas ranged from less than $0.01 \%$ in the WNC region to $20.99 \%$ in the NW region (Figure 12), while rock glacier HUC12 percent areas ranged from less than $0.01 \%$ in the NW region to $7.63 \%$ in the SW region (Figure 13). In the NW region, mean glacier percent areas were $3.10 \pm 0.65 \%$ and mean rock glacier percent areas were $0.47 \pm$ $0.07 \%$, in the SW region areas were respectively $0.18 \pm 0.10 \%$ and $0.99 \pm$ $0.10 \%$, in the $\mathrm{W}$ region areas were respectively $0.50 \pm 0.22 \%$ and $0.91 \pm 0.20 \%$, and in the WNC region areas were respectively $1.07 \pm 0.42 \%$ and $0.70 \pm 0.10 \%$. Moran's I analysis showed both cryospheric feature type HUC12 percent areas were significantly clustered. Similarly, Getis-Ord Gi* analysis showed both also exhibited statistically significant hot spots (Figures $14 \& 15$ ). Glaciers were found to be largest and most densely concentrated in the Cascade Mountains of Washington and the Wind River Range of Wyoming. Rock glaciers were found to be largest and most densely concentrated in the in the Sierra Nevada of California, the Front Range and San Juan Mountains of Colorado, the Sawtooth Mountains of Idaho, the Beartooth Mountains of Montana, the Uinta Mountains of Utah, and the Absaroka Range of Wyoming. 
Wilcoxon signed-rank tests identify statistically significant differences in virtually all ancillary GIS data extracted for each cryospheric feature type, both for the complete data sets as well as NOAA climate region subsets (Figure 16 Figure 18). Generally, rock glaciers are smaller, have shallower slopes, are less easterly facing, receive less precipitation overall and a lower fraction of precipitation as snow, and endure much wider air temperature ranges than glaciers. Regional analysis showed that glaciers and rock glaciers are most similar in the SW region, but this finding is likely a statistical artifact of there being so few glaciers in the region for comparison. Considering the three other regions, hosting far more glaciers for analysis, showed that glaciers and rock glaciers are most similar in the $\mathrm{W}$ region and most dissimilar in the NW region.

\subsubsection{OLS and GWR Modeling}

For glaciers, the best OLS model relies on three independent variables (elevation range, mean fall snowfall, max summer vapor pressure deficit) to achieve an adjusted $\mathrm{R}^{2}$ value of 0.47 (Table 14). Moran's I analysis shows OLS standardized residuals (Figure 19) are significantly clustered ( $p$-value $<0.001$, Table 15). This model is considerably improved using GWR, resulting in a model that relies on two independent variables (elevation range, mean fall snowfall) to achieve an adjusted $R^{2}$ value of 0.55 (Table 14). Moran's I analysis shows GWR standardized residuals (Figure 20) are randomly distributed ( $p$-value $=0.61$, Table 15) and markedly improved relative to OLS standardized residuals. The 
model coefficients for both elevation range and mean fall snowfall are allowed switch sign. Local significance tests for these coefficient variable sign shifts at the watershed scale, however, reveal that neither are statistically relevant and both coefficients are uniformly positive and highest in the Cascade Mountains (Figures $21 \& 22)$.

For rock glaciers, the best OLS model relies on two independent variables (mean spring dewpoint temperature, slope standard deviation) to achieve an adjusted $R^{2}$ value of 0.21 (Table 16). Moran's I analysis shows OLS standardized residuals (Figure 23 ) are significantly clustered ( $p$-value $<0.001$, Table 17$)$. This model is considerably improved using GWR, resulting in a model that still relies on the same two independent variables, but achieves an adjusted $R^{2}$ value of 0.42 (Table 16). Moran's I analysis shows GWR standardized residuals (Figure 24) are still significantly clustered, yet considerably less so than OLS standardized residuals (Table 17). The model coefficients for both mean spring dewpoint temperature and slope standard deviation are allowed to spatially vary in sign, however when considering only locally significant coefficients no sign shifts are apparent. The coefficient for mean spring dewpoint temperature is generally negative, while the coefficient for slope standard deviation is generally positive (Figures $25 \& 26$ ). 


\subsection{Discussion}

\subsubsection{Spatial Distributions}

Previous modeling has shown atmospheric variables, primarily air temperature and precipitation factors, to be the predominant controls on glacier geographic distributions (Abermann et al. 2011). Our centroid analysis of spatial distribution patterns for points to similar forcings, as the two overall feature centroids span a northwest-southwest distance of nearly $800 \mathrm{~km}$. This alignment roughly follows annual precipitation (Figure 27), maximum air temperature (Figure 28), and mean dewpoint (Figure 29) gradients at the continental scale. The NW region is the coolest and wettest and the SW region is the warmest and driest. The NW region exhibits far and away the densest glacier distributions, implying glaciers are heavily dependent on high precipitation values and cool temperatures. The SW region exhibits far and away the densest rock glacier distributions, implying rock glaciers are much less dependent on high precipitation values and cool temperatures, and can readily persist in warm, dry climate regimes.

\subsubsection{GWR Modeling}

For both glaciers and rock glaciers, OLS models were substantially improved by refining them with GWR techniques. In both cases adjusted $R^{2}$ values increased, AICc scores decreased, and standardized residual clustering was reduced. For glaciers, one independent variable was dropped, resulting in a more 
parsimonious model. Glacier and rock glacier distributions are both shown to be mediated by geographic and climatic variables. Independent variable coefficient magnitude shifts and sign changes shown by GWR modeling illuminate unique geographic and climatic thresholds relevant to the spatial distributions of each cryospheric feature type between different mountain ranges.

For glaciers, which are almost exclusively found in the NW region, elevation range is positively associated there. The overwhelming majority of contiguous U.S. glaciers, and all large glaciers, are found in the Cascade Mountains of Washington, a mountain range dominated by stratovolcanoes which are generally drained by HUC12 watersheds that have relatively large elevation ranges (mean elevation range $=2218 \pm 101 \mathrm{~m}$ ). In this region $\mathrm{HIC} 12$ watershed with large elevation range values are also the watersheds with the highest overall elevations, lowest air temperatures and largest snowfall accumulations. The only other areas of the contiguous U.S. that could reasonably be considered heavily glaciated are the Northern Rockies of Montana and the Teton and Wind River Ranges of Wyoming, both of which have statistically insignificant elevation range coefficients near or slightly below zero, but are all drained by HUC12 watersheds that have relatively small elevation ranges (mean elevation range $=1725 \pm 83 \mathrm{~m}$ ) compared to the Cascades. The coefficient for mean fall snowfall Likely reflects the importance of early season snowfall to the formation and persistence of glaciers. Early season snowfall is the most likely to be compacted and transform into ice, which is more likely to persist interannually than late season snow that 
does not undergo metamorphosis into ice. The coefficient is positive in every HUC12 watershed except one in Idaho. However, this single exception shows only a slightly negative coefficient $(-0.000018)$, exhibits a poor local $R^{2}$ (0.003476) and can be considered an insignificant statistical anomaly, likely the result of the very few local neighbors the GWR model is based on there.

For rock glaciers, the most significant predictor is mean spring dewpoint temperature, which is almost universally strongly negatively associated. Low mean spring dewpoint temperatures imply a gradual onset of the local melt season. Slowly melting seasonal snow is more likely to percolate into entrained regolith and freeze than rapidly melting seasonal snow. Fundamentally, however, it is crucial to recognize that the actual observed mean spring dewpoint temperatures in $99.67 \%$ of all watersheds considered are negative values, such that negative coefficients actually predict an increase in rock glacier percent areas. The very few exceptions are generally areas subject to strong rain shadow effects, but even in those locations the positive mean spring dewpoint temperature associations are very weak, and the coefficient is statistically insignificant at the local level. A more complex relationship, though one that relates to a much less statistically significant predictor of rock glacier spatial distributions than mean spring dewpoint temperature, are slope standard deviation coefficients that change in sign. While generally a positive association, and strongly positive at that where rock glacier spatial distributions are the most dense, slope standard deviation is weakly negatively associated in the Cascade 
Mountains of Washington, Northern Rockies of Montana and a few watersheds subject to strong rain shadow effects in the Sawtooth Mountains of Idaho and San Juan Mountains in Colorado. As with the coefficient sign shits observed for mean spring dewpoint temperature associations, and the coefficient sign shits observed for slope standard deviation coefficients are statistically insignificant at the local level. Watersheds with high slope standard deviations have more areas for now to accumulate through wind redeposition and avalanches, likely leading to small scale snow accumulations greater than that which directly falls.

Additionally, high slope standard deviations will lead to slower snowmelt runoff evacuation at the watershed scale, increasing the likelihood that meltwater will percolate into entrained regolith at high elevations and remain there long enough to refreeze during the next winter, helping to form and maintain rock glaciers.

\subsection{Conclusions}

Glacier and rock glacier distributions both appear to be controlled by a mix of geographic and climatic factors. Glacier distributions seem to be dependent on early season snowfall and high elevations, conceptually both factors that can be understood to increase annual snowfall and the probability that snow accumulations will metamorphose in to ice. Rock glacier distributions seem to be dependent on gradual melt season onsets and watershed slope variability, conceptually both factors that can be understood to increase the probability that snowmelt will percolate into and remain entrained within high elevation talus and 
regolith deposits long enough to refreeze. While model predictions for glaciers are the most accurate, this likely results from their highly concentrated spatial distributions relative to rock glaciers. Nearly $60 \%$ of the glaciers of the contiguous U.S., accounting for fully $79 \%$ of the contiguous U.S. glacier area, are found in the Cascade Mountains of the NW region. The WNC region hosts another $26 \%$ of the glaciers of the contiguous U.S., accounting for an additional $16 \%$ of the contiguous U.S. glacier area. Model predictions for rock glaciers show the greatest improvement from incorporating GWR techniques, likely due to their large number and wide distributions, which allow GWR models many close neighbors to base local coefficients on. Model predictions for glaciers also show improvement from incorporating GWR techniques, but in general are likely impaired by the use of somewhat outdated polygons, which greatly inflate glacier areas.

This study can and should be revisited as glacier inventories are updated. We sourced our glacier polygons from the RGI for the contiguous U.S., which is derived primarily from maps and aerial photos produced from the 1940s to 1980 s that do not accurately represent currently extant features and greatly inflate individual glacier areas and widen spatial distributions. A cursory analysis of these glacier polygons shows poor spatial concordance with recent multispectrally derived snow and ice land cover classifications, such as the 2011 NLCD. Additionally, our findings could be used in conjunction with studies that estimated rock glacier internal ice fractions that correlate extremely well with the 
surface topography characteristics used to categorize rock glaciers by relative activity level to better understand rock glaciers in the context of regional hydrology. Though we didn't use the variable in this study, the PDXRGI assigns all rock glaciers to three classes that could readily be used to estimate individual rock glacier water contents, which could then be summed by region and compared to glacier water contents following methods widely employed already in South America studies. Finally, while the models we present here are tuned for the 11 westernmost contiguous U.S. states, the large feature counts and heterogeneous study area topographic and climatic conditions imply modeling could be revisited with smaller scale, more topographically and climatically homogeneous subsets, to develop models for application in other regions, or possibly even Mars. 


\section{Chapter 4: Comparative Analysis of Contiguous United States Glacier and Rock Glacier Meltwater Stream Riparian Vegetation}

\subsection{Abstract}

A growing body of research implies rock glaciers are a unique component of the alpine cryosphere. We compare riparian vegetation along meltwater streams draining glaciers and rock glaciers of the contiguous United States to determine if significant differences exist with respect to vegetation cover and vegetation density. Initial $500 \mathrm{~m}$ long meltwater stream reaches emanating from a total of 35 pairs of collocated glaciers and rock glaciers were delineated, allowing estimation of riparian vegetation cover from the 2011 National Land Cover Database and riparian vegetation density from 2013 - 2018 Landsat 8 multispectral imagery. Stream reaches selected showed virtually no statistically significant differences with respect to topographic and climatic variables widely understood to be associated with vegetation growth and persistence, yet paired t-tests showed that rock glacier meltwater stream riparian vegetation cover (mean cover $=86.2 \% \pm$ $9.3 \%$ ) and riparian vegetation density (mean NDVI $=0.30 \pm 0.02$ ) are significantly greater $(p-v a l u e<0.05)$ than glacier meltwater stream riparian vegetation cover $($ mean cover $=64.5 \% \pm 10.9 \%)$ and riparian vegetation density $($ mean NDVI $=$ $0.13 \pm 0.01)$. Point biserial correlation and ordinary least squares modeling showed that both riparian vegetation metrics were positively associated with rock glacier meltwater sourcing. Additionally, riparian vegetation cover was negatively 
associated with mean spring snowfall and maximum winter vapor pressure deficit, while riparian vegetation density was positively associated with mean fall dewpoint. This study shows processes inherent to rock glacier cryospheric meltwater sourcing positively influence first-order meltwater stream vegetation patterns.

\subsection{Introduction}

Previous glacier and rock glacier studies have shown that hydrographs of the meltwater streams they feed are modulated by the type and extent of cryospheric features in the contributing drainage areas (Langston et al. 2011, Pauritsch et al. 2015). Both glacier and rock glacier meltwater hydrographs exhibit diurnal, seasonal and annual variability, though rock glacier runoff variability is relatively muted by comparison to glacier runoff variability (Berger et al. 2004, Gardner and Bajewsky 2013, Geiger et al. 2014). Additionally, glacier specific discharge is significantly higher than rock glacier specific discharge (Krainer and Mostler 2002). Water chemistry and bioavailable nutrient content of glacier and rock glacier meltwater streams also differs significantly. Rock glacier meltwaters exhibit higher $\mathrm{pH}$, conductance, nitrate and most geologically derived cation weathering loads, but lower iron, manganese and ammonium loads, than glacier meltwaters (Fegel et al. 2016). The unique influences of each cryospheric feature type result in divergent in-stream conditions between glacier and rock glacier meltwater streams. Numerous studies have investigated the aquatic ecology of 
glacier meltwater streams (Brown et al. 2003, Brown et al. 2010, Slemmons et al. 2013), though none to our knowledge have directly compared glacier aquatic ecology to rock glacier aquatic ecology. Glacial recession is already threatening sensitive cold-adapted aquatic species habitat, with water temperature increases shown to be a key driver of this habit loss (Muhlfeld et al. 2011). To our knowledge, no previous studies have focused on meltwater stream riparian vegetation patterns for either feature type. Where meltwater stream riparian vegetation has been considered at all, it has generally been within the context of allochthonous nutrient subsidies (Lillehammer and Brittain 1978, Zah and Uelingher 2001), not as a possible response to cryospheric meltwater source type.

Observations made during aerial and satellite image analysis for the Portland State University Contiguous U.S. Rock Glacier Inventory implied systemic differences in riparian vegetation patterns along meltwater streams draining glaciers and rock glaciers. Predictions of widespread transition from glacial to rock glacial forms (Berger 2004, Monnier and Kinnard 2015) necessitate incorporation of rock glacier meltwaters into nascent ecosystem response models developed for glacier meltwaters (Brown et al. 2010). Understanding any systemic riparian vegetation patterns inherent to glacier and rock glacier meltwater streams would be invaluable to these efforts. Shading and evapotranspiration from riparian vegetation adjacent to meltwater streams could plausibly mitigate some of the water temperature increases observed as a result 
of glacier recession. Glacier or rock glacier meltwater streams could conceivably offer refugia and dispersal corridors for sensitive cold adapted species. Results of this riparian vegetation study will have implications for ongoing research of aquatic biology, land cover transition, and cold-adapted species habit and expansion in a warming alpine world.

In this study we employ remote sensing and GIS analysis to evaluate relationships between two cryospheric meltwater source types and their meltwater stream riparian vegetation patterns. We seek to answer three research questions: 1) Is the percent cover of riparian vegetation along rock glacier meltwater streams different than that along glacier meltwater streams?; 2) Is the maximum density of riparian vegetation along rock glacier meltwater streams different than that along glacier meltwater streams?; 3) Can any observed riparian vegetation pattern differences be well explained by meltwater source type?

\subsection{Data and Methods}

\subsubsection{Study Area}

We compared riparian vegetation characteristics along first-order meltwater streams emanating from 35 pairs of collocated glaciers and rock glaciers in California ( $n=3$ pairs), Colorado $(n=1$ pair), Montana $(n=10$ pairs $)$, Washington ( $n=5$ pairs) and Wyoming ( $n=16$ pairs) (Figure 30$)$. Stringent 
selection criteria were applied to ensure that all glaciers and rock glaciers chosen as study sites were directly comparable, as well as generally representative of overall contiguous U.S. glacier and rock glacier populations. Glaciers were selected from a subset of the Randolph Glacier Inventory (RGI) v6.0 (NSIDC, RGI Consortium 2017). Rock glaciers were selected from the Portland State University Contiguous U.S. Rock Glacier Inventory (PDXRGI). Ambiguous features, such as glaciers that flow into large ice-cored terminal moraines or rock glaciers fed by small glacierettes in their accumulation zones, were not considered. Only glaciers and rock glaciers drained primarily by solitary firstorder meltwater stream channels were considered as study area candidates, as excessive channel braiding would confound GIS analysis. All analysis and estimation is completed at $95 \%$ or higher confidence levels.

At each glacier and rock glacier, ArcMap 10.4 Hydrology tools were used in conjunction with the USGS National Elevation Dataset (NED) $1 / 3$ arc-second $(\approx 10$ $\mathrm{m}$ ) digital elevation model to delineate the contributing drainage area and meltwater drainage network. Contributing drainage areas were evaluated to ensure they contained only glacier or rock glacier cryospheric meltwater sources, not a mixture of both. Rock glacier meltwater streams were delineated from the first emergence of a surface channel from the oversteepened terminus. To discount any possible bias introduced by the dramatic geologically recent recession of glaciers, exposing in some cases kilometers of bedrock, glacial meltwater streams were delineated from readily identifiable last glacial maximum 
moraines (Figure 31). This riparian vegetation analysis focuses on the initial 500 $\mathrm{m}$ of first-order meltwater stream channel only, a length constraint necessary to focus on vegetation patterns above local treeline at all meltwater stream pairs. Meltwater streams that pool into tarns or ponds within $500 \mathrm{~m}$ of emergence were likewise omitted from consideration. Automated drainage network delineations were manually corrected to align with five or more independently orthorectified aerial or satellite images to within $2 \mathrm{~m}$. Automated drainage network delineations were quite accurate, with all final manual adjustments less than $5 \mathrm{~m}$, and most less than $1 \mathrm{~m}$. At each glacier and rock glacier the $500 \mathrm{~m}$ long first-order meltwater stream reach was then buffered $15 \mathrm{~m}$ on all sides, providing a total of $17.5 \mathrm{~km}$ of stream channel and $0.55 \mathrm{~km}^{2}$ of riparian zone to be compared for each meltwater stream type. The average distance between each stream pair is $7.18 \mathrm{~km} \pm 2.20 \mathrm{~km}$. The resulting riparian buffer polygons were then used to extract vegetation cover and density metrics, as well as ancillary explanatory information from GIS data sets, for comparisons between glaciers and rock glaciers.

\subsubsection{Data Sources}

Topographic and climatic data were extracted and evaluated for all meltwater stream reaches and contributing drainage areas to ensure both glacier and rock glacier subsets were directly comparable. The USGS NED $1 / 3$ arc-second $(\approx 10$ m) digital elevation model was used to determine topographic characteristics, 
while climatic variables were taken from the Parameter-elevation Relationships on Independent Slopes Model (PRISM) 30 arc-second $(\approx 800 \mathrm{~m})$ resolution raster 1981 - 2010 normals. To the highest level possible, geographic variables known to influence vegetation growth such as elevation, aspect, insolation, precipitation and air temperatures were well controlled for between pairs. Paired statistical comparisons revealed no significant topographic and only a few small climatic differences, implying the study stream reach pairs were well selected to reveal riparian vegetation patterns modulated primarily by meltwater source type (Table 18). Meltwater stream riparian vegetation was investigated using two distinct techniques; the first estimated percent vegetation cover, the second estimated vegetation density. To estimate riparian vegetation cover, the 2011 National Land Cover Database (NLCD) was employed (Homer et al. 2015). To estimate riparian vegetation density, multispectral Landsat 8 Operational Land Imager images were used to calculate Normalized Difference Vegetation Index (NDVI) values.

\subsubsection{Statistical Comparisons}

To understand riparian vegetation percent cover the 2011 NLCD was evaluated twice. First, all original 16 unique NLCD land cover classes were individually extracted for each riparian buffer polygon. Second, the original 16 class NLCD data was simplified by grouping all vegetated $(n=9)$ and all nonvegetated $(n=7)$ classes together, yielding a binary "vegetated/non-vegetated" 
classification. In sparsely and heterogeneously vegetated alpine zones, misclassification within vegetated classes occasionally occurs given the minor spectral disparities between different vegetation classes (Wickham et al. 2017). However, even in areas above treeline, misclassification between vegetated and non-vegetated classes is unlikely given the extreme spectral disparities between vegetated and non-vegetated surfaces. For both NLCD classification schemes, at each stream reach the area representing each unique land cover class was divided by the total reach area, yielding percent cover. Paired t-tests were then used to identify significant differences between glacier and rock glacier meltwater stream riparian vegetation cover.

To estimate riparian vegetation density, Landsat 8 multispectral surface reflectance images collected throughout 2013 - 2018 were retrieved from USGS EarthExplorer (http://earthexplorer.usgs.gov/). Vegetation density was numerically quantified using NDVI, defined as the difference between near infrared and red reflectance divided by the sum of near infrared and red reflectance (Ke et al. 2015). Numerically, NDVI ranges between -1.0, indicating essentially zero vegetation density and biomass, and +1.0 , indicating maximal vegetation density and biomass. Widely applied in landscape ecology, NDVI is one of the most robust remote sensing vegetation indices available (Tian et al. 2015). The Landsat 8 satellite imaging spatial resolution is $30 \mathrm{~m}$ and repeat cycle is 16 days, though considering the regularity of cloud cover in montane environments, as well as smoke from forest fires, acceptable imagery was 
available far less regularly. Only daylight nadir images with less than $10 \%$ cloud cover captured during local stream reach growing seasons were considered. The influence of atmospheric aerosols in images was further reduced using using improved dark-object subtraction (Chavez 1988, Nazeer et al. 2014). Local growing season, defined as the longest contiguous time span with mean air temperatures continually above $0{ }^{\circ} \mathrm{C}$, was estimated from Moderate Resolution Imaging Spectroradiometer (MODIS) satellite derived land surface temperature data. These constraints yield 367 unique 2013-2017 Landsat 8 images for analysis, with each meltwater stream pair clearly imaged between 22 and 100 times. Paired t-tests were then used to identify significant differences between glacier and rock glacier meltwater stream riparian vegetation density.

To understand the magnitude of cryospheric meltwater source type influence on riparian vegetation patterns with respect to local geographic and climatic variable influence, exploratory regression analysis was employed. Using riparian vegetation cover and riparian vegetation density separately as dependent variables, ordinary least squares (OLS) models were built using ancillary geographic and climatic data, as well as cryospheric meltwater source type, as independent variables. A forward stepwise approach was used to build OLS models to determine if cryospheric meltwater source type was a statistically significant predictor of meltwater stream riparian vegetation cover and density. Candidate models were discriminated by adjusted $R^{2}$ values, Akaike Information Criterion Corrected (AICc) scores, significance level of independent variables, 
and count of independent variables in accordance with the principle of parsimony. Mallow's $\mathrm{Cp}$ scores helped verify the best likely variable counts for models without over fitting, and independent variable multicollinearity was constrained using Variance Inflation Factor and Condition Index thresholds of 5 and 30 , respectively

\subsection{Results}

\subsubsection{Riparian Vegetation Cover}

Despite stream pairs occupying virtually identical geographic settings and climatic conditions (Table 18), meltwater streams draining glaciers and rock glaciers exhibited significantly different riparian land cover (Table 19). When considering the original 16 class NLCD land cover data, rock glacier meltwater streams exhibited significantly higher evergreen forest cover (mean cover $=$ $37.1 \% \pm 13.7 \%$ ) than glacier meltwater streams (mean cover $=14.3 \% \pm 8.9 \%$ ) Conversely, rock glacier meltwater streams exhibited significantly lower barren land cover (mean cover $=10.7 \% \pm 7.7 \%$ ) than glacier meltwater streams (mean cover $=31.8 \% \pm 10.1 \%)$. When considering the combined vegetation binary classification NLCD land cover data, rock glacier meltwater streams exhibited significantly higher total riparian vegetation cover (mean cover $=86.2 \% \pm 9.3 \%$ ) than glacier meltwater streams (mean cover $=64.5 \% \pm 10.9 \%$ ). Moran's I and Getis-Ord Gi* spatial analysis of percent vegetation cover differences observed between glacier and rock glacier meltwater streams showed no global clustering, 
hot-spots or coherent regional spatial patterns. Riparian vegetation cover was positively correlated with rock glaciers as the cryospheric meltwater source type (point biserial correlation coefficient $=0.34, p$-value $<0.001$ ), a statistically significant relationship supported by OLS modeling (Table 20).

\subsubsection{Riparian Vegetation Density}

Similarly, meltwater streams draining glaciers and rock glaciers exhibited significantly different riparian vegetation density. When considering all growing seasons together, rock glacier meltwater streams exhibited significantly higher riparian vegetation density (mean NDVI $=0.30 \pm 0.02$ ) than glacier meltwater streams (mean NDVI $=0.13 \pm 0.01$ ) (Figure 32). When considering each growing season individually, rock glacier meltwater stream vegetation densities (NDVI range $=0.24-0.30$ ) were always significantly higher than glacier meltwater stream vegetation densities (NDVI range $=0.10-0.19)($ Figure 32, Table 21). Observed differences in vegetation density between growing seasons showed no temporal trend, and when ranked from smallest to largest are 2016, 2017, 2014, 2013, and 2015 for both cryospheric feature types. When considering each meltwater stream pair individually, rock glacier stream riparian vegetation density was significantly higher than glacier stream riparian vegetation density for 31 of 35 pairs (88.6\%)(Figure 33). Mean rock glacier stream riparian vegetation NDVI values range from -0.01 to 0.67 , while mean glacier stream riparian vegetation NDVI values range from -0.04 to 0.50 (Table 22). Moran's I and Getis-Ord Gi* 
spatial analysis of observed vegetation density differences between glacier and rock glacier meltwater streams showed no global clustering, hot-spots or coherent regional spatial patterns. Riparian vegetation density was positively correlated with rock glaciers as the cryospheric meltwater source type (point biserial correlation coefficient $=0.44, p$-value $<0.001)$, a statistically significant relationship supported by OLS modeling (Table 23).

\subsection{Discussion}

\subsubsection{Riparian Vegetation Cover}

While paired analysis of the original 16 unique NLCD land cover classes revealed only two significant differences between glacier and rock glacier meltwater stream riparian zones (barren land cover and evergreen forest land cover), this may approach may reflect some misclassification error in the original 2011 NLCD data within vegetated classes. Simplifying the data into a binary "vegetated/non-vegetated" classification scheme shows an even more statistically significant difference. An accuracy assessment of the 2011 NLCD showed that misclassification errors occurred most often where pixels were non homogeneous, but that misclassification between vegetated and non-vegetated classes overall was rare (Wickham et al. 2017). Higher confidence for the significant difference observed for the binary "vegetated/non-vegetated" classification scheme, relative to significant differences observed for the original 16 class classification scheme, is therefore based not only on this difference 
having the lowest observed p-value. Additionally, the influence of seasonality with respect to vegetation dynamics in alpine areas is difficult to account for in NLCD data. The 2011 NLCD data is derived from multispectral Landsat Thematic Mapper imagery collected and averaged throughout the entire year, meaning the interplay between seasonal snow cover and seasonal vegetation is poorly resolved. A final consideration is the fact that mountainous areas, particularly valley bottoms where our study sites are situated, are often obscured by clouds and deep shadows, further limiting the annual average processing used to create the 2011 NLCD.

\subsubsection{Riparian Vegetation Density}

When considering glacier and rock glacier meltwater stream riparian vegetation density for each of the five growing seasons evaluated, the smallest (though still statistically significant) difference was observed for 2016, when both meltwater stream types showed the lowest NDVI values observed. Several substantial contiguous U.S. climate anomalies could plausibly account for some of this pattern, including above average winter and spring air temperatures, as well as above average snowfall and precipitation generally (NOAA 2017). The use of MODIS $1000 \mathrm{~m}$ resolution satellite derived land surface temperature data to define growing seasons is also a limitation of this study. A more nuanced, though technically challenging, solution for future reanalysis could involve using Landsat $30 \mathrm{~m}$ resolution multispectral data to attempt to derive land surface 
temperature. However, present difficulties of such a technique place such an approach well beyond the scope of this study. The USGS is actively developing provisional Landsat Surface Temperature Product algorithms, but as of April 2018 the official product maturity (on a scale of 1-6, where 1 = "little or no utility" and 6 $=$ "operationally efficient") is 1 , with a rating of 6 not expected until 2020 at least.

When considering glacier and rock glacier meltwater stream riparian vegetation density for each stream pair individually, only four stream pairs did not exhibit statistically higher NDVI values for the rock glacier stream. However, these four stream pairs also had the four lowest rock glacier riparian NDVI values observed. At three of these stream pairs (22(WY), 26(WY), 29(WY)), all in the Wind River Range of Wyoming, rock glacier riparian NDVI values were significantly lower than glacier riparian NDVI values in all five growing seasons considered. At all three of these pairs the glacier meltwater streams received more summer insolation than the rock glacier streams. Additionally, at pairs 22(WY) and 26(WY) the mean glacier meltwater stream elevation was nearly 200 $\mathrm{m}$ lower than the mean rock glacier meltwater stream elevation, and at pair 29 (WY) the mean glacier meltwater stream slope was 21 degrees shallower than the rock glacier meltwater stream slope. The final stream pair (1(CA)), in the Sierra Nevada of California, did exhibit slightly higher NDVI values for the rock glacier stream when considering all growing seasons together, but the difference was not statistically significant. Additionally, the average rock glacier NDVI at this pair was significantly higher than the average glacier NDVI in 2014, 2016 and 
2017, but not in 2013 or 2015 . All meltwater stream pairs could be better described with a more accurate growing season estimate such as what will ultimately be possible upon completion of the aforementioned USGS Landsat Surface Temperature Product. This is especially true for the three stream pairs in Wyoming just described, which sit in steeply incised east-west valleys surrounded by relatively high, flat plateaus and as such are likely below $0{ }^{\circ} \mathrm{C}$ for much more of the year than MODIS $1000 \mathrm{~m}$ resolution satellite derived land surface temperature data imply.

Riparian vegetation cover and density findings strongly suggest processes inherent to glaciers and rock glaciers as meltwater sources manifest at the landscape scale, with riparian vegetation favoring rock glacier meltwater streams. Though the exact mechanisms of these forcings is uncertain, the high hydrograph variability of glacial meltwater streams relative to rock glacier meltwater streams observed in previous studies (Bajewsky and Gardner 1989, Geiger et al. 2014, Wagner et al. 2016) could plausibly be a factor. These systemic hydrograph variability differences could lead to increased channel depths, decreased bank stability, and decreased near-stream soil water availability along glacier meltwater streams, a hypothesis supported by previous research in non-meltwater streams (Simon et al. 2006, Bertoldi et al 2010).

When discussing montane climate change, a common theme is upslope migration of cold adapted species (Hillyer and Silman 2010, Bell et al. 2014). 
During past climatic warming periods, mountains have offered critical refugia for cold-adapted species (Sandel et al. 2011), but montane topography is complex and the relationship between decreasing area with increasing elevation is neither linear nor uniform for every mountain range. While total mountain surface area always decreases with elevation, previous research has shown that some mountain ranges, having steeper slopes than others, lose area with increasing elevation far more rapidly (Elsen and Tingly 2015). Given the high rates of montane warming seen recently and widely predicted to accelerate in the near future, the hypothesis that cold adapted plant species will simply shift the elevation of their ranges by dispersing upslope in response to climate change has not been tested adequately (Monahan et al. 2013, Morueta-Holme et al. 2015). Studies of cold adapted insects and small mammals also show them struggling to adapt to montane warming by upslope range expansion (Beever et al. 2011, Bassler et al. 2013).

Riparian corridors have been shown to be critical pathways for genetic information flow across landscapes at lower elevations (Sabo et al. 2005, Bennett et al. 2014, Fremier et al. 2015), and we expect the same is also true at higher elevations. Initial studies show habitat contiguity to be a primary control on upslope species migration (Feeley et al. 2011, Forero-Medina et al. 2011). The desiccation of standing water bodies such as lakes and tarns in response to snowfield and glacier recession driven by montane warming (Bush et al. 2010) could mean the relatively stable hydrographs of rock glacier meltwater streams 
compared to glaciers (Millar et al. 2013b) will play an important role in upslope range expansion of cold adapted species. The high hydrograph variability of glacier meltwater stream networks (Fountain 1985) often leads to deeply incised stream channels, which have been shown to have lower mammalian habitat use activity (Brown et al. 2008). Functional connectivity between terrestrial and aquatic habitats, such as that resulting from higher riparian vegetation coverages and densities, has been shown to greatly boost species dispersal (Beger et al. 2010). We posit alpine streams with stable riparian vegetation, such as rock glacier meltwater streams, could become critical pathways for warming-driven upslope species range shifts given the importance of allochthonous nutrient and biomass supply to montane stream network productivity (Zah and Uelinger 2001)

\subsection{Conclusions}

Riparian vegetation along first-order rock glacier meltwater streams covers significantly more area and is significantly denser than riparian vegetation along first-order glacier meltwater streams. When considering plausible forcings for these observed differences, cryospheric meltwater feature type is a statistically significant predictor, and the only spatially distinct predictor identified in this study. Climatically related predictors identified in meltwater stream riparian vegetation analysis can be interpreted as either influencing the length of the effective growing season or severity of the non-growing season. Increasing mean spring snowfall, negatively associated with meltwater stream riparian vegetation 
cover, could easily delay the start of the growing season, especially along stream channels where wind deposition can increase snow depth and cold air drainage can delay snowmelt. Increasing maximum winter vapor pressure deficit, also negatively associated with meltwater stream riparian vegetation cover, could easily result in more severe frost damage to riparian vegetation between growing seasons. Increasing mean fall dewpoint, positively associated with meltwater stream riparian vegetation density, could easily extend the length of the effective growing season by preventing riparian vegetation from succumbing to parched, dry soil conditions late in the season.

This study evaluated collocated stream pairs in a defensible attempt to control for geographic and climatic variables known to influence alpine vegetation patterns, but this spatially constrained approach does result in a small sample size of 70 meltwater streams. With over 800 known glaciers and over 10,000 known rock glaciers across the contiguous U.S., one avenue for expansion of this research would be to increase the number of stream reaches available for study by adopting an unpaired statistical analytical framework. Another avenue for future research would be field-based evaluation of geographic and climatic variables along meltwater stream reaches. At present, available ancillary topographic GIS data lacks the spatial resolution to determine meltwater stream channel depths and cross sections. Similarly, soil moisture and hydraulic conductivity data for these riparian zones is unavailable from remote sensing data. 


\section{Chapter 5: Discussion}

Past rock glacier inventory efforts in other regions have been limited in spatial scope, and have rarely been used by the research groups initially creating them for analysis beyond compilation and simple comparison of rudimentary descriptive statistics. In the course of this dissertation research I have developed a powerful data set for future alpine cryospheric studies, the Portland State University Rock Glacier Inventory (PDXRGI), and applied it to three unique avenues of investigation. When considering previous rock glacier inventory efforts globally, the PDXRGI is unprecedented in both spatial extent and count of rock glaciers identified. This resource, to be hosted online and made publicly available, will doubtless be subject to future revisions and refinement, but even in its present "version 1.0" state is eagerly awaited by dozens of research groups.

Throughout this research, I have developed geospatially explicit models for fundamental rock glacier patterns built on robust predictors that highlight the unique roles of geographic, climatic and land cover influences. In Chapter 1, the importance of mean spring dewpoint temperature and percent barren land cover in understanding rock glacier spatial distribution patterns is identified and quantified. In Chapter 2, I omit the influence of land cover from consideration and compare the spatial distributions of rock glaciers to glaciers, identifying the importance of mean spring dewpoint temperature and slope standard deviation in understanding rock glacier distributions, and the importance of elevation range 
and mean fall snowfall in understanding glacier distributions. In Chapter 3, I consider the influences glaciers and rock glaciers may have on the landscapes around them, identifying and quantifying significant differences in meltwater stream riparian vegetation cover and density metrics, both of which are positively associated with rock glacier meltwater sourcing.

In summary, this research contributes to the nascent yet rapidly expanding scientific understanding of the alpine cryosphere generally and rock glaciers specifically, and I am excited to see what future insights might be revealed by additional study and wider application of the PDXRGI. European researchers were the first to identify and formally study rock glaciers, all work that has greatly informed my own investigations, but have yet to integrate the numerous small rock glacier inventories completed there into a single coherent data set. South American researchers have done much work to address rock glaciers of the Southern Andes, especially in Chile and Argentina, but have yet to expand their gaze farther north on the continent. My hope is that all regional rock glacier inventory efforts to date will begin to be collated, standardized, made publicly available, and then applied to under-studied regions, particularly in Asia. With perseverance, collaboration, and no small amount of luck, the rock glacier research community may soon have a truly global inventory at their disposal, something the glacier research community has enjoyed for decades. 


\section{Tables}

\section{Chapter 2 Tables}

Table 1: Notable previous rock glacier inventories identified during comprehensive literature review. Only inventories that identified $>50$ rock glaciers (i.e. at least regional scale) are included here, though sporadic smaller local inventories have been compiled. The geospatial rock glacier inventory compiled for this dissertation research dwarfs previous inventories in both study area and number of rock glaciers identified, and is eagerly awaited by the alpine cryosphere, ecology and geomorphology research communities.

\begin{tabular}{|l|l|r|}
\hline \multicolumn{1}{|c|}{ Continent } & \multicolumn{1}{|c|}{ Primary Investigator(s) } & Rock Glaciers Identified \\
\hline Esia & Bolch and Gorbunov (2014) & 72 \\
\hline \multirow{5}{*}{ Europe } & Cremonese and others (2011) & 4795 \\
\cline { 2 - 3 } & Baroni et al. (2004) & 216 \\
\cline { 2 - 3 } & Delaloye et al. (1998) & 321 \\
\cline { 2 - 3 } & Frauenfelder et al. (2005) & 84 \\
\cline { 2 - 3 } & Imhof (1996) & 80 \\
\cline { 2 - 3 } & Keller-Pirklbauer et al. (2012) & 1647 \\
\cline { 2 - 3 } & Kenner and Magnusson (2017) & 239 \\
\cline { 2 - 3 } & Krainer and Ribis (2012) & 3145 \\
\cline { 2 - 3 } & Lambiel and Reynard (2001) & 239 \\
\cline { 2 - 3 } & Scotti et al. (2013) & 1514 \\
\cline { 2 - 3 } & Seppi at al. (2012) & 705 \\
\hline \multirow{5}{*}{ North America } & Millar and Westfall (2008) & 289 \\
\cline { 2 - 3 } & Humlum (2000) & 400 \\
\cline { 2 - 3 } & Janke (2007) & 220 \\
\cline { 2 - 3 } & Janke and Frauenfelder (2008) & 180 \\
\hline & Liu et al. (2013) & 67 \\
\hline \multirow{5}{*}{ South America } & Angillieri (2010) & 155 \\
\hline & Falashi et al. (2014) & 488 \\
\cline { 2 - 3 } & Falaschi et al. (2015) & 177 \\
\cline { 2 - 3 } & Rangecroft et al. (2014) & 94 \\
\hline
\end{tabular}


Table 2: Ancillary GIS data used as explanatory variables in Chapter 2.

\begin{tabular}{|l|l|l|}
\hline GIS Data & Spatial Resolution & Source \\
\hline $\begin{array}{l}\text { elevation, slope, aspect, } \\
\text { insolation }\end{array}$ & $10 \mathrm{~m}$ raster & $\begin{array}{l}\text { National Elevation Dataset, } \\
\text { USGS 2017 }\end{array}$ \\
\hline land cover & $30 \mathrm{~m}$ raster & $\begin{array}{l}\text { NLCD 1992-2011, Homer et al. } \\
2015\end{array}$ \\
\hline $\begin{array}{l}\text { temperature, precipitation, } \\
\text { vapor pressure }\end{array}$ & $800 \mathrm{~m}$ raster & $\begin{array}{l}\text { PRISM 1981 - 2010 normals, } \\
\text { PRISM 2015 }\end{array}$ \\
\hline
\end{tabular}


Table 3: Summary topographic and atmospheric statistics for Chapter 2 HUC12 rock glacier model calibration and validation domains.

\begin{tabular}{|c|c|c|c|c|c|c|c|c|}
\hline \multirow[t]{2}{*}{ Variable } & \multicolumn{4}{|c|}{ Calibration Watersheds $(n=1144)$} & \multicolumn{4}{|c|}{ Validation Watersheds $(n=379)$} \\
\hline & Min & Mean & Max & SD & Min & Mean & Max & SD \\
\hline $\begin{array}{l}\text { Rock Glacier } \\
\text { Area }(\%)\end{array}$ & $<0.01$ & 0.78 & 7.30 & 1.11 & $<0.01$ & 0.69 & 7.63 & 0.95 \\
\hline $\begin{array}{l}\text { HUC12 Area } \\
\left(\mathrm{km}^{2}\right)\end{array}$ & 19.20 & 93.65 & 794.91 & 44.74 & 32.13 & 89.18 & 220.28 & 34.03 \\
\hline Elevation (m) & 987 & 2537 & 3700 & 569 & 1085 & 2521 & 3638 & 568 \\
\hline Slope $\left(^{\circ}\right)$ & 3.94 & 19.32 & 34.54 & 5.98 & 5.18 & 19.51 & 32.24 & 5.67 \\
\hline Eastness & -0.05 & $<0.01$ & 0.05 & 0.01 & -0.03 & $<0.01$ & 0.05 & 0.01 \\
\hline Northness & -0.04 & $<0.01$ & 0.36 & 0.02 & -0.04 & $<0.01$ & 0.17 & 0.02 \\
\hline $\begin{array}{l}\text { Annual Solar } \\
\text { Insolation } \\
\left(\mathrm{Wh} \cdot \mathrm{m}^{-2}\right)\end{array}$ & 78,978 & 118,944 & 151,601 & 16,032 & 78,710 & 118,164 & 150,963 & 16,012 \\
\hline $\begin{array}{l}\text { Annual } \\
\text { Temperature } \\
\left({ }^{\circ} \mathrm{C}\right)\end{array}$ & -1.58 & 2.84 & 13.52 & 2.12 & -1.09 & 2.90 & 11.05 & 2.08 \\
\hline $\begin{array}{l}\text { Annual } \\
\text { Freezing Area } \\
(\%)\end{array}$ & $<0.01$ & 41.93 & 58.76 & 8.36 & 0.55 & 41.74 & 57.14 & 8.41 \\
\hline $\begin{array}{l}\text { Annual } \\
\text { Dewpoint }\left({ }^{\circ} \mathrm{C}\right)\end{array}$ & -10.59 & -6.00 & 2.93 & 2.09 & -10.15 & -5.88 & 2.22 & 2.13 \\
\hline $\begin{array}{l}\text { Annual Vapor } \\
\text { Pressure } \\
\text { Deficit (hPa) }\end{array}$ & 3.05 & 5.74 & 13.99 & 1.30 & 2.90 & 5.73 & 12.49 & 1.27 \\
\hline $\begin{array}{l}\text { Annual } \\
\text { Precipitation } \\
(\mathrm{cm})\end{array}$ & 17.02 & 70.84 & 299.50 & 27.47 & 22.27 & 72.12 & 201.30 & 28.76 \\
\hline $\begin{array}{l}\text { Annual } \\
\text { Precipitation } \\
\text { As Snow (\%) }\end{array}$ & $<0.01$ & 50.85 & 86.58 & 13.07 & 0.75 & 50.48 & 84.25 & 11.97 \\
\hline
\end{tabular}


Table 4: Summary 2011 NLCD land cover statistics for Chapter 2 HUC12 rock glacier model calibration and validation domains.

\begin{tabular}{|l|r|r|r|r|r|r|r|r|}
\hline \multirow{2}{*}{ Variable } & \multicolumn{3}{|c|}{ Calibration Watersheds $(\mathrm{n}=1144)$} & \multicolumn{3}{c|}{ Validation Watersheds $(\mathrm{n}=379)$} \\
\cline { 2 - 10 } & \multicolumn{1}{c|}{ Min } & \multicolumn{1}{c|}{ Mean } & \multicolumn{1}{c|}{ Max } & \multicolumn{1}{c|}{ SD } & Min & Mean & \multicolumn{1}{c|}{ Max } & SD \\
\hline Water (\%) & $<0.01$ & 0.60 & 40.66 & 2.05 & $<0.01$ & 0.52 & 18.76 & 1.64 \\
\hline Developed (\%) & $<0.01$ & 0.64 & 65.77 & 2.28 & $<0.01$ & 0.69 & 16.44 & 1.75 \\
\hline Barren (\%) & $<0.01$ & 7.07 & 68.46 & 10.19 & $<0.01$ & 6.48 & 64.22 & 9.52 \\
\hline Forest (\%) & 0.58 & 51.76 & 95.04 & 21.13 & 1.32 & 52.75 & 94.56 & 20.76 \\
\hline Shrub (\%) & 2.04 & 36.76 & 96.34 & 19.41 & 1.65 & 36.39 & 89.34 & 19.19 \\
\hline Agriculture (\%) & $<0.01$ & 1.17 & 45.27 & 3.49 & $<0.01$ & 1.25 & 60.88 & 4.46 \\
\hline Wetland (\%) & $<0.01$ & 1.36 & 32.96 & 2.27 & $<0.01$ & 1.31 & 17.82 & 2.10 \\
\hline Snow/lce (\%) & $<0.01$ & 0.65 & 25.10 & 2.48 & $<0.01$ & 0.60 & 15.87 & 2.07 \\
\hline
\end{tabular}


Table 5: Rock glacier counts by class and NOAA region.

\begin{tabular}{|l|r|r|r|r|}
\hline \multicolumn{1}{|c|}{ NOAA Region } & \multicolumn{1}{c|}{ Class 1 } & \multicolumn{1}{c|}{ Class 2 } & \multicolumn{1}{c|}{ Class 3 } & \multicolumn{1}{c|}{ Total } \\
\hline NW region & $1295(65 \%)$ & $513(26 \%)$ & $189(9 \%)$ & 1997 \\
\hline SW region & $3291(68 \%)$ & $1133(23 \%)$ & $446(9 \%)$ & 4870 \\
\hline W region & $552(68 \%)$ & $181(22 \%)$ & $84(10 \%)$ & 817 \\
\hline WNC region & $1914(72 \%)$ & $589(22 \%)$ & $156(6 \%)$ & 2659 \\
\hline All regions & $7052(68 \%)$ & $2416(23 \%)$ & $875(8 \%)$ & 10,343 \\
\hline
\end{tabular}


Table 6: Chapter 2 rock glacier OLS and GWR calibration model comparisons overview.

\begin{tabular}{|l|c|c|c|}
\hline \multicolumn{4}{|c|}{ HUC12 Rock Glacier Percent Area Calibration Models Comparison ( $\mathrm{n}=1144$ ) } \\
\hline Variable & OLS Model & GWR Model (full) & GWR Model (final) \\
\hline Adjusted R ${ }^{2}$ & 0.26 & 0.36 & 0.43 \\
\hline AICc & -7392 & -7533 & -7644 \\
\hline Intercept & -0.16 & -0.030 to 0.0017 & -0.033 to 0.036 \\
\hline $\begin{array}{l}\text { Mean Spring Dewpoint } \\
\text { Temperature }\end{array}$ & -0.0011 & -0.0028 to 0.00033 & -0.0061 to 0.0037 \\
\hline $\begin{array}{l}\text { Percent Barren Land } \\
\text { Cover }\end{array}$ & 0.028 & 0.0034 to 0.090 & -0.018 to 0.46 \\
\hline $\begin{array}{l}\text { Slope Standard } \\
\text { Deviation }\end{array}$ & 0.00093 & -0.00016 to 0.0022 & NA \\
\hline $\begin{array}{l}\text { Mean Winter } \\
\text { Temperature }\end{array}$ & -0.00067 & -0.0014 to 0.00057 & NA \\
\hline
\end{tabular}


Table 7: Chapter 2 rock glacier OLS and GWR validation model comparisons overview.

\begin{tabular}{|l|c|c|c|}
\hline \multicolumn{4}{|c|}{ HUC12 Rock Glacier Percent Area Validation Models Comparison ( $\mathrm{n}=379$ ) } \\
\hline Variable & OLS Model & GWR Model (full) & GWR Model (final) \\
\hline Adjusted R ${ }^{2}$ & 0.20 & 0.27 & 0.50 \\
\hline AICc & -2530 & -2564 & -2658 \\
\hline Intercept & -0.0096 & -0.016 to 0.00098 & -0.049 to 0.062 \\
\hline $\begin{array}{l}\text { Mean Spring Dewpoint } \\
\text { Temperature }\end{array}$ & -0.00067 & -0.0017 to 0.00041 & -0.0073 to 0.0067 \\
\hline $\begin{array}{l}\text { Percent Barren Land } \\
\text { Cover }\end{array}$ & 0.023 & 0.013 to 0.0070 & -0.0055 to 0.32 \\
\hline $\begin{array}{l}\text { Slope Standard } \\
\text { Deviation }\end{array}$ & 0.00055 & 0.00026 to 0.0010 & NA \\
\hline $\begin{array}{l}\text { Mean Winter } \\
\text { Temperature }\end{array}$ & -0.00073 & -0.00092 to -0.000020 & NA \\
\hline
\end{tabular}


Table 8: Chapter 2 rock glacier OLS and GWR global model comparisons overview.

\begin{tabular}{|l|c|c|c|}
\hline \multicolumn{4}{|c|}{ HUC12 Rock Glacier Percent Area Global Models Comparison ( $\mathrm{n}=1523$ ) } \\
\hline Variable & OLS Model & GWR Model (full) & GWR Model (final) \\
\hline Adjusted R ${ }^{2}$ & 0.25 & 0.34 & 0.45 \\
\hline AICc & -9919 & $-10,114$ & $-10,341$ \\
\hline Intercept & -0.014 & -0.026 to 0.0034 & -0.038 to 0.042 \\
\hline $\begin{array}{l}\text { Mean Spring Dewpoint } \\
\text { Temperature }\end{array}$ & -0.00097 & -0.0025 to 0.00013 & -0.0061 to 0.0044 \\
\hline $\begin{array}{l}\text { Percent Barren Land } \\
\text { Cover }\end{array}$ & 0.027 & 0.0044 to 0.089 & -0.011 to 0.46 \\
\hline $\begin{array}{l}\text { Slope Standard } \\
\text { Deviation }\end{array}$ & -0.00084 & -0.00016 to 0.0022 & NA \\
\hline $\begin{array}{l}\text { Mean Winter } \\
\text { Temperature }\end{array}$ & -0.00067 & -0.0012 to 0.00051 & NA \\
\hline
\end{tabular}


Table 9: Global Moran's Index clustering statistics for Chapter 2 rock glacier OLS and GWR models standardized residuals. All metrics calculated using inverse distance squared weighting and row standardization.

\begin{tabular}{|c|c|c|c|}
\hline \multicolumn{4}{|c|}{ HUC12 Rock Glacier Percent Area Calibration Models Comparison $(n=1144)$} \\
\hline Variable & OLS Model & GWR Model (full) & GWR Model (final) \\
\hline Moran's Index & 0.23 & 0.20 & 0.13 \\
\hline z-score & 16.84 & 14.20 & 9.12 \\
\hline Pattern & Clustered & Clustered & Clustered \\
\hline \multicolumn{4}{|c|}{ HUC12 Rock Glacier Percent Area Validation Models Comparison $(n=379)$} \\
\hline Variable & OLS Model & GWR Model (full) & GWR Model (final) \\
\hline Moran's Index & 0.16 & 0.15 & 0.035 \\
\hline z-score & 6.42 & 6.14 & 1.47 \\
\hline Pattern & Clustered & Clustered & Clustered \\
\hline \multicolumn{4}{|c|}{ HUC12 Rock Glacier Percent Area Global Models Comparison $(n=1523)$} \\
\hline Variable & OLS Model & GWR Model (full) & GWR Model (final) \\
\hline Moran's Index & 0.24 & 0.21 & 0.13 \\
\hline z-score & 21.87 & 18.76 & 11.44 \\
\hline Pattern & Clustered & Clustered & Clustered \\
\hline
\end{tabular}


Table 10: Locally significant Chapter 2 rock glacier final GWR global model variable sign change statistics.

\begin{tabular}{|l|r|r|}
\hline \multirow{2}{*}{ Model Value } & \multicolumn{2}{|c|}{ Mean Spring Dewpoint Temperature } \\
\cline { 2 - 3 } & \multicolumn{2}{|c|}{$\begin{array}{c}\text { Negative Coefficient } \\
(\mathrm{n}=389)\end{array}$} \\
\hline Local $\mathrm{R}^{2}$ & 0.33 & 0.41 \\
\hline Standardized Residual & -0.0044 & 0.27 \\
\hline Condition Index & 15.73 & 19.82 \\
\hline Intercept & -0.011 & -0.015 \\
\hline Coefficient & -0.019 & 0.0014 \\
\hline $\begin{array}{l}\text { Mean Spring Dewpoint } \\
\text { Temperature Input Data }\end{array}$ & -6.81 & -9.26 \\
\hline
\end{tabular}




\section{Chapter 3 Tables}

Table 11: Ancillary GIS data used as explanatory variables in Chapter 3.

\begin{tabular}{|l|l|l|}
\hline GIS Data & Spatial Resolution & Source \\
\hline $\begin{array}{l}\text { elevation, slope, aspect, } \\
\text { insolation }\end{array}$ & $10 \mathrm{~m}$ raster & $\begin{array}{l}\text { National Elevation Dataset, } \\
\text { USGS 2017 }\end{array}$ \\
\hline $\begin{array}{l}\text { temperature, precipitation, } \\
\text { vapor pressure }\end{array}$ & $800 \mathrm{~m}$ raster & $\begin{array}{l}\text { PRISM } 1981 \text { - } 2010 \text { normals, } \\
\text { PRISM 2015 }\end{array}$ \\
\hline
\end{tabular}


Table 12: Summary statistics for Chapter 3 HUC12 glacier model calibration and validation domains.

\begin{tabular}{|c|c|c|c|c|c|c|c|c|}
\hline \multirow[t]{2}{*}{ Variable } & \multicolumn{4}{|c|}{$\begin{array}{l}\text { Calibration Watersheds } \\
\qquad(n=194)\end{array}$} & \multicolumn{4}{|c|}{$\begin{array}{l}\text { Validation Watersheds } \\
\qquad(n=63)\end{array}$} \\
\hline & Min & Mean & Max & SD & Min & Mean & Max & SD \\
\hline Glacier Area (\%) & $<0.01$ & 2.08 & 21.00 & 3.39 & $<0.01$ & 1.96 & 12.93 & 2.82 \\
\hline HUC12 Area $\left(\mathrm{km}^{2}\right)$ & 38.91 & 97.33 & 220.28 & 33.03 & 34.78 & 98.74 & 195.91 & 34.88 \\
\hline Elevation (m) & 702.18 & 1934.08 & 3517.10 & 796.56 & 633.78 & 1915.08 & 3453.24 & 746.25 \\
\hline Slope $\left({ }^{\circ}\right)$ & 8.25 & 24.68 & 34.74 & 5.97 & 9.22 & 23.26 & 36.38 & 6.20 \\
\hline Eastness & -0.02 & $<0.01$ & 0.03 & $<0.01$ & -0.03 & $<0.01$ & 3.07 & 1.03 \\
\hline Northness & -0.02 & $<0.01$ & $<0.01$ & 0.02 & -0.03 & $<0.01$ & 14.30 & 0.02 \\
\hline $\begin{array}{l}\text { Annual Solar Radiation } \\
\left(\mathrm{Wh} \cdot \mathrm{m}^{-2}\right)\end{array}$ & 73,925 & 100,294 & 146,529 & 19,544 & 72,923 & 101,394 & 140,130 & 18,480 \\
\hline $\begin{array}{l}\text { Annual Temperature } \\
\left({ }^{\circ} \mathrm{C}\right)\end{array}$ & -1.58 & 3.62 & 9.40 & 2.30 & -1.47 & 3.78 & 8.55 & 2.30 \\
\hline $\begin{array}{l}\text { Annual Freezing Area } \\
(\%)\end{array}$ & 0.48 & 34.75 & 58.76 & 14.05 & 1.49 & 34.27 & 58.02 & 13.98 \\
\hline Annual Dewpoint $\left({ }^{\circ} \mathrm{C}\right)$ & -10.15 & -3.31 & 4.30 & 3.66 & -10.00 & -3.25 & 4.29 & 3.51 \\
\hline $\begin{array}{l}\text { Annual Vapor Pressure } \\
\text { Deficit }(\mathrm{hPa})\end{array}$ & 2.90 & 4.72 & 8.08 & 0.93 & 3.07 & 4.89 & 8.83 & 1.17 \\
\hline $\begin{array}{l}\text { Annual Precipitation } \\
(\mathrm{cm})\end{array}$ & 50.03 & 152.09 & 372.08 & 72.62 & 34.15 & 146.94 & 362.79 & 72.00 \\
\hline $\begin{array}{l}\text { Annual Precipitation As } \\
\text { Snow }(\%)\end{array}$ & 1.20 & 52.13 & 84.69 & 18.74 & 2.80 & 52.10 & 83.96 & 18.60 \\
\hline
\end{tabular}


Table 13: Summary statistics for Chapter 3 HUC12 rock glacier model calibration and validation domains.

\begin{tabular}{|c|c|c|c|c|c|c|c|c|}
\hline \multirow[t]{2}{*}{ Variable } & \multicolumn{4}{|c|}{$\begin{array}{l}\text { Calibration Watersheds } \\
\qquad(\mathrm{n}=1144)\end{array}$} & \multicolumn{4}{|c|}{$\begin{array}{l}\text { Validation Watersheds } \\
\qquad(\mathrm{n}=379)\end{array}$} \\
\hline & Min & Mean & Max & SD & Min & Mean & Max & SD \\
\hline Rock Glacier Area (\%) & $<0.01$ & 0.78 & 7.30 & 1.11 & $<0.01$ & 0.69 & 7.63 & 0.95 \\
\hline HUC12 Area $\left(\mathrm{km}^{2}\right)$ & 19.20 & 93.65 & 794.91 & 44.74 & 32.13 & 89.18 & 220.28 & 34.03 \\
\hline Elevation (m) & 987.39 & 2537.24 & 3700.15 & 568.53 & 1085.10 & 2521.93 & 3637.68 & 568.47 \\
\hline Slope $\left({ }^{\circ}\right)$ & 3.94 & 19.32 & 34.54 & 5.98 & 5.18 & 19.51 & 32.24 & 5.67 \\
\hline Eastness & -0.05 & $<0.01$ & 0.05 & 0.01 & -0.03 & $<0.01$ & 0.05 & 0.01 \\
\hline Northness & -0.04 & $<0.01$ & 0.36 & 0.02 & -0.04 & $<0.01$ & 0.17 & 0.02 \\
\hline $\begin{array}{l}\text { Annual Solar } \\
\text { Radiation }\left(\mathrm{Wh} \cdot \mathrm{m}^{-2}\right)\end{array}$ & 78,978 & 118,944 & 151,601 & 16,032 & 78,710 & 118,164 & 150,963 & 16,012 \\
\hline $\begin{array}{l}\text { Annual Temperature } \\
\left({ }^{\circ} \mathrm{C}\right)\end{array}$ & -1.58 & 2.84 & 13.52 & 2.12 & -1.09 & 2.90 & 11.05 & 2.08 \\
\hline $\begin{array}{l}\text { Annual Freezing Area } \\
(\%)\end{array}$ & $<0.01$ & 41.93 & 58.76 & 8.36 & 0.55 & 41.74 & 57.14 & 8.41 \\
\hline Annual Dewpoint $\left({ }^{\circ} \mathrm{C}\right)$ & -10.59 & -6.00 & 2.93 & 2.09 & -10.15 & -5.88 & 2.22 & 2.13 \\
\hline $\begin{array}{l}\text { Annual Vapor } \\
\text { Pressure Deficit }(\mathrm{hPa})\end{array}$ & 3.05 & 5.74 & 13.99 & 1.30 & 2.90 & 5.73 & 12.49 & 1.27 \\
\hline $\begin{array}{l}\text { Annual Precipitation } \\
(\mathrm{cm})\end{array}$ & 17.02 & 70.84 & 299.50 & 27.47 & 22.27 & 72.12 & 201.30 & 28.76 \\
\hline $\begin{array}{l}\text { Annual Precipitation } \\
\text { As Snow (\%) }\end{array}$ & $<0.01$ & 50.85 & 86.58 & 13.07 & 0.75 & 50.48 & 84.25 & 11.97 \\
\hline
\end{tabular}


Table 14: Chapter 3 glacier OLS and GWR calibration, validation and global model comparisons overview.

\begin{tabular}{|c|c|c|c|}
\hline \multicolumn{4}{|c|}{ HUC12 Glacier Percent Area Calibration Models Comparison $(n=194)$} \\
\hline Variable & OLS Model & GWR Model (full) & GWR Model (final) \\
\hline Adjusted $\mathrm{R}^{2}$ & 0.45 & 0.50 & 0.54 \\
\hline AICc & -873 & -884 & -885 \\
\hline Intercept & -0.022 & -0.40 to 0.069 & -0.18 to 0.027 \\
\hline Elevation Range & 0.000035 & $\begin{array}{l}0.0000060 \text { to } \\
0.000045\end{array}$ & -0.0000040 to 0.000067 \\
\hline Mean Fall Snowfall & 0.00034 & 0.000010 to 0.00040 & -0.000018 to 0.00122 \\
\hline $\begin{array}{l}\text { Max Summer Vapor } \\
\text { Pressure Deficit }\end{array}$ & -0.0030 & -0.0048 to -0.00053 & NA \\
\hline \multicolumn{4}{|c|}{ HUC12 Glacier Percent Area Validation Models Comparison $(n=63)$} \\
\hline Variable & OLS Model & GWR Model (full) & GWR Model (final) \\
\hline Adjusted $\mathrm{R}^{2}$ & 0.58 & 0.56 & 0.55 \\
\hline $\mathrm{AICc}$ & -318 & -313 & -312 \\
\hline Intercept & -0.028 & -0.033 to 0.0089 & 0.00018 to 0.069 \\
\hline Elevation Range & 0.000025 & $\begin{array}{c}0.000016 \text { to } \\
0.000028\end{array}$ & -0.0000080 to 0.000071 \\
\hline Mean Fall Snowfall & 0.00043 & 0.00038 to 0.00049 & -0.00013 to 0.00091 \\
\hline $\begin{array}{l}\text { Max Summer Vapor } \\
\text { Pressure Deficit }\end{array}$ & -0.0018 & -0.0037 to -0.0010 & NA \\
\hline \multicolumn{4}{|c|}{ HUC12 Glacier Percent Area Global Models Comparison $(n=257)$} \\
\hline Variable & OLS Model & GWR Model (full) & GWR Model (final) \\
\hline Adjusted $\mathrm{R}^{2}$ & 0.47 & 0.51 & 0.55 \\
\hline $\mathrm{AICc}$ & -1188 & -1203 & -1201 \\
\hline Intercept & -0.022 & -0.038 to 0.052 & 0.18 to 0.016 \\
\hline Elevation Range & 0.000032 & $\begin{array}{l}0.0000090 \text { to } \\
0.000040\end{array}$ & -0.0000040 to 0.000067 \\
\hline Mean Fall Snowfall & 0.00036 & 0.00012 to 0.00041 & -0.000018 to 0.0012 \\
\hline $\begin{array}{l}\text { Max Summer Vapor } \\
\text { Pressure Deficit }\end{array}$ & -0.0027 & -0.0050 to -0.00078 & NA \\
\hline
\end{tabular}


Table 15: Global Moran's Index clustering statistics for Chapter 3 OLS and GWR glacier models standardized residuals. All metrics calculated using inverse distance squared weighting and row standardization.

\begin{tabular}{|c|c|c|c|}
\hline \multicolumn{4}{|c|}{ HUC12 Glacier Percent Area Calibration Models Comparison $(n=194)$} \\
\hline Variable & OLS Model & GWR Model (full) & GWR Model (final) \\
\hline Moran's Index & 0.14 & 0.089 & 0.017 \\
\hline z-score & 3.34 & 2.12 & 0.49 \\
\hline Pattern & Clustered & Clustered & Random \\
\hline \multicolumn{4}{|c|}{ HUC12 Glacier Percent Area Validation Models Comparison $(n=63)$} \\
\hline Variable & OLS Model & GWR Model (full) & GWR Model (final) \\
\hline Moran's Index & -0.16 & -0.17 & -0.15 \\
\hline z-score & -1.57 & -1.80 & -1.53 \\
\hline Pattern & Random & Dispersed & Random \\
\hline \multicolumn{4}{|c|}{ HUC12 Glacier Percent Area Global Models Comparison $(n=257)$} \\
\hline Variable & OLS Model & GWR Model (full) & GWR Model (final) \\
\hline Moran's Index & 0.12 & 0.077 & 0.014 \\
\hline z-score & 3.31 & 2.24 & 0.52 \\
\hline Pattern & Clustered & Clustered & Random \\
\hline
\end{tabular}


Table 16: Chapter 3 rock glacier OLS and GWR calibration, validation and global model comparisons overview.

\begin{tabular}{|c|c|c|}
\hline \multicolumn{3}{|c|}{ HUC12 Rock Glacier Percent Area Calibration Models Comparison $(n=1144)$} \\
\hline Variable & OLS Model & GWR Model \\
\hline Adjusted $\mathrm{R}^{2}$ & 0.23 & 0.41 \\
\hline $\mathrm{AICc}$ & -7335 & -7594 \\
\hline Intercept & -0.022 & -0.11 to 0.0021 \\
\hline Mean Spring Dewpoint & -0.0020 & -0.0096 to 0.000042 \\
\hline Slope Standard Deviation & 0.0015 & -0.0001 to 0.0079 \\
\hline \multicolumn{3}{|c|}{ HUC12 Rock Glacier Percent Area Validation Models Comparison $(n=379)$} \\
\hline Variable & OLS Model & GWR Model \\
\hline Adjusted $\mathrm{R}^{2}$ & 0.16 & 0.37 \\
\hline AICc & -2514 & -2570 \\
\hline Intercept & -0.014 & -0.086 to 0.023 \\
\hline Mean Spring Dewpoint & -0.0015 & -0.0077 to 0.0022 \\
\hline Slope Standard Deviation & 0.00097 & -0.0019 to 0.0062 \\
\hline \multicolumn{3}{|c|}{ HUC12 Rock Glacier Percent Area Global Models Comparison $(n=1523)$} \\
\hline Variable & OLS Model & GWR Model \\
\hline Adjusted $\mathrm{R}^{2}$ & 0.21 & 0.42 \\
\hline AlCc & -9842 & $-10,235$ \\
\hline Intercept & -0.020 & -0.12 to 0.0044 \\
\hline Mean Spring Dewpoint & -0.0019 & -0.0092 to 0.00073 \\
\hline Slope Standard Deviation & 0.0014 & -0.00042 to 0.0072 \\
\hline
\end{tabular}


Table 17: Global Moran's Index clustering statistics for Chapter 3 OLS and GWR rock glacier models standardized residuals. All metrics calculated using inverse distance squared weighting and row standardization.

\begin{tabular}{|c|c|c|}
\hline \multicolumn{3}{|c|}{ HUC12 Rock Glacier Percent Area Calibration Models Comparison $(n=1144)$} \\
\hline Variable & OLS Model & GWR Model \\
\hline Moran's Index & 0.22 & 0.060 \\
\hline z-score & 16.27 & 4.39 \\
\hline Pattern & Clustered & Clustered \\
\hline \multicolumn{3}{|c|}{ HUC12 Rock Glacier Percent Area Validation Models Comparison $(n=379)$} \\
\hline Variable & OLS Model & GWR Model \\
\hline Moran's Index & 0.15 & 0.017 \\
\hline z-score & 5.89 & -0.56 \\
\hline Pattern & Clustered & Random \\
\hline \multicolumn{3}{|c|}{ HUC12 Rock Glacier Percent Area Global Models Comparison $(n=1523)$} \\
\hline Variable & OLS Model & GWR Model \\
\hline Moran's Index & 0.24 & 0.064 \\
\hline z-score & 21.08 & 5.82 \\
\hline Pattern & Clustered & Clustered \\
\hline
\end{tabular}




\section{Chapter 4 Tables}

Table 18: Riparian zone topographic and climatic characteristics for 35 pairs of $500 \mathrm{~m}$ long glacier and rock glacier first-order meltwater stream segments. Paired t-tests show only three significant differences between glacier types, indicating that glacier meltwater streams selected for riparian vegetation analysis may receive slightly more precipitation than the rock glacier streams they are compared to. However, these three variables are all derived from PRISM 1981 - 2010 climate normals (800 meter rasters) and as such should be considered accordingly given the coarse spatial resolution relative to the $500 \mathrm{~m}$ long stream segments evaluated. Statistical significance notation: $p$-values $>0.1=n$.s., $p$-values $<0.1={ }^{*}$, $p$-values $<0.05={ }^{* *}, p$-value $<0.01={ }^{* * *}$.

\begin{tabular}{|c|c|c|c|}
\hline Variable & $\begin{array}{c}\text { Glacier } \\
\text { Riparian Zones } \\
(\text { Mean } \pm 95 \% \mathrm{Cl})\end{array}$ & $\begin{array}{c}\text { Rock Glacier } \\
\text { Riparian Zones } \\
\text { (Mean } \pm 95 \% \mathrm{Cl} \text { ) }\end{array}$ & $\begin{array}{c}\text { Rock Glacier } \\
\text { Riparian Zones } \\
\% \text { Difference } \\
(95 \% \text { Cl estimate }(p \text {-value }))\end{array}$ \\
\hline Elevation (m) & $2669.7( \pm 242.1)$ & $2621.8( \pm 225.2)$ & -47.96 (n.s.) \\
\hline Slope $\left(^{\circ}\right)$ & $20.7( \pm 3.4)$ & $19.6( \pm 2.7)$ & -1.17 (n.s.) \\
\hline Northness & $0.08( \pm 0.06)$ & $0.11( \pm 0.07)$ & 0.04 (n.s.) \\
\hline Eastness & $-0.00( \pm 0.06)$ & $-0.10( \pm 0.08)$ & -0.10 (n.s.) \\
\hline $\begin{array}{l}\text { Solar Radiation } \\
\left(\mathrm{Wh}^{*} \mathrm{~m}^{2}\right)\end{array}$ & $98,542.3( \pm 9350.5)$ & $\begin{array}{r}101,707.3( \pm \\
9408.6)\end{array}$ & 3164.97 (n.s.) \\
\hline Precipitation (mm) & $133.7( \pm 17.1)$ & $117.6( \pm 14.2)$ & $-16.01(* * *)$ \\
\hline Snowfall $\left(\mathrm{mm} \mathrm{H}_{2} \mathrm{O}\right)$ & $88.8( \pm 11.5)$ & $74.2( \pm 10.2)$ & $-14.58(* * *)$ \\
\hline Mean Dewpoint $\left({ }^{\circ} \mathrm{C}\right)$ & $-7.2( \pm 0.8)$ & $-6.7( \pm 0.7)$ & $0.49\left(^{* * *}\right)$ \\
\hline Max Air Temp $\left({ }^{\circ} \mathrm{C}\right)$ & $5.4( \pm 0.5)$ & $5.9( \pm 0.4)$ & 0.43 (n.s.) \\
\hline Mean Air Temp $\left({ }^{\circ} \mathrm{C}\right)$ & $0.2( \pm 0.7)$ & $0.6( \pm 0.5)$ & 0.44 (n.s.) \\
\hline Min Air Temp $\left({ }^{\circ} \mathrm{C}\right)$ & $-5.1( \pm 0.9)$ & $-4.6( \pm 0.7)$ & 0.45 (n.s.) \\
\hline $\begin{array}{l}\text { Max Vapor Pressure } \\
\text { Deficit }(\mathrm{hPa})\end{array}$ & $6.7( \pm 0.3)$ & $7.0( \pm 0.3)$ & 0.24 (n.s.) \\
\hline $\begin{array}{l}\text { Mean Vapor Pressure } \\
\text { Deficit (hPa) }\end{array}$ & $4.1( \pm 0.2)$ & $4.2( \pm 0.1)$ & 0.12 (n.s.) \\
\hline $\begin{array}{l}\text { Min Vapor Pressure } \\
\text { Deficit (hPa) }\end{array}$ & $1.4( \pm 0.1)$ & $1.4( \pm 0.1)$ & 0.01 (n.s.) \\
\hline
\end{tabular}


Table 19: Riparian zone percent cover characteristics for individual NLCD 2011 classes, as well as a single "combined vegetated" class, along 35 pairs of $500 \mathrm{~m}$ long glacier and rock glacier first-order meltwater stream segments. For each glacier type a total of $17.5 \mathrm{~km}$ of meltwater stream channel and $0.525 \mathrm{~km}^{2}$ of riparian zone was evaluated. Paired t-tests show large significant differences in total "combined vegetated" cover between glacier types, but when evaluated individually only two NLCD 2011 classes are shown to differ significantly between glacier types. Statistical significance notation: $p$-values $>0.1=n . s$., $p$-values $<0.1={ }^{*}, p$-values $<$ $0.05=* *$, $p$-value $<0.01=* * *$.

\begin{tabular}{|c|c|c|c|}
\hline $\begin{array}{l}2011 \text { NLCD } \\
\text { Land Cover }\end{array}$ & $\begin{array}{c}\text { Glacier } \\
\text { Riparian Zones } \\
\text { (Mean \% Cover } \pm \\
95 \% \mathrm{Cl} \text { ) }\end{array}$ & $\begin{array}{c}\text { Rock Glacier } \\
\text { Riparian Zones } \\
\text { (Mean \% Cover } \pm 95 \% \mathrm{Cl} \text { ) }\end{array}$ & $\begin{array}{c}\text { Rock Glacier } \\
\text { Riparian Zones } \\
\% \text { Difference } \\
(95 \% \text { Cl estimate }(p-\text { value }))\end{array}$ \\
\hline Snow & $3.7 \% \pm 4.7 \%$ & $3.1 \% \pm 4.8 \%$ & $-0.6 \%$ (n.s.) \\
\hline Barren & $31.8 \% \pm 10.1 \%$ & $10.7 \% \pm 7.7 \%$ & $-21.1 \%\left(^{* * *}\right)$ \\
\hline $\begin{array}{l}\text { Deciduous } \\
\text { Forest }\end{array}$ & $0.8 \% \pm 1.1 \%$ & $0.0 \% \pm 0.0 \%$ & $-0.8 \%$ (n.s.) \\
\hline $\begin{array}{l}\text { Evergreen } \\
\text { Forest }\end{array}$ & $14.3 \% \pm 8.9 \%$ & $37.1 \% \pm 13.7 \%$ & $22.8 \%\left(^{* * *}\right)$ \\
\hline $\begin{array}{l}\text { Mixed } \\
\text { Forest }\end{array}$ & $0.0 \% \pm 0.0 \%$ & $0.5 \% \pm 0.9 \%$ & $0.5 \%$ (n.s.) \\
\hline Shrub Scrub & $25.3 \% \pm 10.4 \%$ & $22.7 \% \pm 8.7 \%$ & $-1.3 \%$ (n.s.) \\
\hline Herbaceous & $22.1 \% \pm 9.3 \%$ & $25.6 \% \pm 11.2 \%$ & $0.2 \%$ (n.s.) \\
\hline $\begin{array}{l}\text { Woody } \\
\text { Wetland }\end{array}$ & $0.0 \% \pm 0.0 \%$ & $0.3 \% \pm 0.7 \%$ & $0.3 \%$ (n.s.) \\
\hline $\begin{array}{l}\text { Combined } \\
\text { Vegetated }\end{array}$ & $64.5 \% \pm 10.9 \%$ & $86.2 \% \pm 11.2 \%$ & $21.7 \%\left(^{* * *}\right)$ \\
\hline
\end{tabular}


Table 20: Meltwater stream riparian vegetation cover OLS model summary. Rock glaciers as the cryospheric meltwater source are positively associated with increased riparian cover. Cool, wet spring conditions and low humidity winter conditions exhibit a negative influence.

\begin{tabular}{|l|r|}
\hline \multicolumn{2}{|c|}{ Riparian Vegetation Cover Model } \\
\hline Adjusted $R^{2}$ & 0.50 \\
\hline Intercept & 1.72 \\
\hline V1: Mean Spring Snow & -0.005 \\
\hline V2: Maximum Winter Vapor Pressure Deficit & -0.241 \\
\hline V3: Rock Glacier Meltwater Source & 0.136 \\
\hline
\end{tabular}


Table 21: Glacier and rock glacier meltwater stream riparian vegetation density by growing season. In all growing seasons evaluated, rock glacier meltwater stream riparian vegetation density was significantly greater than glacier meltwater stream riparian vegetation density. The largest difference was observed during the 2015 growing season (glacier mean NDVI $=0.192$, rock glacier mean $N D V I=0.377$, difference $=0.185$ ), while the smallest difference was observed during the 2016 growing season (glacier mean NDVI $=0.102$, rock glacier mean NDVI $=0.240$, difference $=0.138$ ). Statistical significance notation: $p$-values $>0.1=n$.s., $p$-values $<0.1={ }^{*}, p$ values $<0.05=* *$, $p$-value $<0.01=* * *$.

\begin{tabular}{|c|c|c|c|}
\hline Year & $\begin{array}{c}\text { Glacier } \\
\text { Riparian Zones } \\
(\text { Mean NDVI } \pm 95 \% \mathrm{Cl}))\end{array}$ & $\begin{array}{c}\text { Rock Glacier } \\
\text { Riparian Zones } \\
(\text { Mean NDVI } \pm 95 \% \mathrm{Cl}))\end{array}$ & $\begin{array}{c}\text { Rock Glacier } \\
\text { Riparian Zones } \\
\text { NDVI Difference } \\
(95 \% \text { Cl estimate ( } p \text {-value }))\end{array}$ \\
\hline 2013 & $0.125( \pm 0.029)$ & $0.299( \pm 0.045)$ & $0.174\left(^{* * *}\right)$ \\
\hline 2014 & $0.108( \pm 0.028)$ & $0.279( \pm 0.046)$ & $0.171^{(* * *)}$ \\
\hline 2015 & $0.192( \pm 0.024)$ & $0.377( \pm 0.033)$ & $0.185\left(^{* * *}\right)$ \\
\hline 2016 & $0.102( \pm 0.025)$ & $0.240( \pm 0.036)$ & $0.138\left(^{* * *}\right)$ \\
\hline 2017 & $0.122( \pm 0.029)$ & $0.281( \pm 0.046)$ & $0.159\left(^{(* * *)}\right.$ \\
\hline All Years & $0.134( \pm 0.012)$ & $0.299( \pm 0.018)$ & $0.165\left(^{* * *}\right)$ \\
\hline
\end{tabular}


Table 22: Glacier and rock glacier meltwater stream riparian vegetation density by stream pair. At all but four stream pairs, rock glacier meltwater stream riparian vegetation density was significantly greater than glacier meltwater stream riparian vegetation density. Statistical significance notation: $p$-values $>0.1=n$.s., $p$-values $<0.1={ }^{*}, p$-values $<0.05={ }^{* *}$, $p$-value $<$ $0.01={ }^{* * *}$.

\begin{tabular}{|c|c|c|c|}
\hline Stream Pair & $\begin{array}{c}\text { Glacier } \\
\text { Riparian Zone } \\
\text { (Mean NDVI } \pm 95 \% \mathrm{Cl} \text { ) }\end{array}$ & $\begin{array}{c}\text { Rock Glacier } \\
\text { Riparian Zone } \\
(\text { Mean NDVI } \pm 95 \% \mathrm{Cl})\end{array}$ & $\begin{array}{c}\text { Rock Glacier } \\
\text { Riparian Zone } \\
\text { NDVI Difference ( } p \text {-value) }\end{array}$ \\
\hline $01(C A)$ & $0.021 \pm 0.027$ & $0.023 \pm 0.025$ & 0.002 (n.s.) \\
\hline 02(CA) & $0.006 \pm 0.023$ & $0.144 \pm 0.059$ & $0.138\left(^{* * *}\right)$ \\
\hline $03(\mathrm{CA})$ & $-0.038 \pm 0.015$ & $-0.009 \pm 0.019$ & $0.029\left({ }^{* * *}\right)$ \\
\hline 04(CO & $0.102 \pm 0.053$ & $0.15 \pm 0.0680$ & $0.048\left(^{* * *}\right)$ \\
\hline 05(MT) & $0.052 \pm 0.035$ & $0.264 \pm 0.068$ & $0.212(* * *)$ \\
\hline 06(MT) & $0.196 \pm 0.065$ & $0.380 \pm 0.103$ & $\left.0.184{ }^{(* * *}\right)$ \\
\hline 07(MT) & $0.402 \pm 0.105$ & $0.493 \pm 0.107$ & $\left.0.0911^{* * *}\right)$ \\
\hline 08(MT) & $0.095 \pm 0.052$ & $0.140 \pm 0.084$ & $0.045\left(^{* * *}\right)$ \\
\hline 09(MT) & $0.087 \pm 0.058$ & $0.589 \pm 0.120$ & $0.502\left(^{* * *}\right)$ \\
\hline 10(MT) & $0.133 \pm 0.056$ & $0.289 \pm 0.077$ & $0.156\left(^{* * *}\right)$ \\
\hline 11(MT) & $0.208 \pm 0.060$ & $0.541 \pm 0.074$ & $0.333(* * *)$ \\
\hline 12(MT) & $0.080 \pm 0.037$ & $0.645 \pm 0.095$ & $0.565\left(^{* * *}\right)$ \\
\hline 13(MT) & $0.231 \pm 0.054$ & $0.284 \pm 0.064$ & $0.053\left({ }^{* * *}\right)$ \\
\hline 14(MT) & $0.161 \pm 0.054$ & $0.553 \pm 0.054$ & $0.392\left(^{* * *}\right)$ \\
\hline 14(MT) & $0.162 \pm 0.061$ & $0.428 \pm 0.085$ & $0.266\left(^{* * *}\right)$ \\
\hline 15(WA) & $0.278 \pm 0.072$ & $0.384 \pm 0.077$ & $0.106\left(^{* * *}\right)$ \\
\hline 16(WA) & $0.057 \pm 0.027$ & $0.578 \pm 0.100$ & $0.521\left(^{* * *}\right)$ \\
\hline 17(WA) & $0.503 \pm 0.120$ & $0.668 \pm 0.144$ & $0.165\left(^{* * *}\right)$ \\
\hline 18(WA) & $0.309 \pm 0.085$ & $0.475 \pm 0.140$ & $0.166\left(^{* * *}\right)$ \\
\hline 19(WA) & $0.198 \pm 0.066$ & $0.622 \pm 0.094$ & $\left.0.424{ }^{* * *}\right)$ \\
\hline $20(W Y)$ & $0.042 \pm 0.019$ & $0.109 \pm 0.037$ & $0.067\left(^{* * *}\right)$ \\
\hline $21(\mathrm{WY})$ & $0.001 \pm 0.019$ & $0.338 \pm 0.080$ & $0.337\left(^{* * *}\right)$ \\
\hline 22(WY) & $0.164 \pm 0.060$ & $0.011 \pm 0.026$ & $-0.153\left({ }^{* * *}\right)$ \\
\hline $23(\mathrm{WY})$ & $0.065 \pm 0.040$ & $0.197 \pm 0.065$ & $0.132\left(^{* * *}\right)$ \\
\hline $24(\mathrm{WY})$ & $0.060 \pm 0.036$ & $0.469 \pm 0.080$ & $0.409\left(^{* * *}\right)$ \\
\hline 25(WY) & $0.121 \pm 0.040$ & $0.275 \pm 0.082$ & $0.154\left(^{* * *}\right)$ \\
\hline $26(\mathrm{WY})$ & $0.362 \pm 0.083$ & $0.091 \pm 0.034$ & $-0.271\left(^{* * *}\right)$ \\
\hline 28(WY) & $-0.013 \pm 0.014$ & $0.159 \pm 0.064$ & $0.172\left(^{* * *}\right)$ \\
\hline
\end{tabular}




\begin{tabular}{|c|c|c|c|}
\hline Stream Pair & $\begin{array}{c}\text { Glacier } \\
\text { Riparian Zone } \\
(\text { Mean NDVI } \pm 95 \% \mathrm{Cl})\end{array}$ & $\begin{array}{c}\text { Rock Glacier } \\
\text { Riparian Zone } \\
(\text { Mean NDVI } \pm 95 \% \mathrm{Cl})\end{array}$ & $\begin{array}{c}\text { Rock Glacier } \\
\text { Riparian Zone } \\
\text { NDVI Difference ( } p \text {-value) }\end{array}$ \\
\hline 29(WY) & $0.369 \pm 0.089$ & $0.109 \pm 0.026$ & $-0.260\left(^{* * *}\right)$ \\
\hline 30(WY) & $-0.011 \pm 0.019$ & $0.485 \pm 0.078$ & $0.496\left(^{* * *}\right)$ \\
\hline $31(\mathrm{WY})$ & $0.037 \pm 0.042$ & $0.109 \pm 0.083$ & $0.072\left(^{* * *}\right)$ \\
\hline 32(WY) & $0.189 \pm 0.066$ & $0.222 \pm 0.066$ & $0.033\left(^{* * *}\right)$ \\
\hline 33(WY) & $0.059 \pm 0.028$ & $0.135 \pm 0.054$ & $0.076\left(^{* * *}\right)$ \\
\hline 34(WY) & $0.169 \pm 0.059$ & $0.235 \pm 0.076$ & $0.066\left(^{* * *}\right)$ \\
\hline $35(\mathrm{WY})$ & $0.086 \pm 0.031$ & $0.107 \pm 0.038$ & $0.021\left(^{* * *}\right)$ \\
\hline ALL PAIRS & $0.134 \pm 0.012$ & $0.299 \pm 0.018$ & $0.165\left(^{* * *}\right)$ \\
\hline
\end{tabular}


Table 23: Meltwater stream riparian vegetation density OLS model summary. Rock glaciers as the cryospheric meltwater source are are positively associated with increased riparian vegetation. Warm, humid fall conditions also exhibit a positive influence.

\begin{tabular}{|l|r|}
\hline \multicolumn{2}{|c|}{ Riparian Vegetation Density Model } \\
\hline Adjusted $\mathrm{R}^{2}$ & 0.56 \\
\hline Intercept & 0.554 \\
\hline V1: Mean Fall Dewpoint & 0.044 \\
\hline V2: Rock Glacier Meltwater Source & 0.086 \\
\hline
\end{tabular}


Figures 
Chapter 2 Figures 


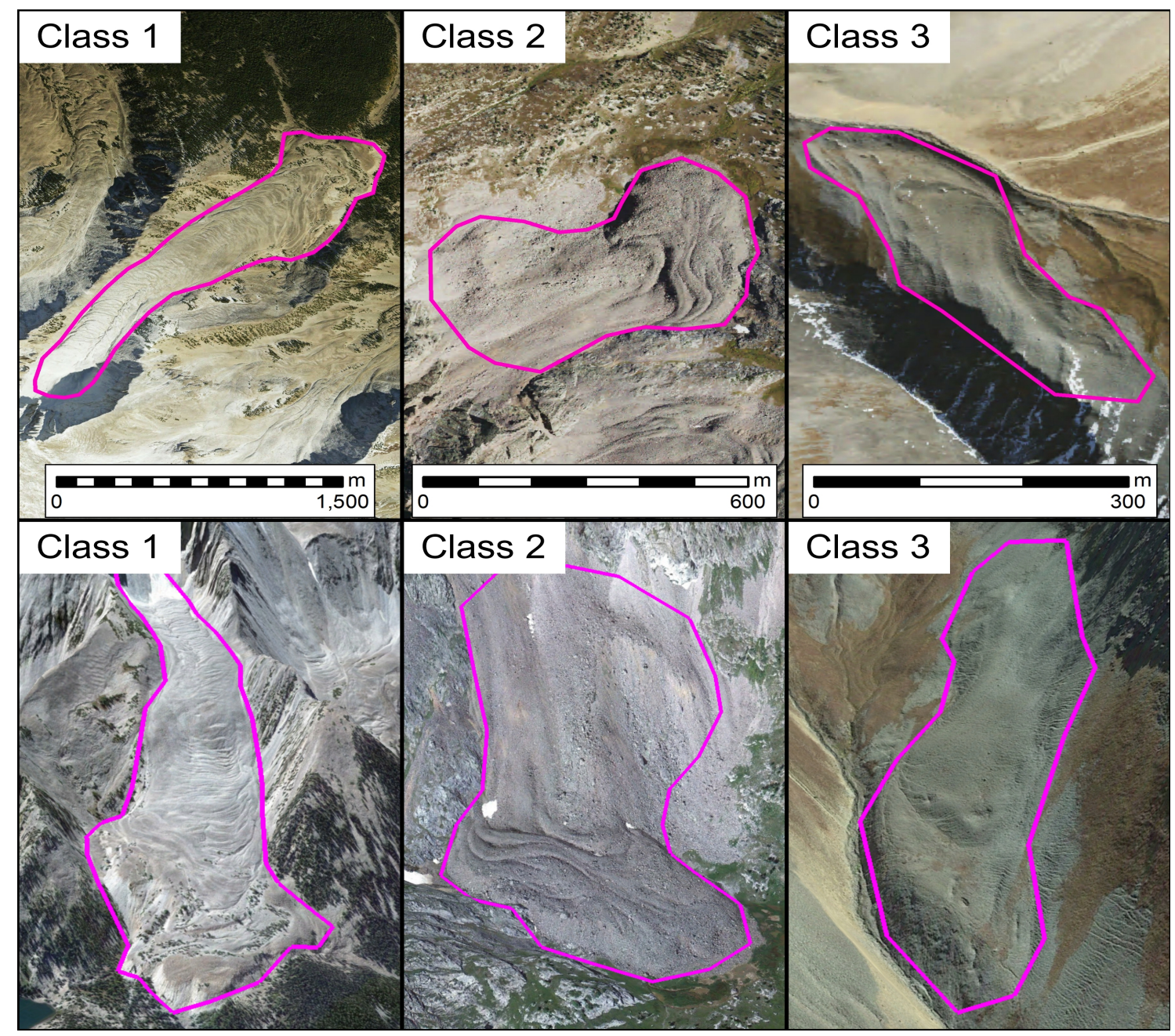

Figure 1: Examples of each of the three rock glacier classes shown in both plan view (top panels) and oblique upslope view (bottom panels). Leftmost panels show a Class 1: Highly active rock glacier exhibiting distinct, complex and extensive ridge and swale flow banding, significantly over-steepened terminal slopes, larger than $0.01 \mathrm{~km}^{2}$. Center panels show a Class 2: Intermediately active rock glacier, some pronounced ridge and swale flow banding, distinct marginal slopes, some over-steepened terminal slopes, larger than $0.01 \mathrm{~km}^{2}$. Rightmost panels show a Class 3: Minimally active rock glacier, may be a deflated Class 1 or 2 feature, sparse ridge and swale flow banding and some over-steepened terminal slopes, but not a classic pronival rampart. Note different scale bars for each plan view panel. Scale varies across images in oblique view panels. 


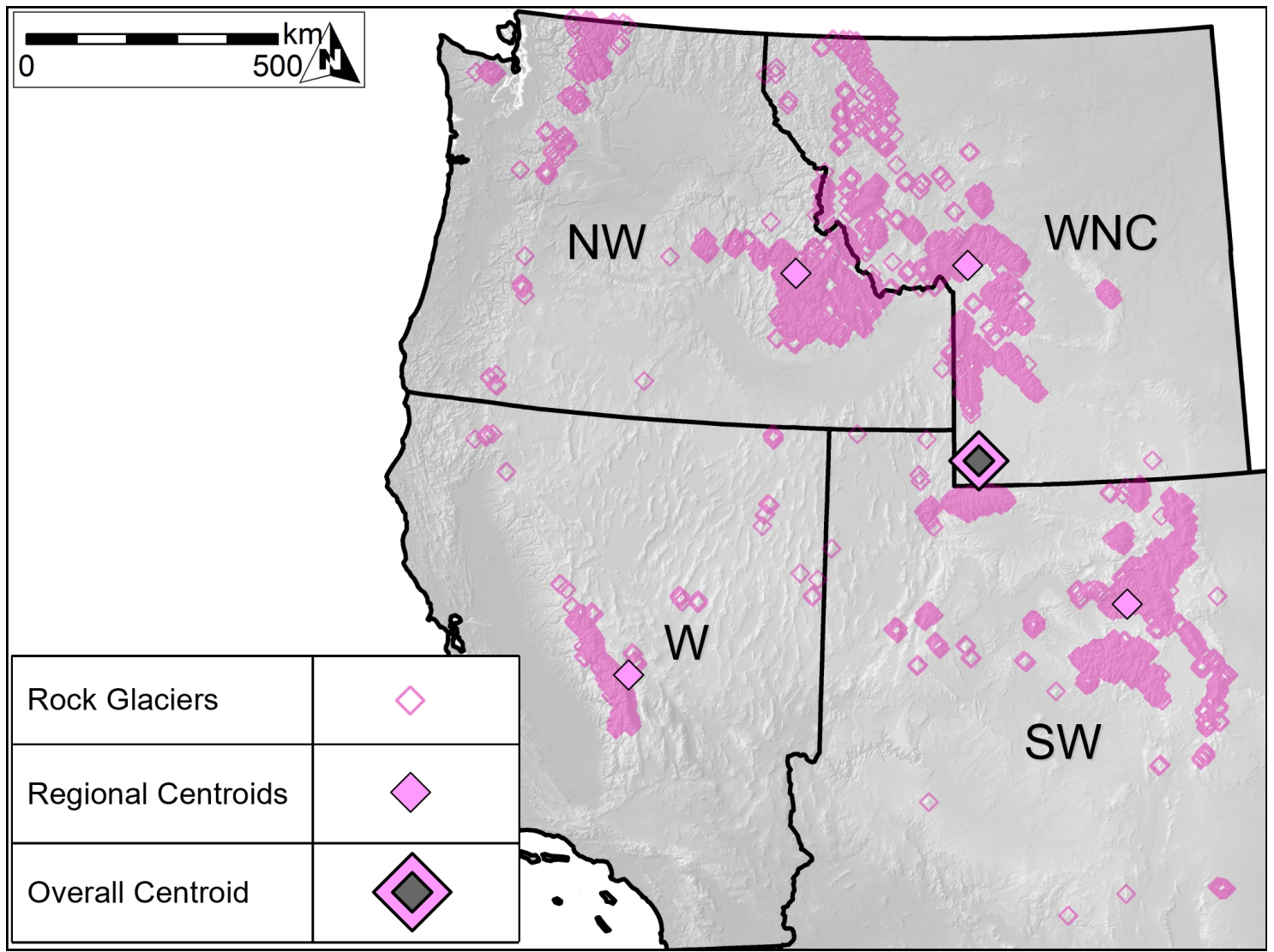

Figure 2: Locations of rock glacier inventory features $(n=10,343)$, as well as centroids for the entire inventory and NOAA Climate Region subsets. The largest rock glaciers, as well as highest rock glacier densities, are found in the relatively arid Southern Rocky Mountains. The Sierra Nevada of California and Uinta Mountains of Utah, climatologically similar to the Southern Rockies, also host large rock glaciers at high densities. Rock glaciers of the humid Cascade Mountains are smaller and less densely distributed, and only a few pockets of rock glaciers are found south of $35^{\circ} \mathrm{N}$ latitude. However, the western U.S. is a generally defined by mountainous, high elevation terrain, and rock glaciers are found in all 11 western states. 


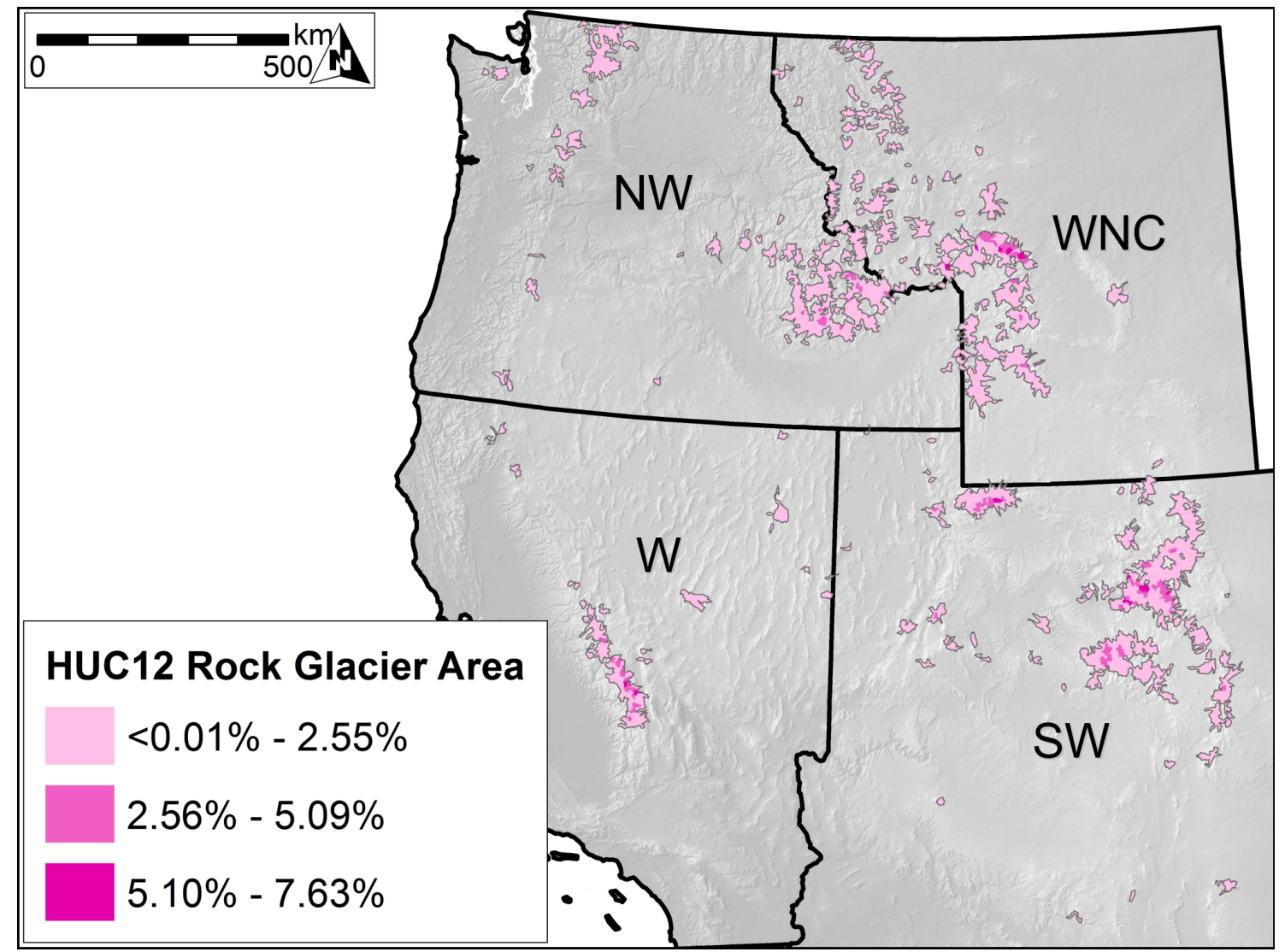

Figure 3: Rock glacier areas, as a percent of the HUC12 watersheds that contain them. 


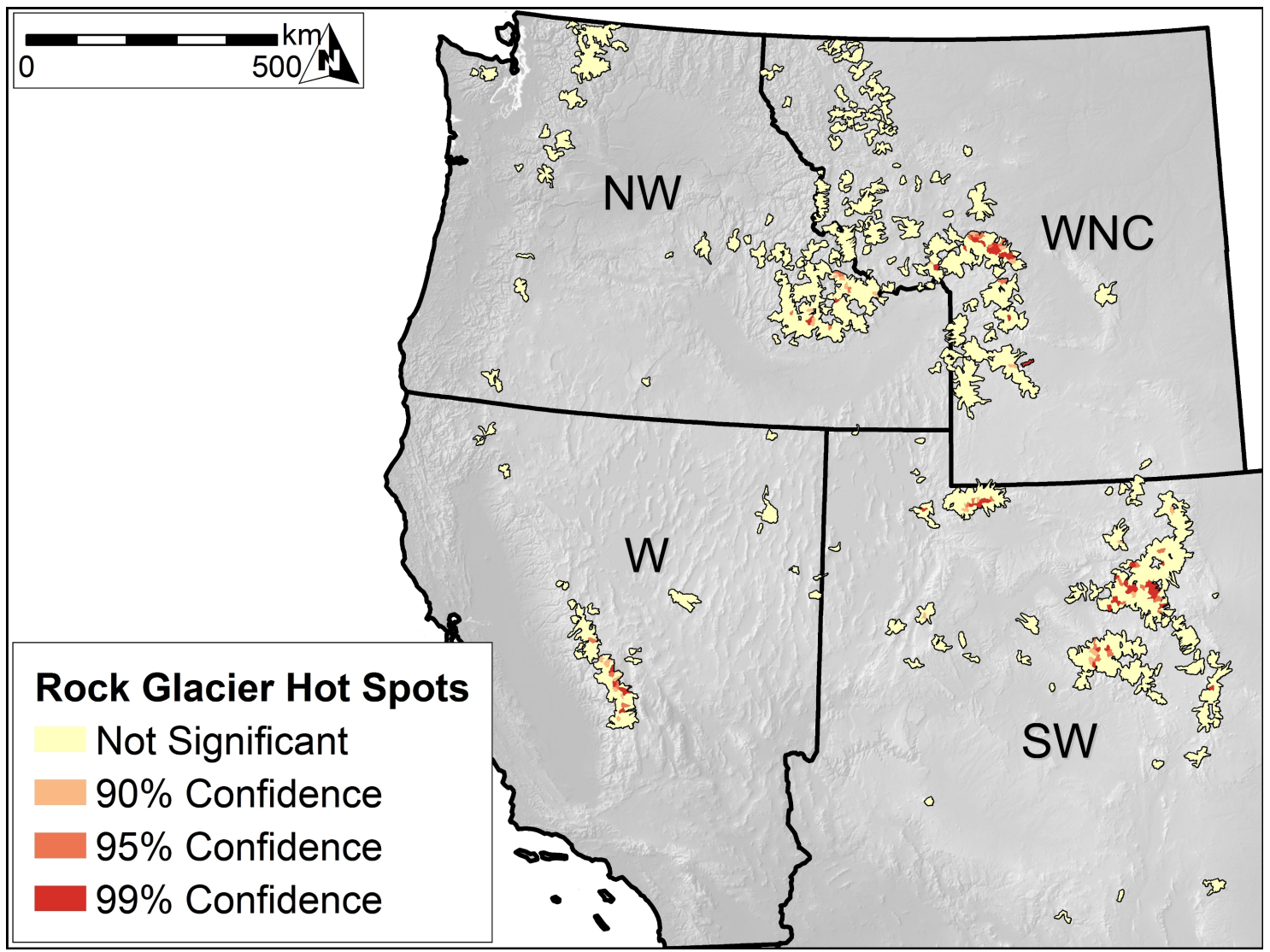

Figure 4: Statistically significant Getis-Ord $\mathrm{Gi}^{*}$ hot spots for rock glacier percent area at the HUC12 watershed level. Moran's I analysis shows rock glacier percent area is significantly clustered (Moran's Index $=0.27, z$-score $=22.35$ ). No statistically significant cold spots are observed. 

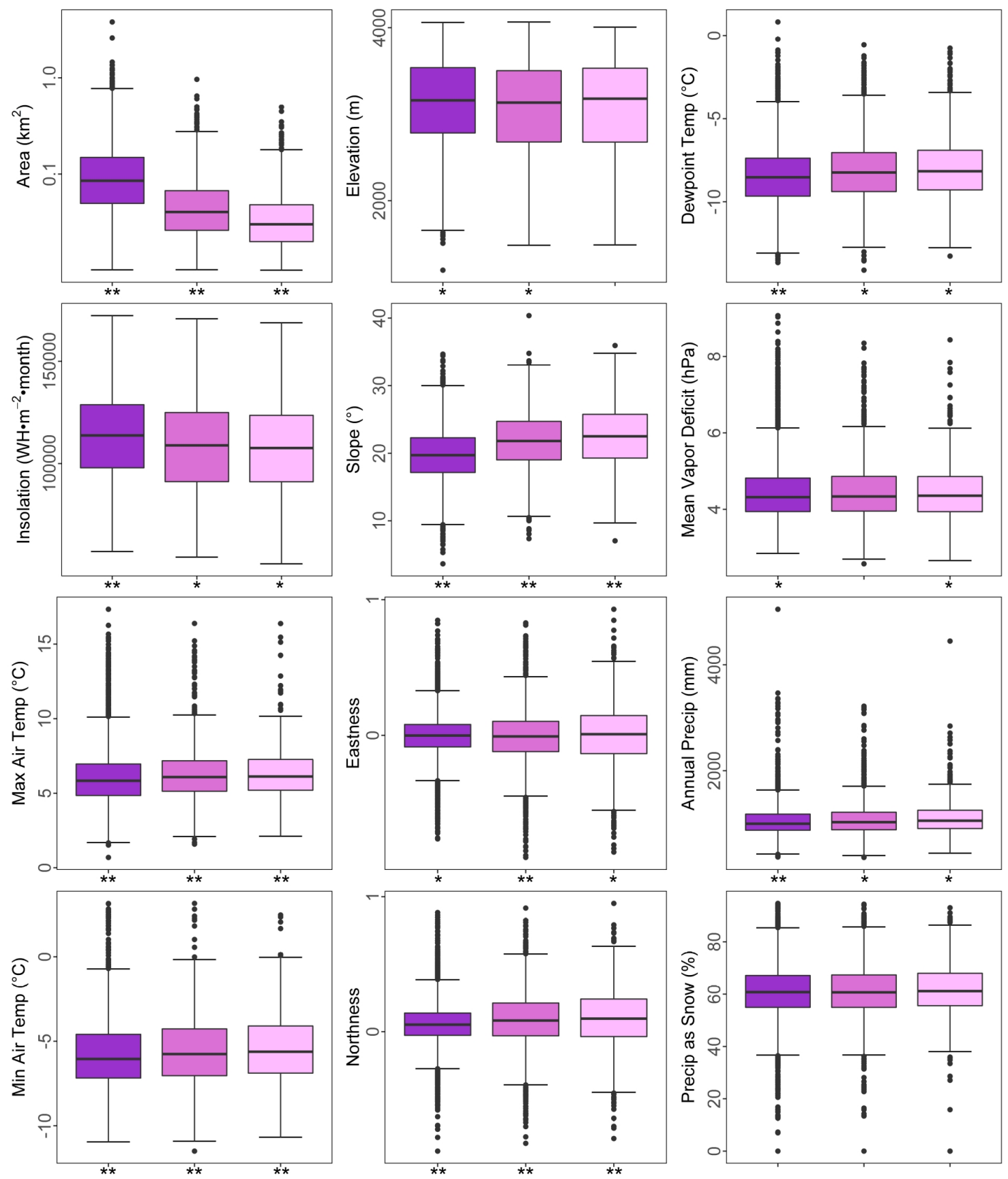

Figure 5: Geographic characteristics of Class 1 (purple, $n=7052$ ), Class 2 (magenta, $n=2416$ ) and Class 3 (pink, $n=875$ ) rock glaciers. Statistically significant differences (Tukey's HSD test, $\alpha=0.05$ ) are denoted with asterisks (different from both $={ }^{* *}$, different from one $={ }^{*}$ ). 



Figure 6: Geographic and atmospheric characteristics of rock glaciers by NOAA Climate Region. 


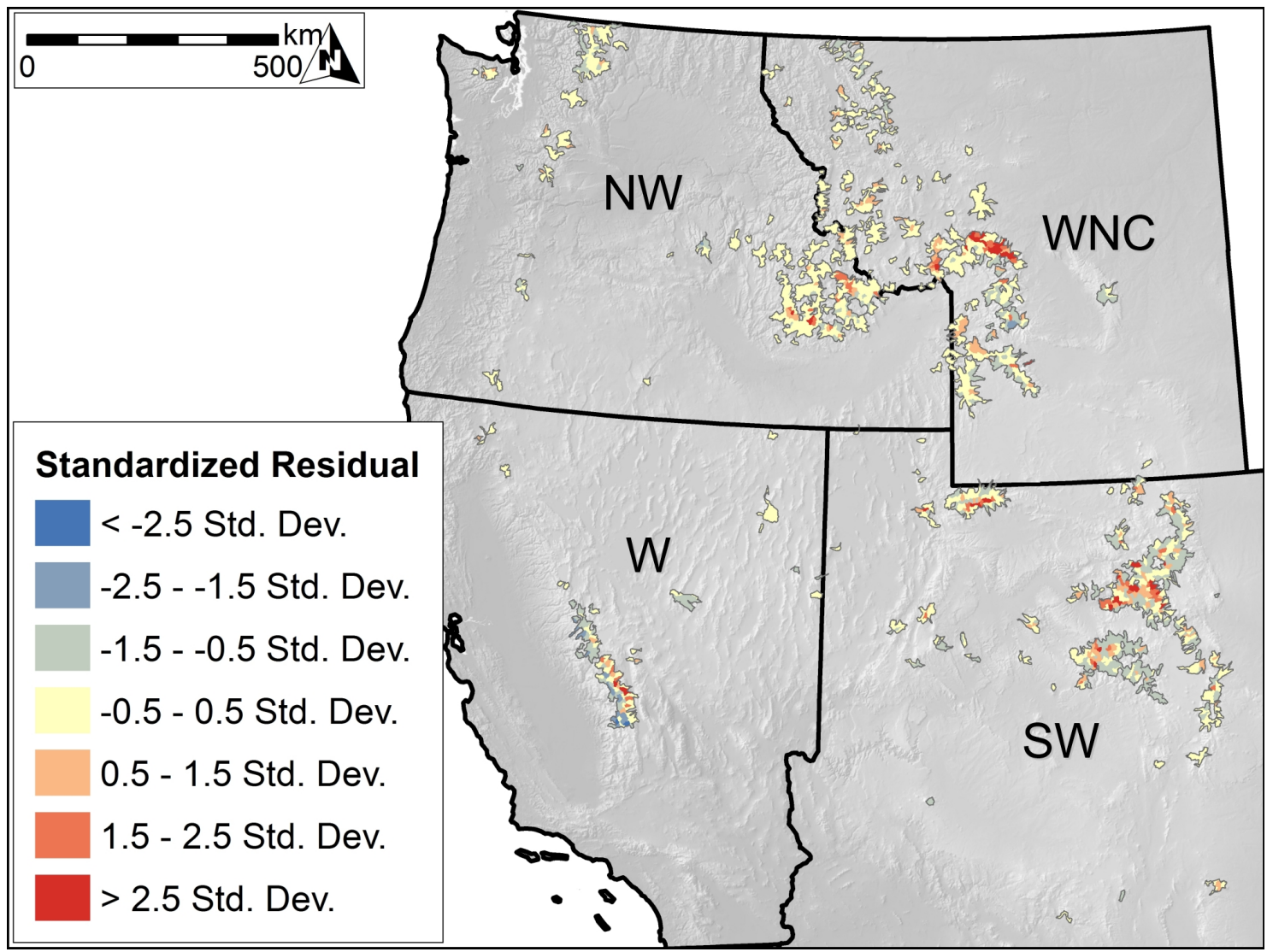

Figure 7: Standardized residuals for the Chapter 2 rock glacier OLS model. 


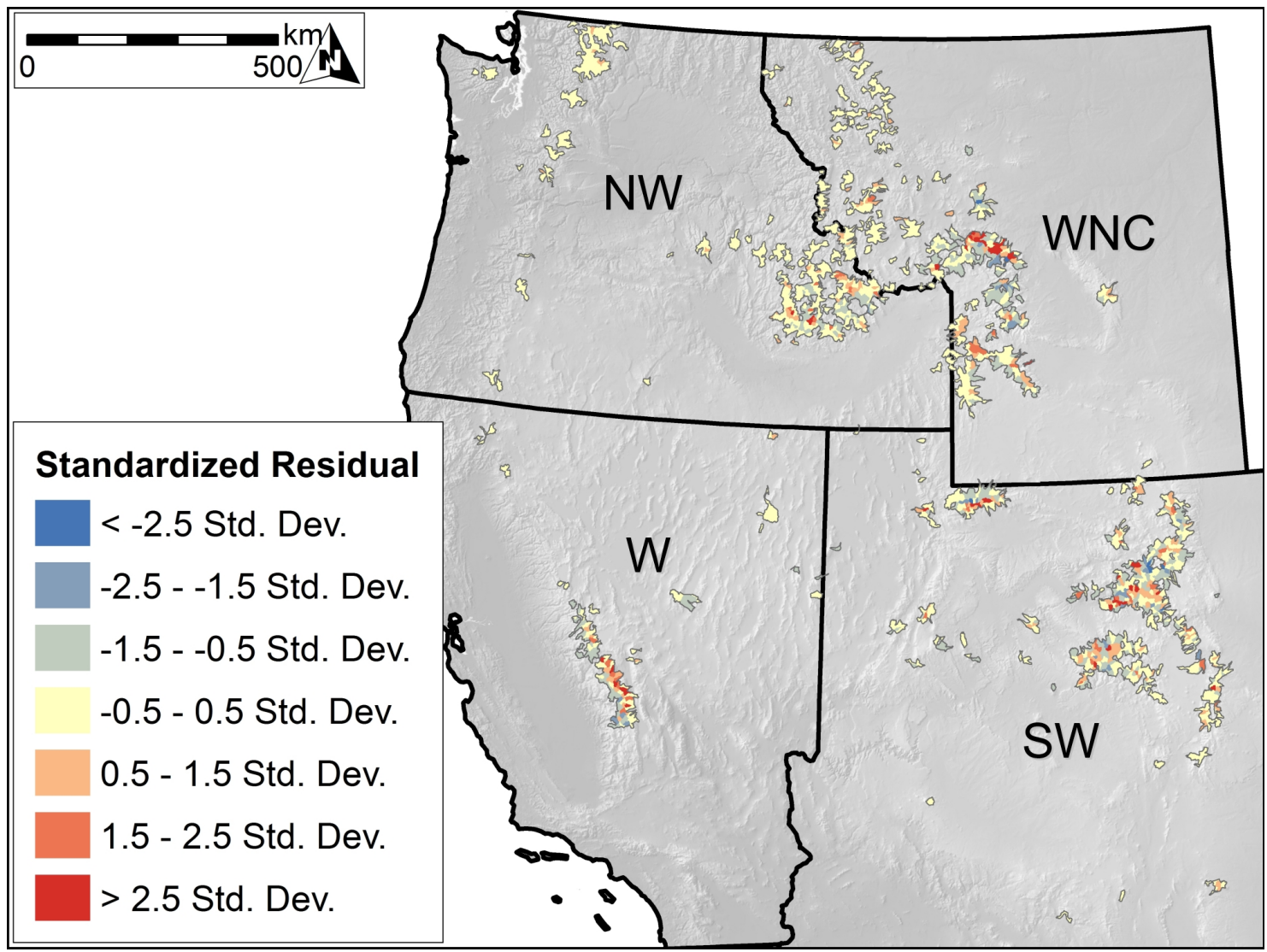

Figure 8: Standardized residuals for the Chapter 2 rock glacier final GWR model. 


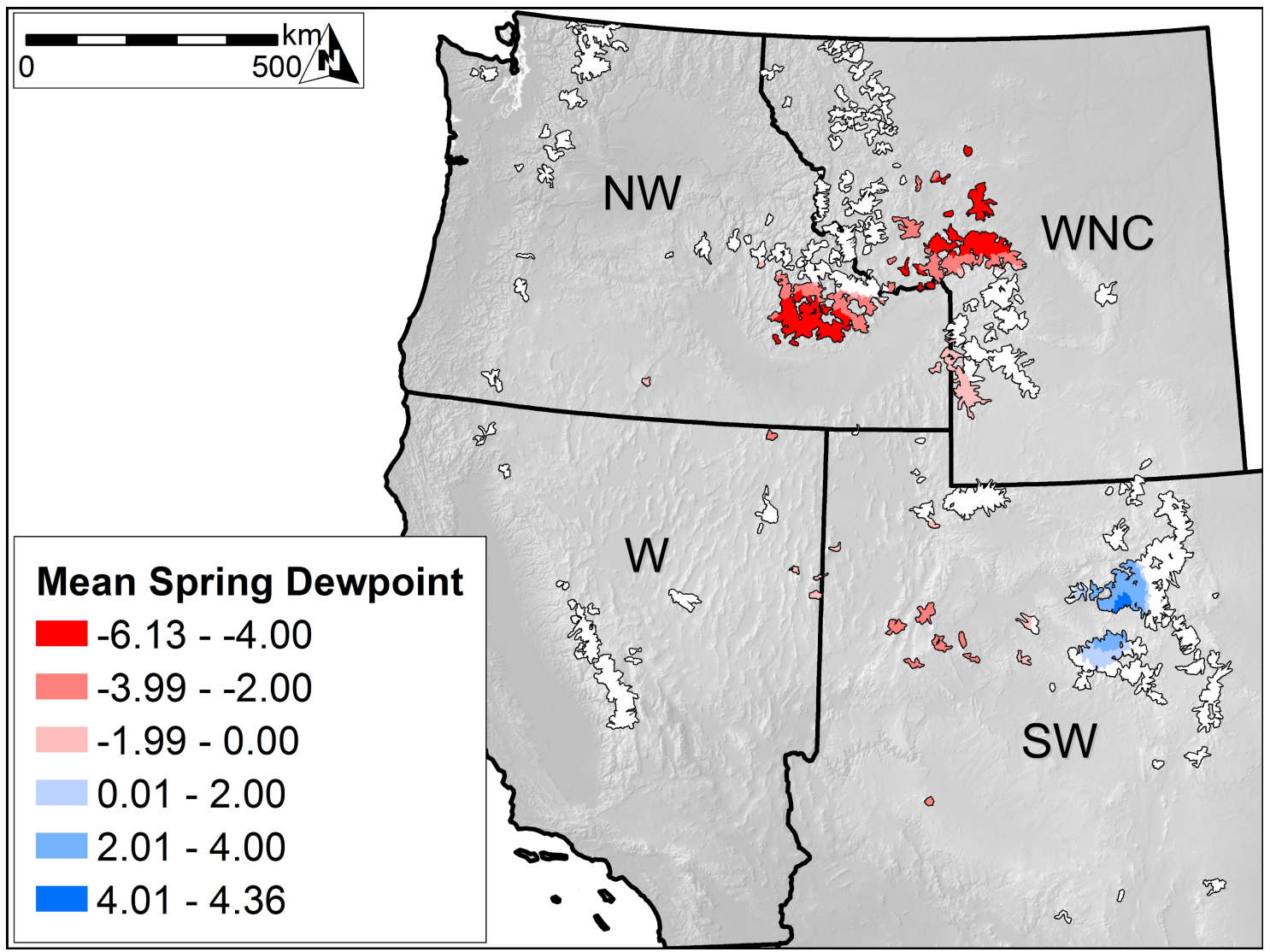

Figure 9: The Chapter 2 rock glacier final GWR model allows the coefficients for mean spring dewpoint to vary in sign. Of the 240 HUC12 watersheds where the coefficient is positive, the coefficient can confidently be shown to significantly differ from zero in the 122 mapped here. Of the 1283 HUC12 watersheds where the coefficient is negative, the coefficient can confidently be shown to significantly differ from zero in the 389 mapped here. Coefficients have been multiplied by 1000 for clarity. 


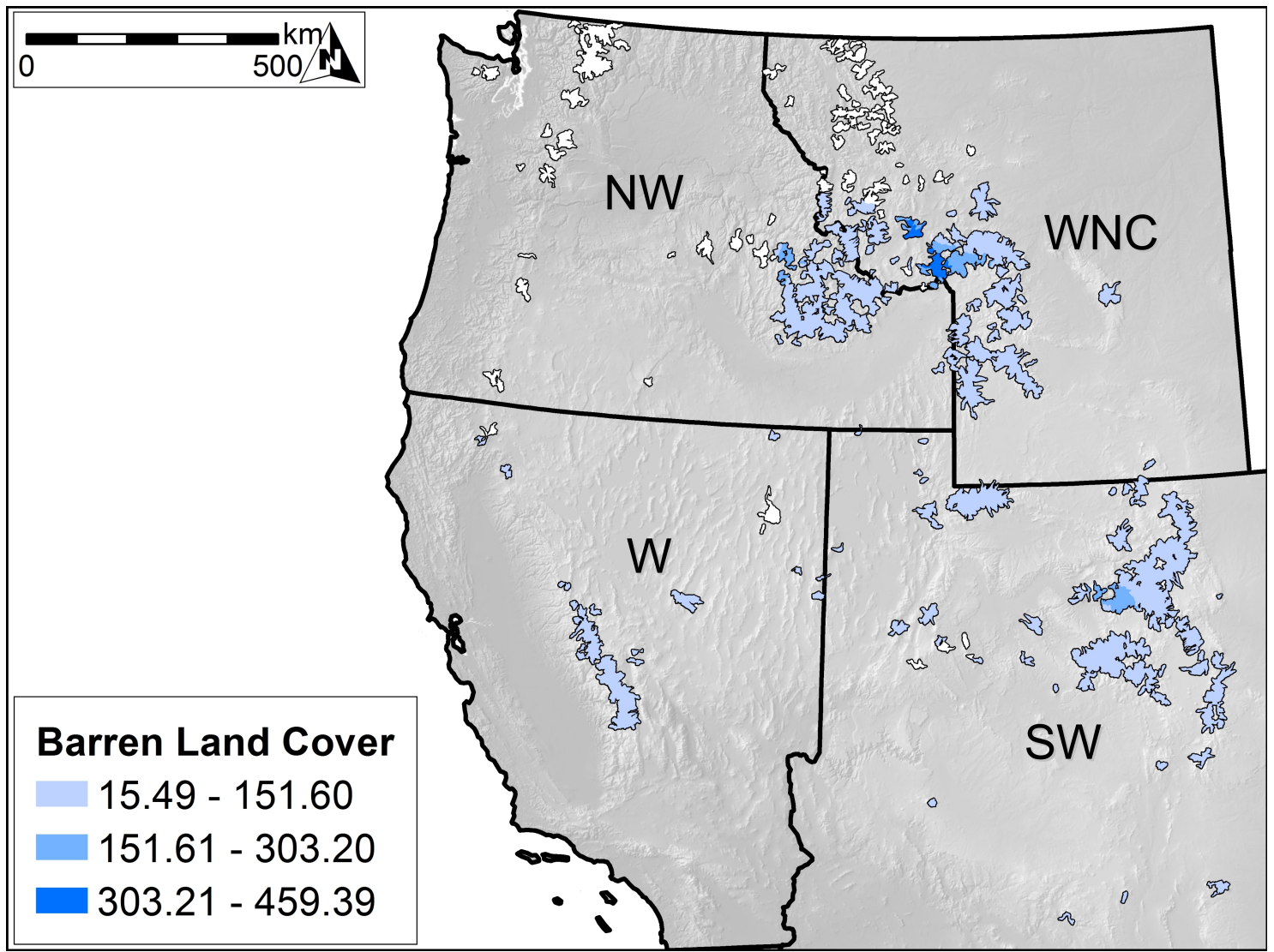

Figure 10: The Chapter 2 rock glacier final GWR model allows the coefficients for percent barren land cover to vary in sign. Of the 1463 HUC12 watersheds where the coefficient is positive, the coefficient can confidently be shown to significantly differ from zero in the 1254 mapped here. Of the 60 HUC12 watersheds where the coefficient is negative, the coefficient can confidently be shown to significantly differ from zero in none. Coefficients have been multiplied by 1000 for clarity. 
Chapter 3 Figures 


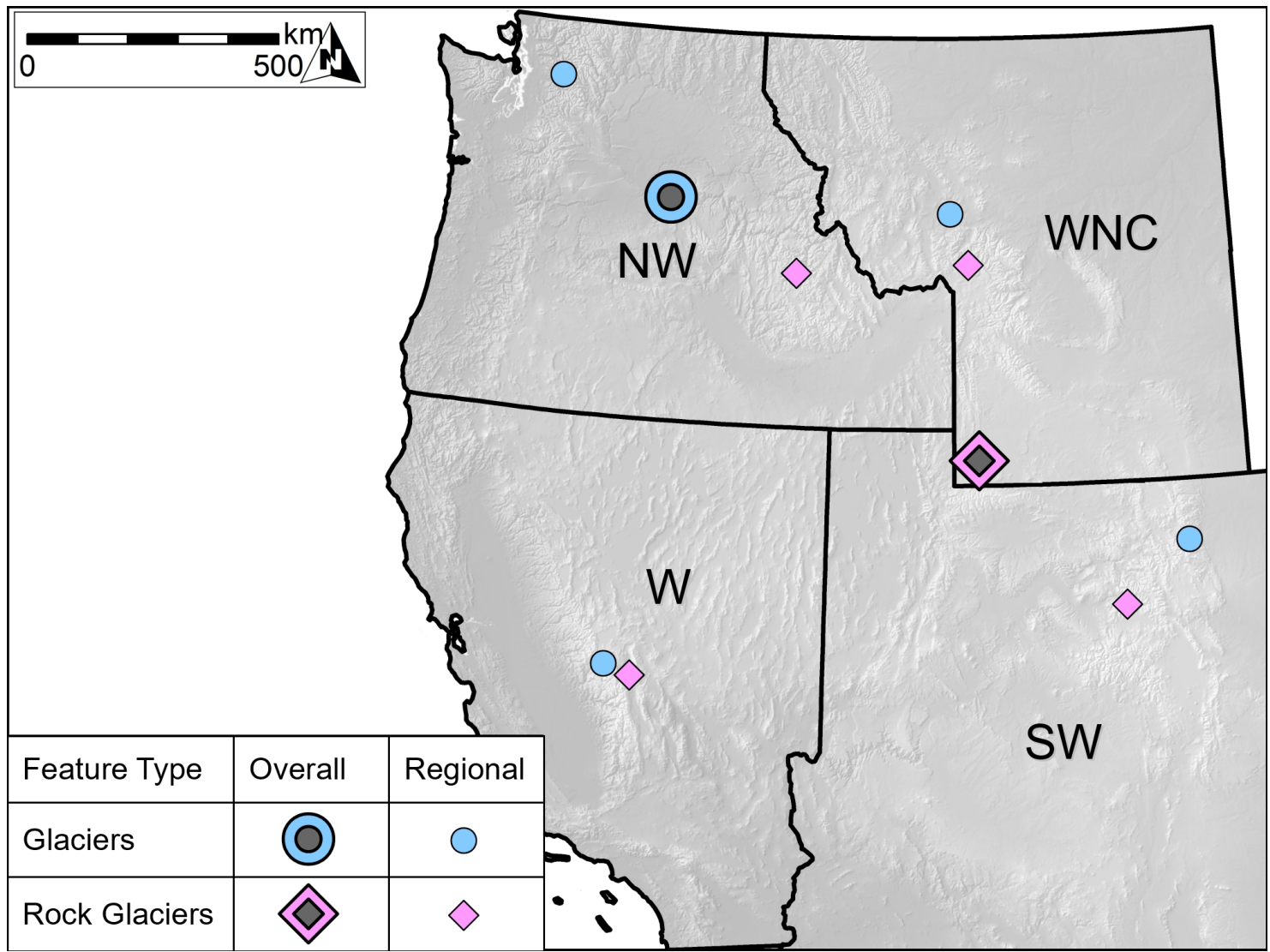

Figure 11: Locations of distribution centroids for glaciers $(n=853)$ and rock glaciers $(n=$ 10,343 ). Considering all features, distribution centroids align along continental precipitation and temperature gradients, from the cool and humid NW region towards the warm and arid SW region. The distribution of glaciers, which require the most precipitation and largest precipitation fraction as snow, is centered in Washington. The distribution of rock glaciers, which require the least precipitation and smallest precipitation fraction as snow, is centered in Wyoming. Analysis of distribution centroids by NOAA climate region shows that the two feature types are most geographically disparate in the NW region and most geographically concentrated in the W region. In the NW region virtually all rock glaciers are found in the Sawtooth Range in central ID and virtually all glaciers are found in the Cascade Range in northern Washington. In the W region virtually all features of both type are found in the Sierra Nevada. 


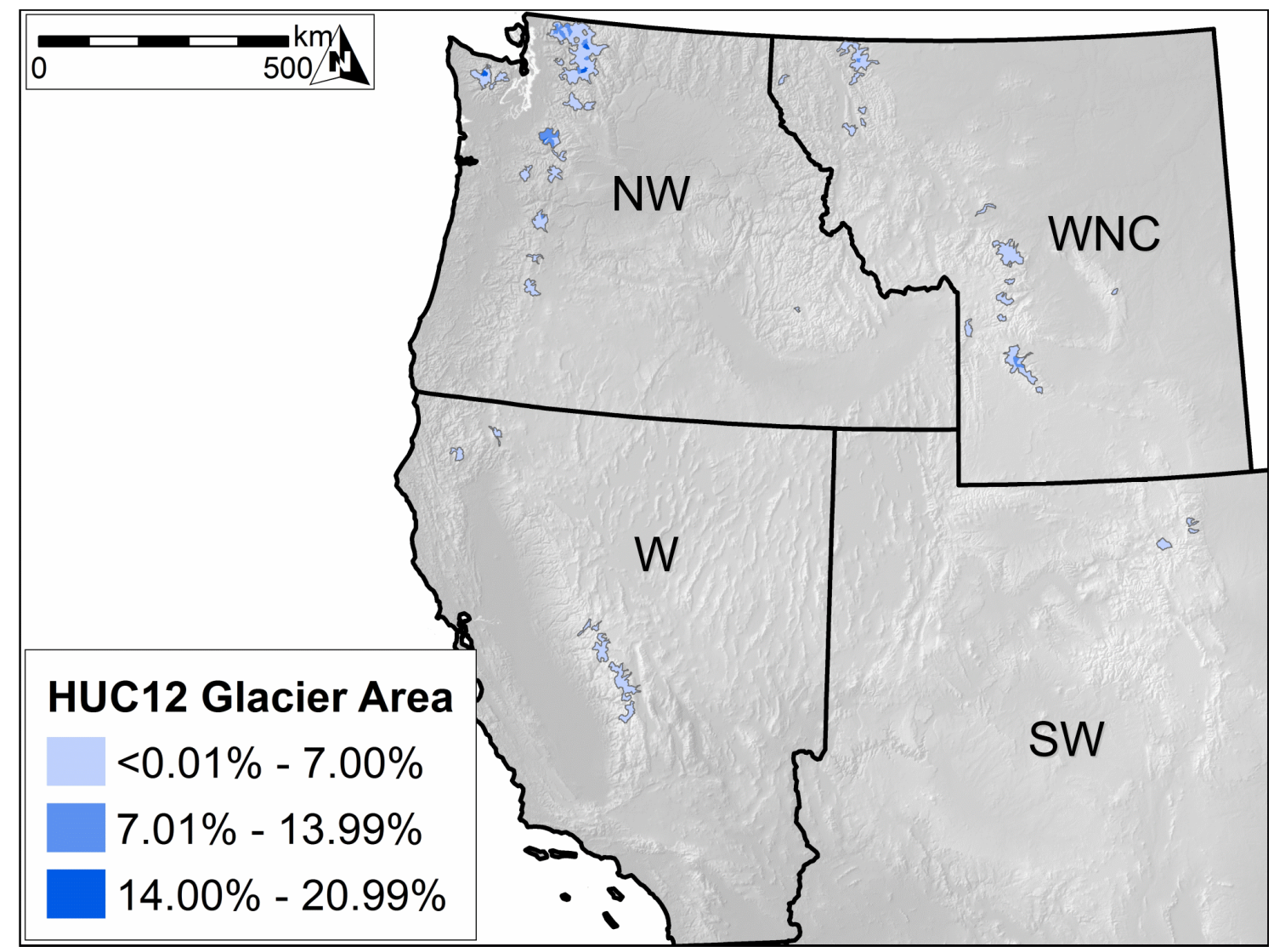

Figure 12: Glacier areas, as a percent of the HUC12 watersheds entirely within the contiguous U.S. that contain them. 


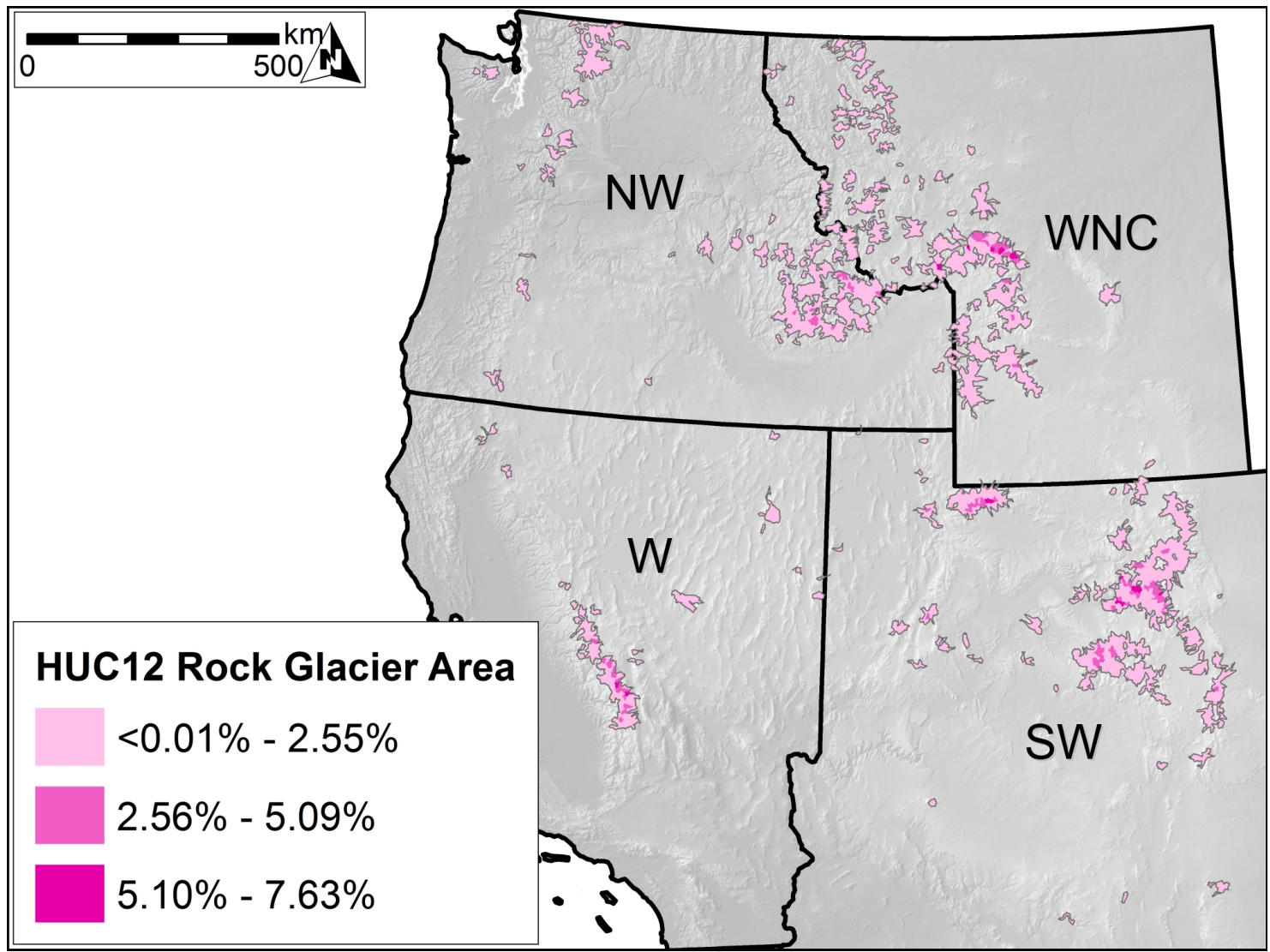

Figure 13: Rock glacier areas, as a percent of the HUC12 watersheds entirely within the contiguous U.S. that contain them. 


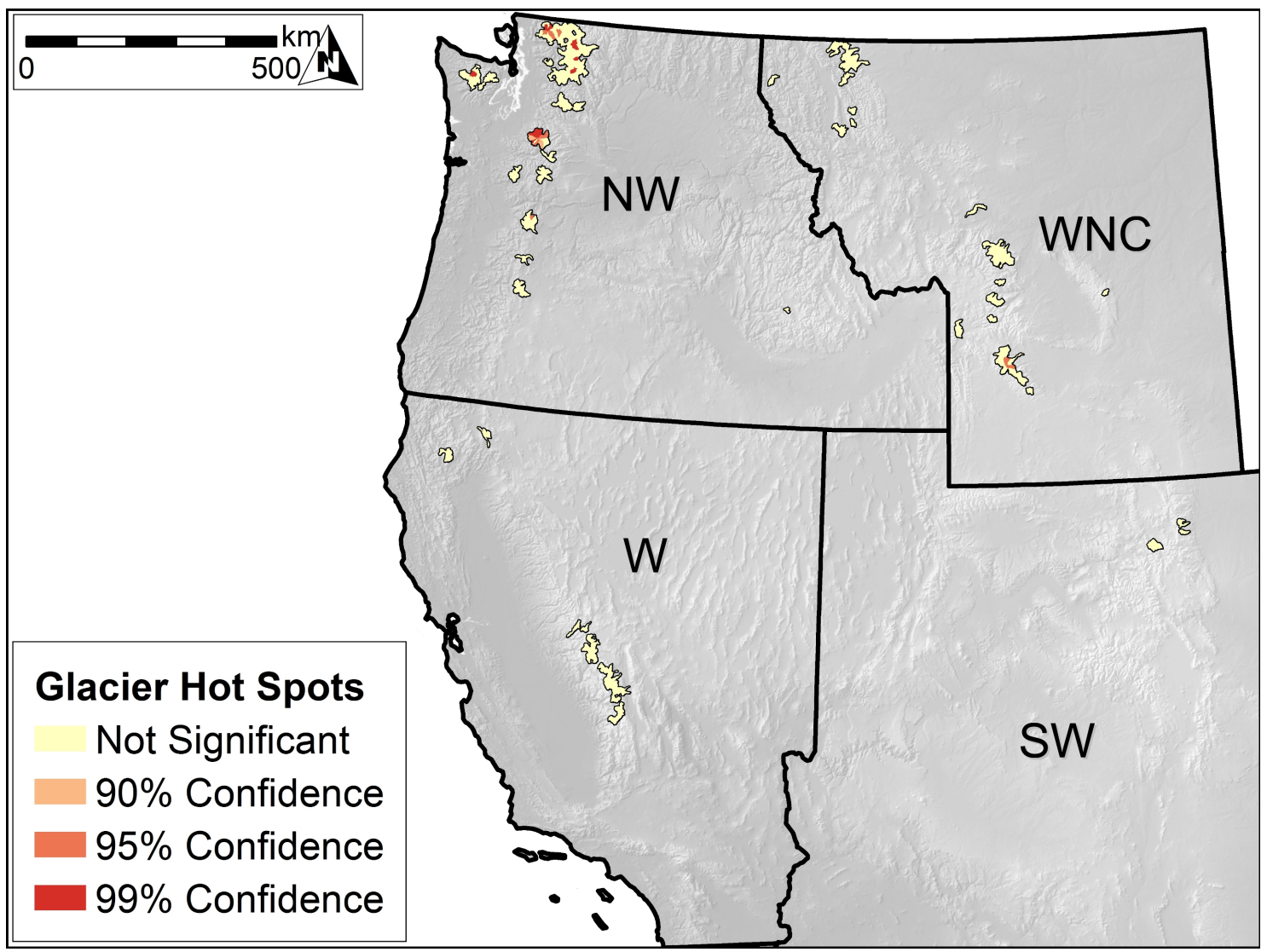

Figure 14: Statistically significant Getis-Ord Gi* hot spots for glacier percent area at the HUC12 watershed level. Moran's I analysis shows glacier percent area is significantly clustered (Moran's Index $=0.33$, z-score $=9.17$ ). No statistically significant cold spots are observed. 


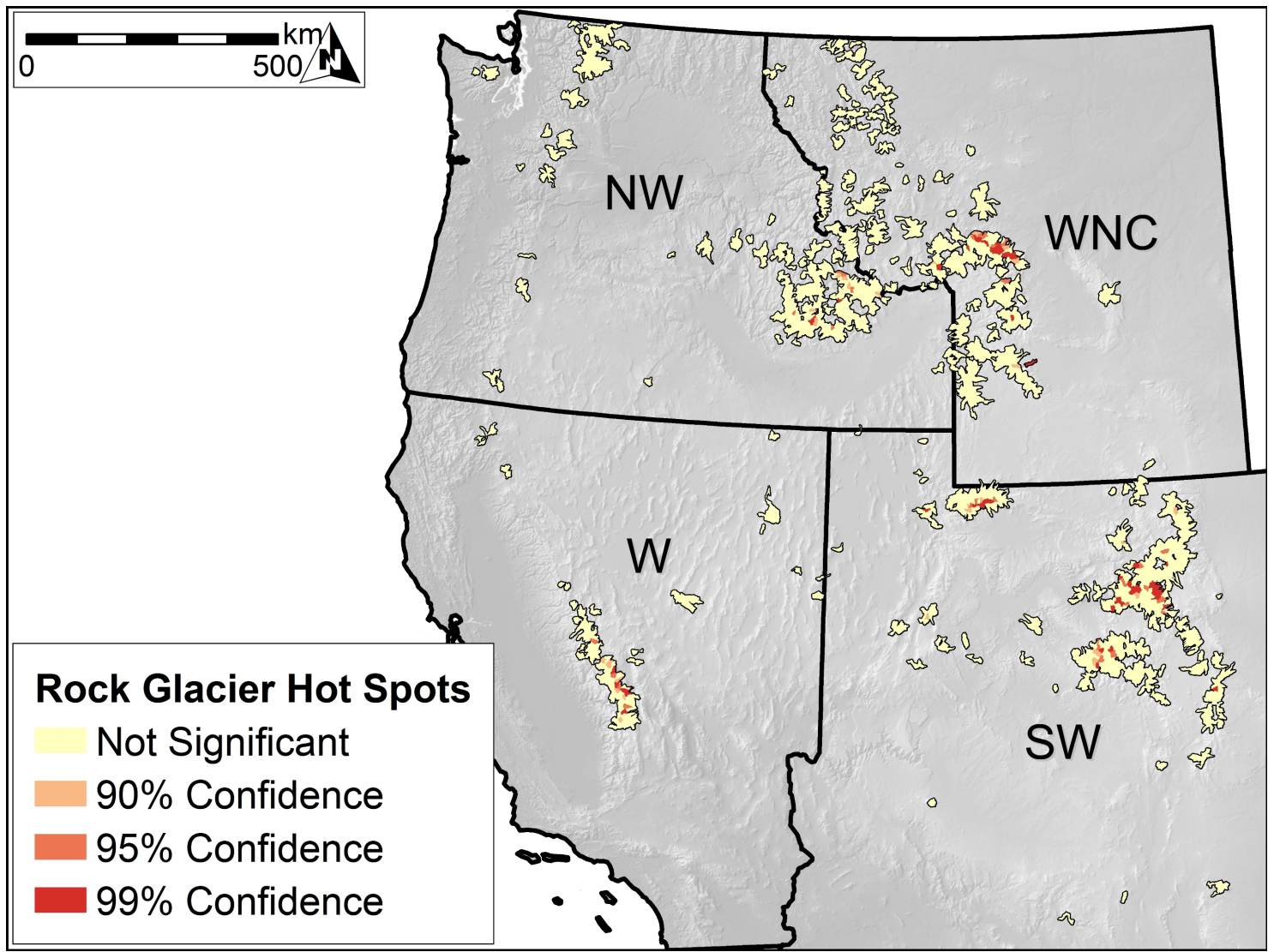

Figure 15: Statistically significant Getis-Ord Gi* hot spots for rock glacier percent area at the HUC12 watershed level. Moran's I analysis shows rock glacier percent area is significantly clustered (Moran's Index $=0.27, z$-score $=22.35$ ). No statistically significant cold spots are observed. 

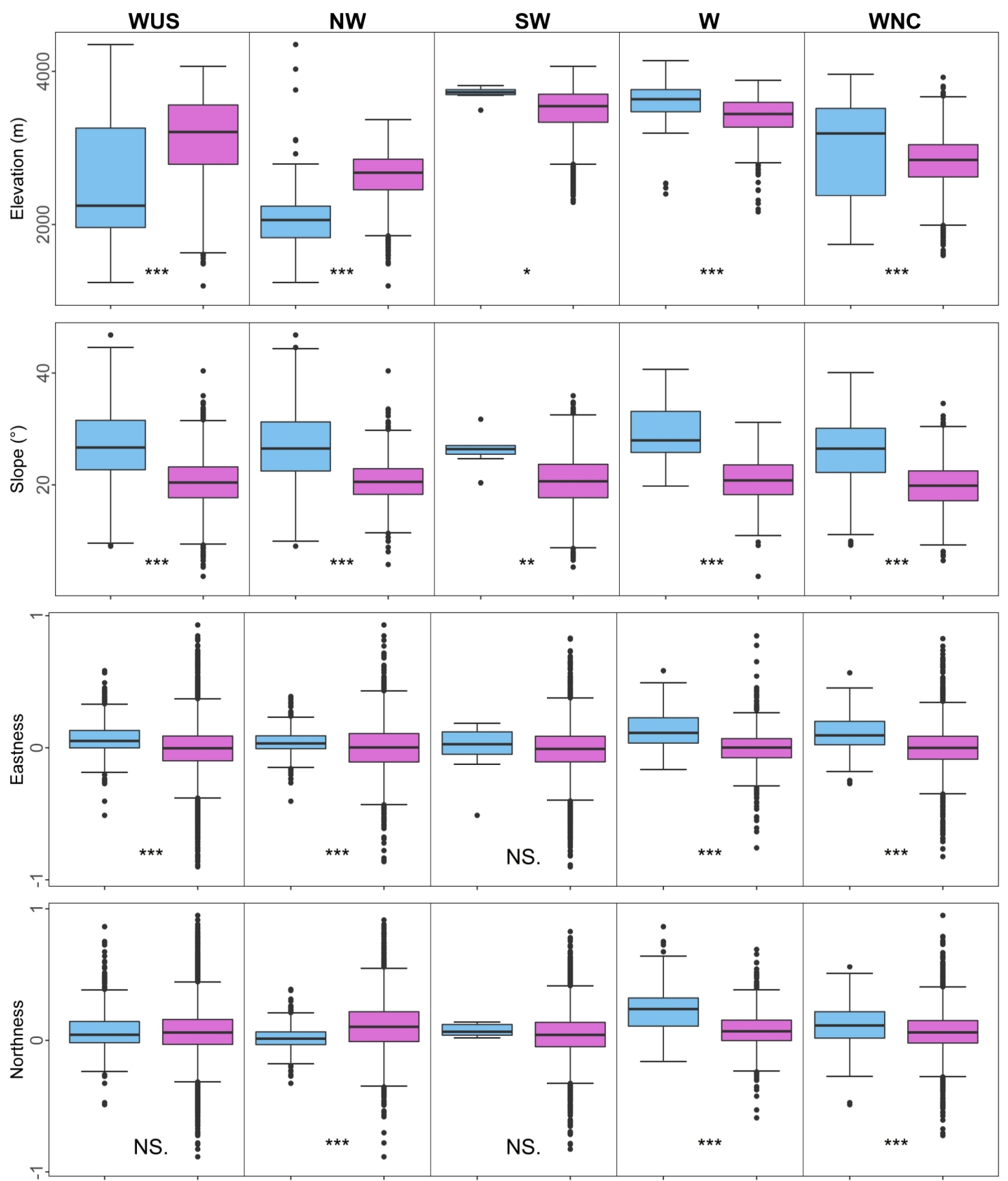

Figure 16: Characteristics of glaciers (blue, $n=853$ ) and rock glaciers (pink, $n=10,343$ ) in the complete data sets (WUS) and by region (NW region, SW region, W region, WNC region). Statistically significant differences (Wilcoxon rank-sum, $\alpha=0.05$ ) are denoted with asterisks ( $p$ $<0.001={ }^{* * *}, p<0.01={ }^{* *}, p<0.05={ }^{*}, p>0.05=N S$ ). 

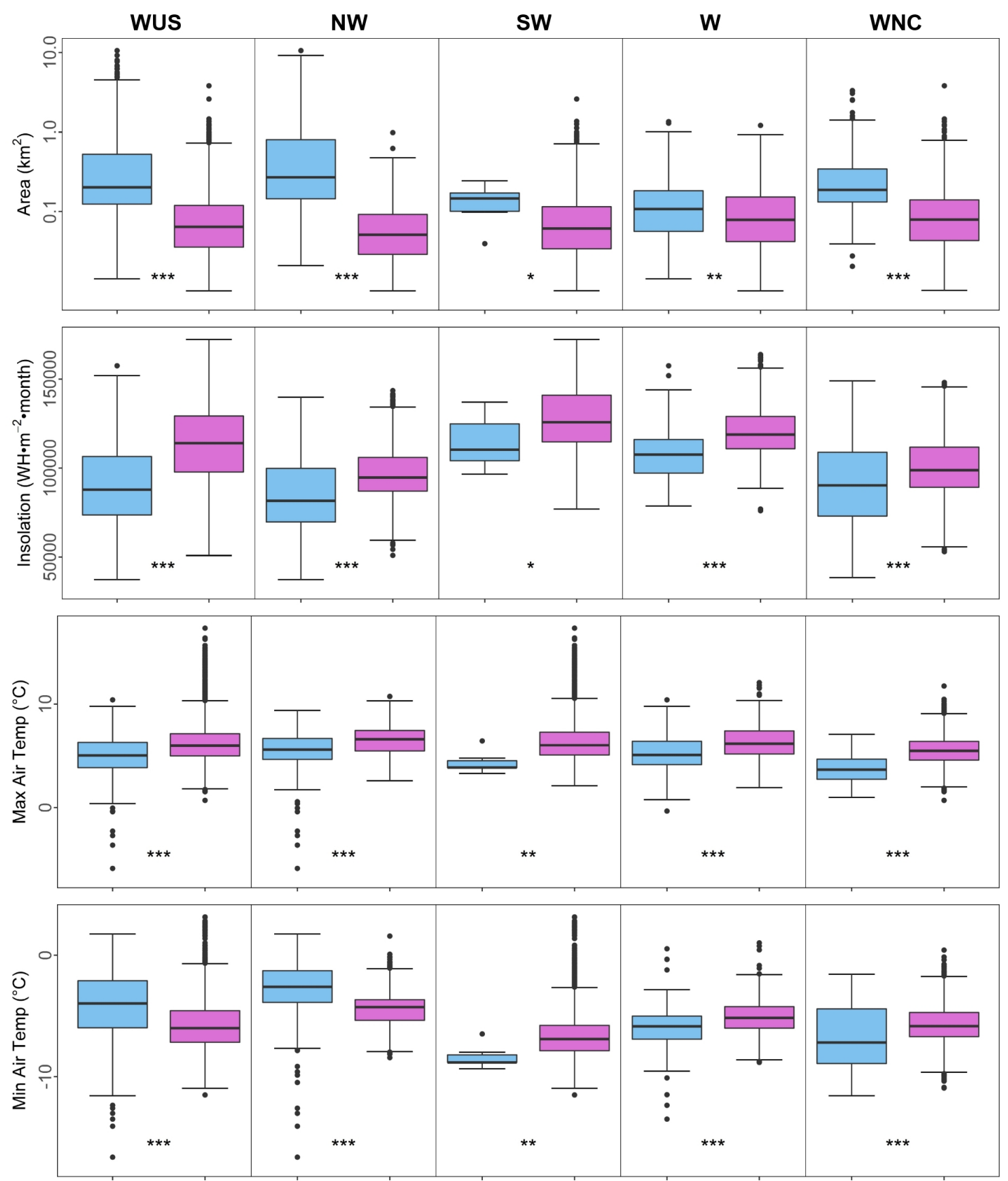

Figure 17: Characteristics of glaciers (blue, $n=853$ ) and rock glaciers (pink, $n=10,343$ ) in the complete data sets (WUS) and by region (NW region, SW region, W region, WNC region). Statistically significant differences (Wilcoxon rank-sum, $\alpha=0.05$ ) are denoted with asterisks ( $p$ $<0.001={ }^{* * *}, p<0.01={ }^{* *}, p<0.05={ }^{*}, p>0.05=N S$ ). 

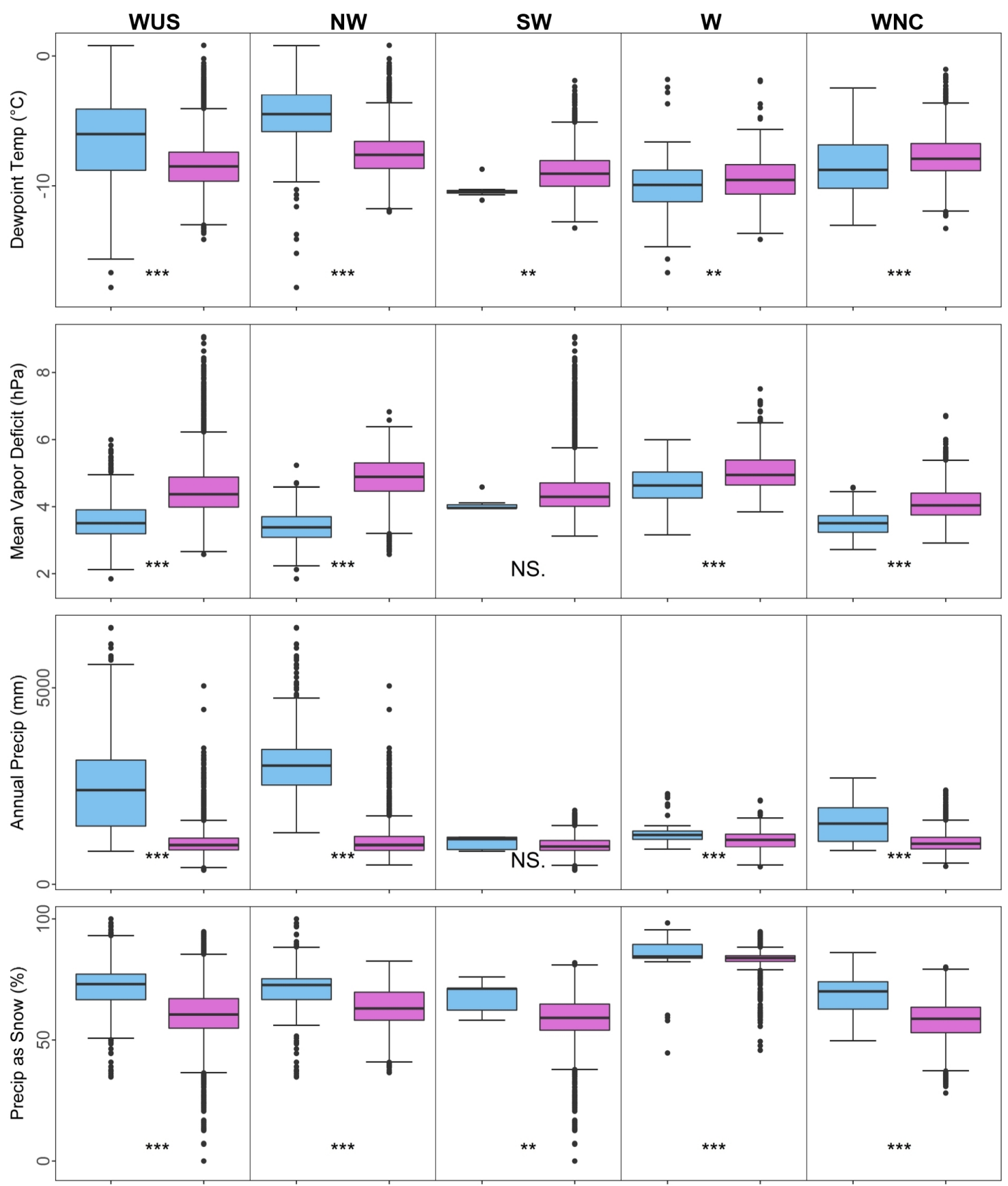

Figure 18: Characteristics of glaciers (blue, $n=853$ ) and rock glaciers (pink, $n=10,343$ ) in the complete data sets (WUS) and by region (NW region, SW region, W region, WNC region). Statistically significant differences (Wilcoxon rank-sum, $\alpha=0.05$ ) are denoted with asterisks ( $p$ $<0.001={ }^{* * *}, p<0.01={ }^{* *}, p<0.05={ }^{*}, p>0.05=N S$ ). 


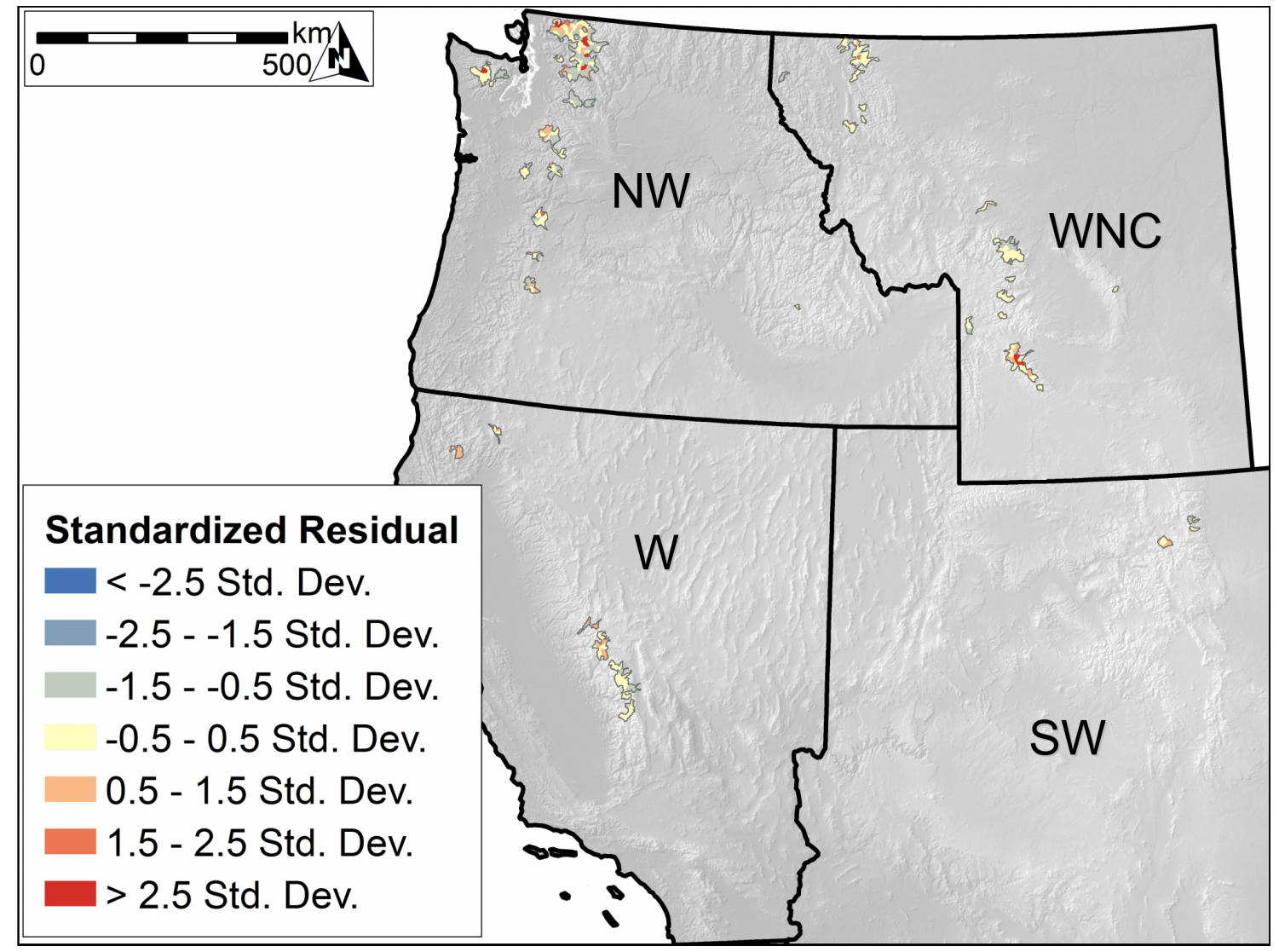

Figure 19: Standardized residuals for the Chapter 3 glacier OLS model. 


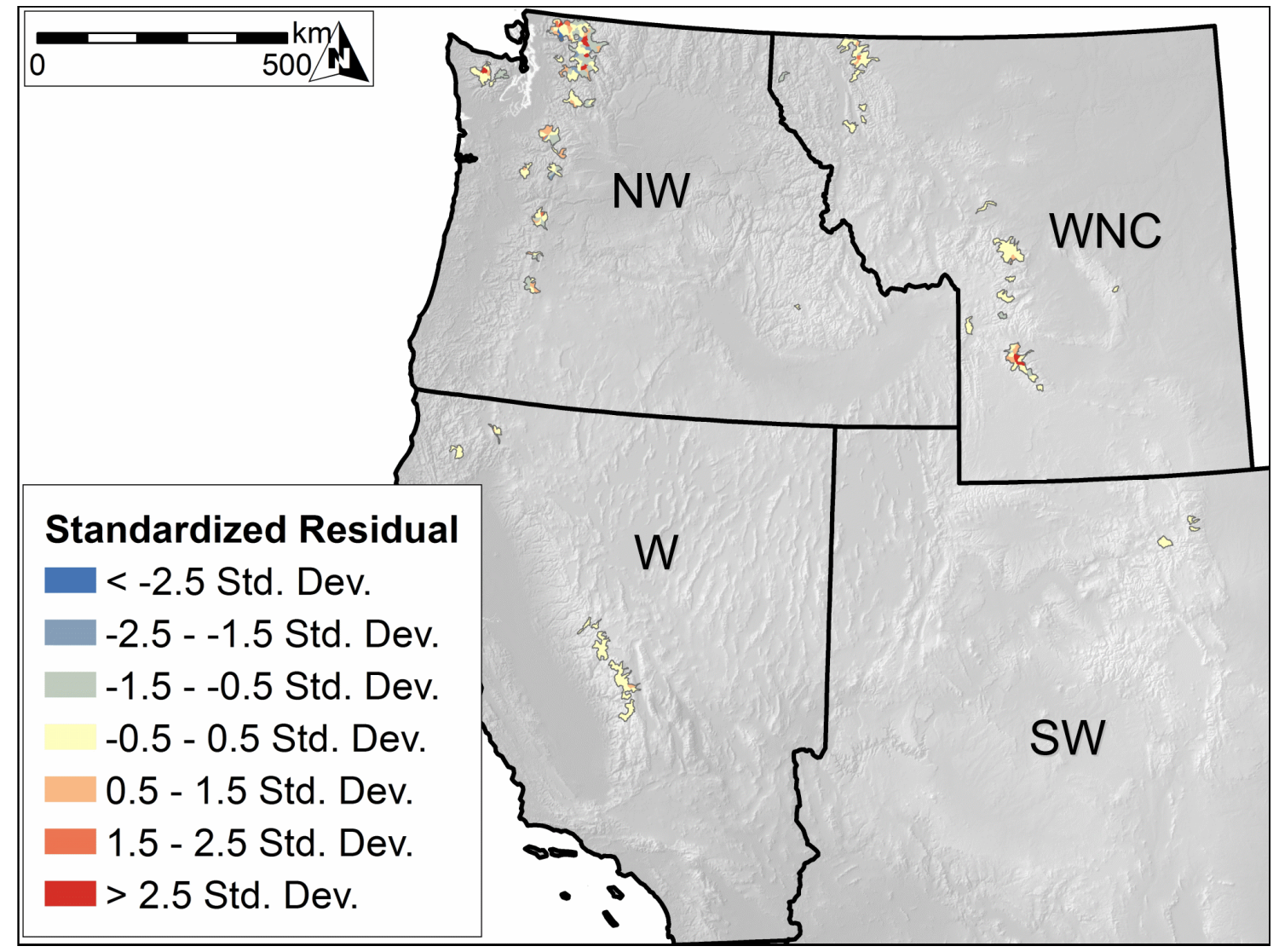

Figure 20: Standardized residuals for the Chapter 3 glacier final GWR model. 


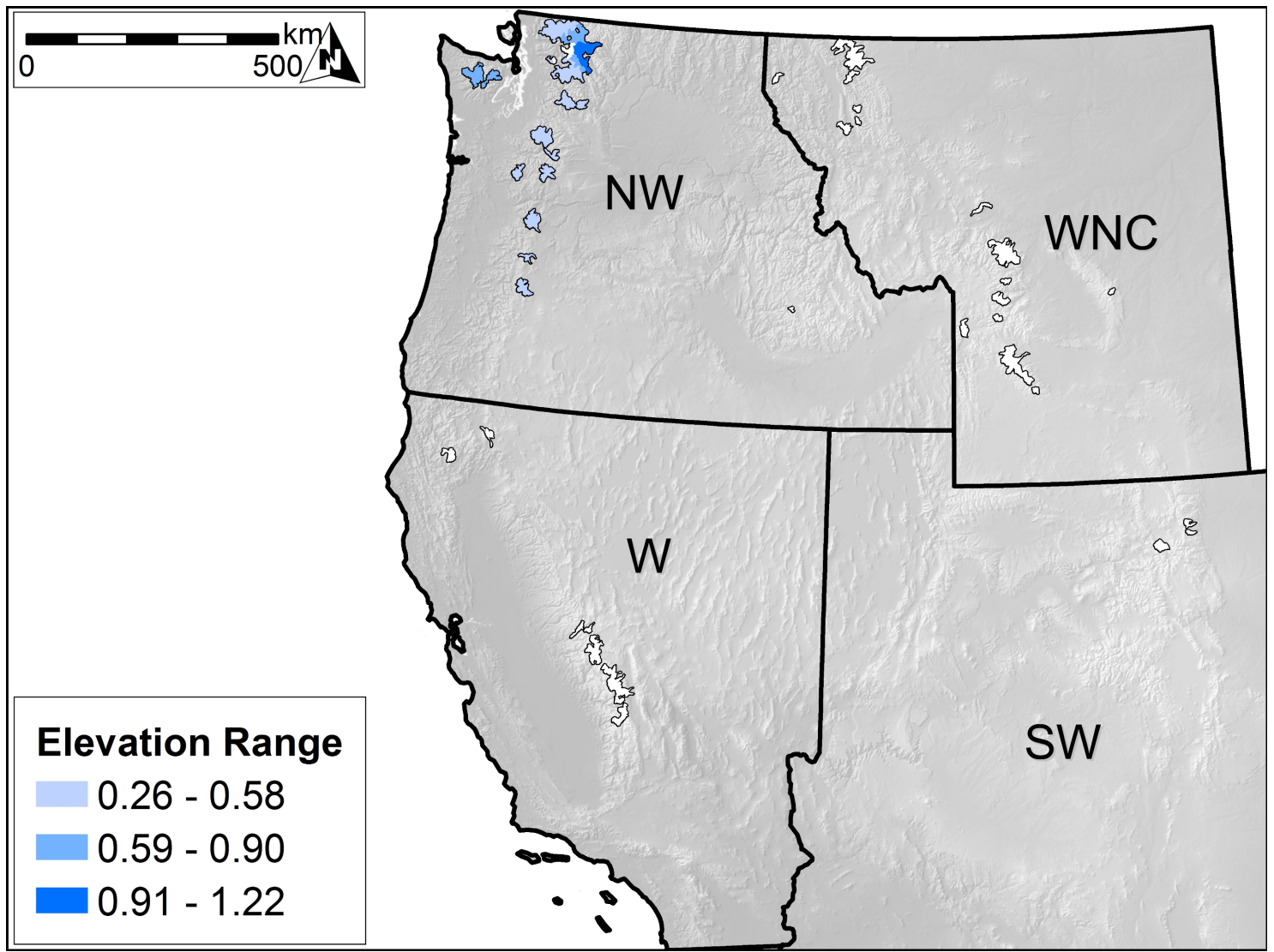

Figure 21: The Chapter 3 glacier final GWR model does not allow the coefficients for elevation range to vary in sign. While the coefficients are positive in all 267 HUC12 watersheds considered, these coefficients cannot universally be confidently shown to significantly differ from zero. However, the coefficient can confidently be shown to significantly differ from zero in the 133 mapped here. Coefficients have been multiplied by 1000 for clarity. 


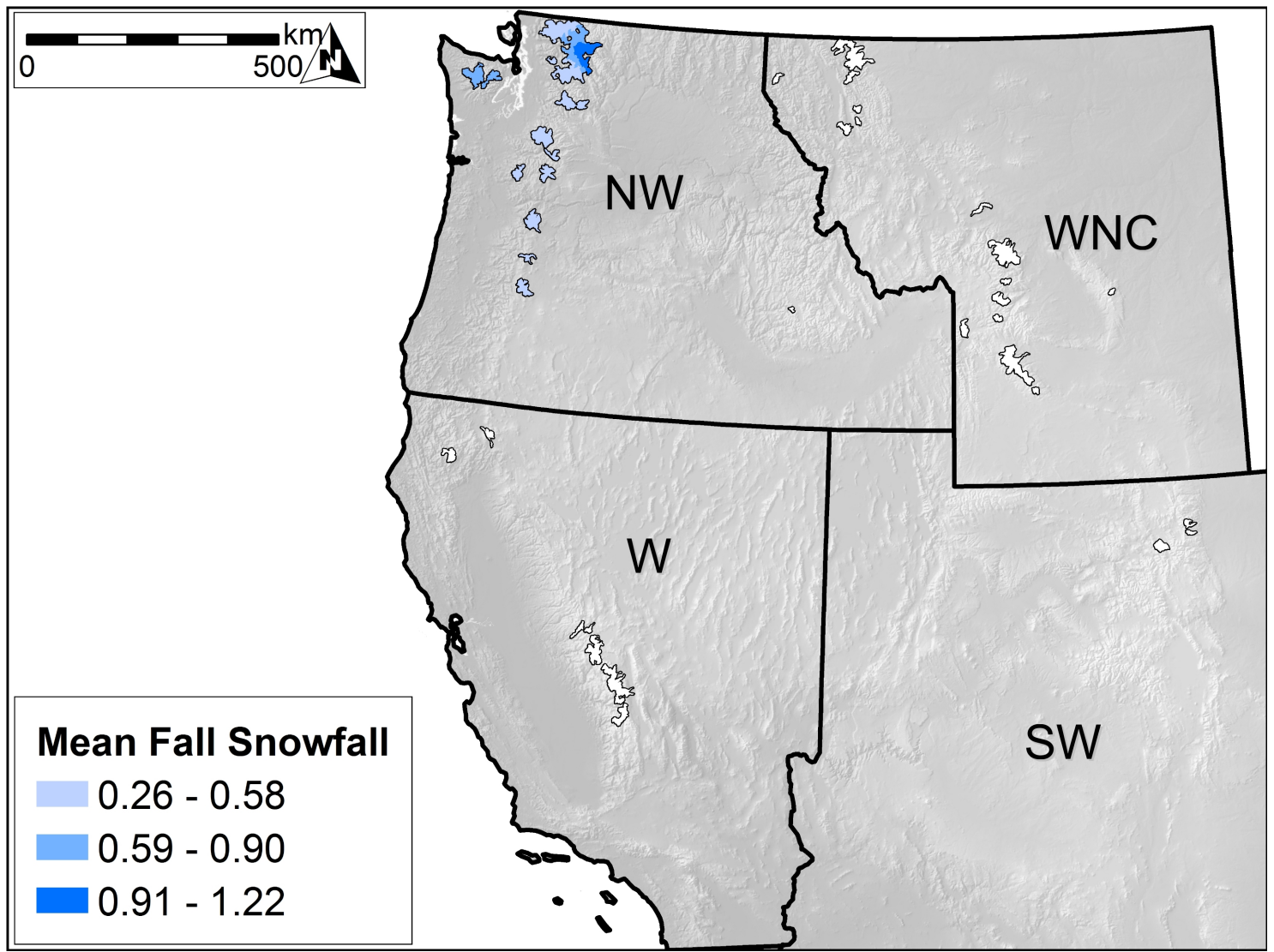

Figure 22: The Chapter 3 glacier final GWR model does not allow the coefficients for mean fall snowfall to vary in sign. While the coefficients are positive in all 267 HUC12 watersheds considered, these coefficients cannot universally be confidently shown to significantly differ from zero. However, the coefficient can confidently be shown to significantly differ from zero in the 138 mapped here. Coefficients have been multiplied by 1000 for clarity. 


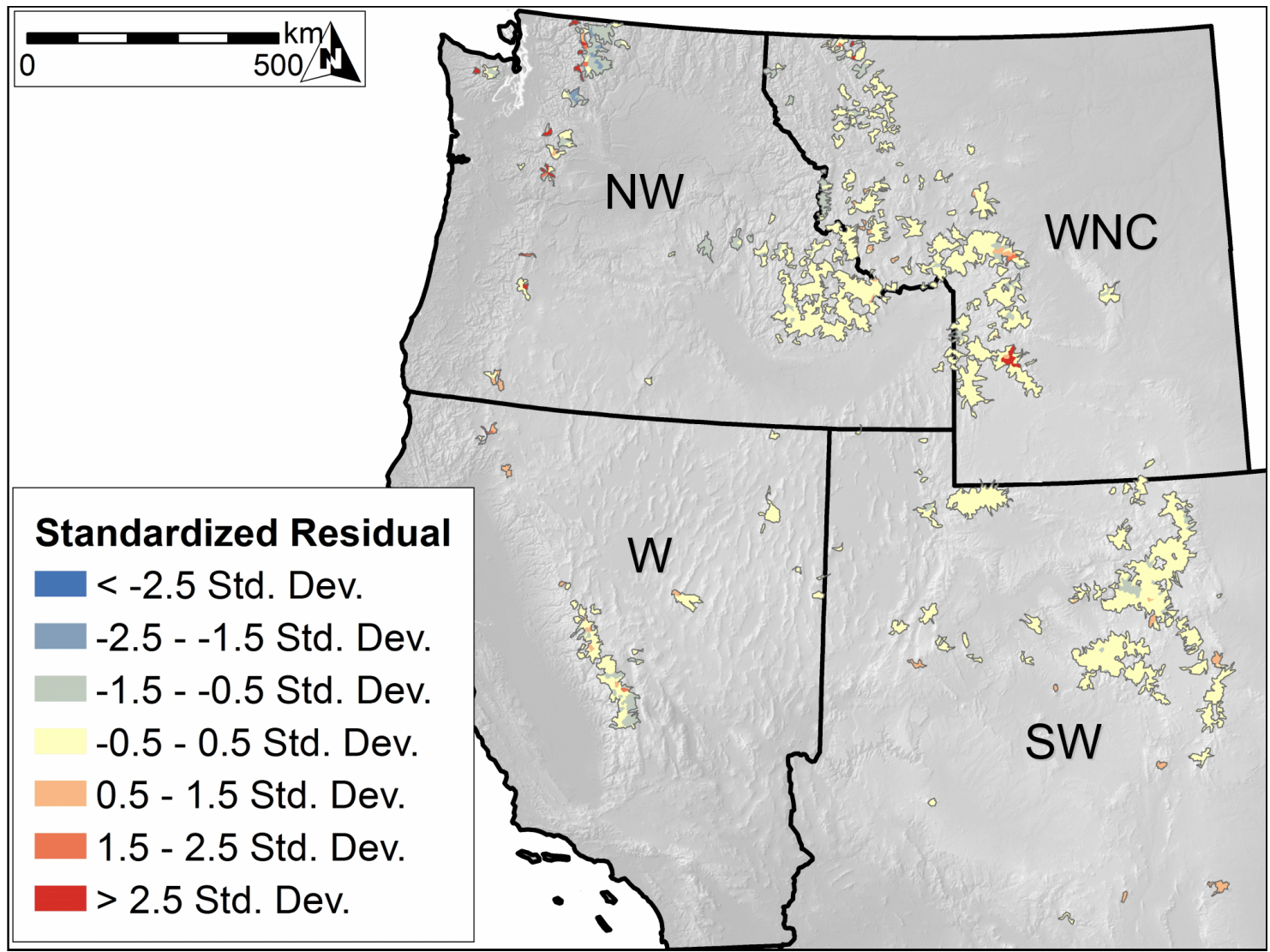

Figure 23: Standardized residuals for Chapter 3 rock glacier OLS model. 


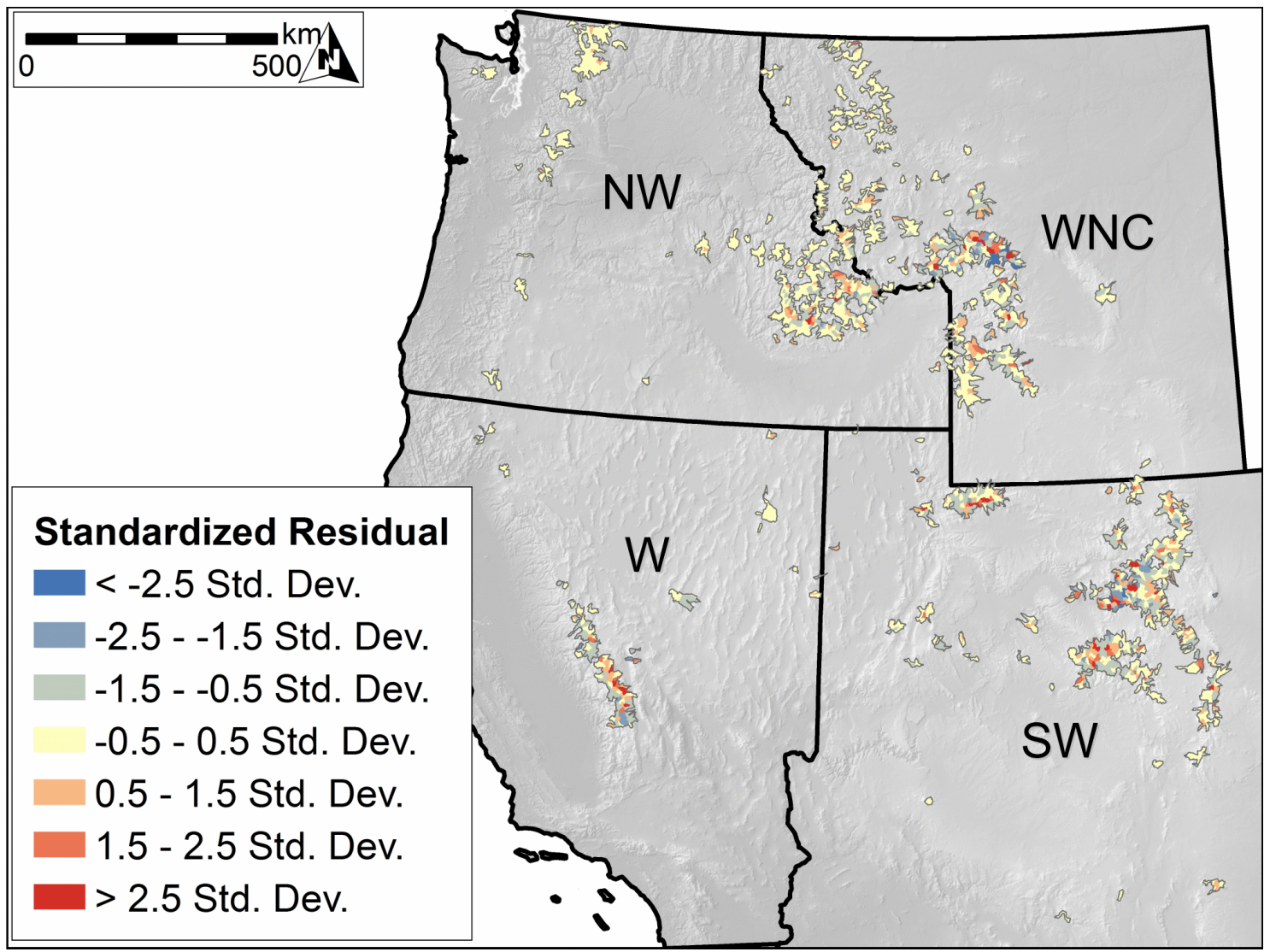

Figure 24: Standardized residuals for the Chapter 3 rock glacier GWR model. 


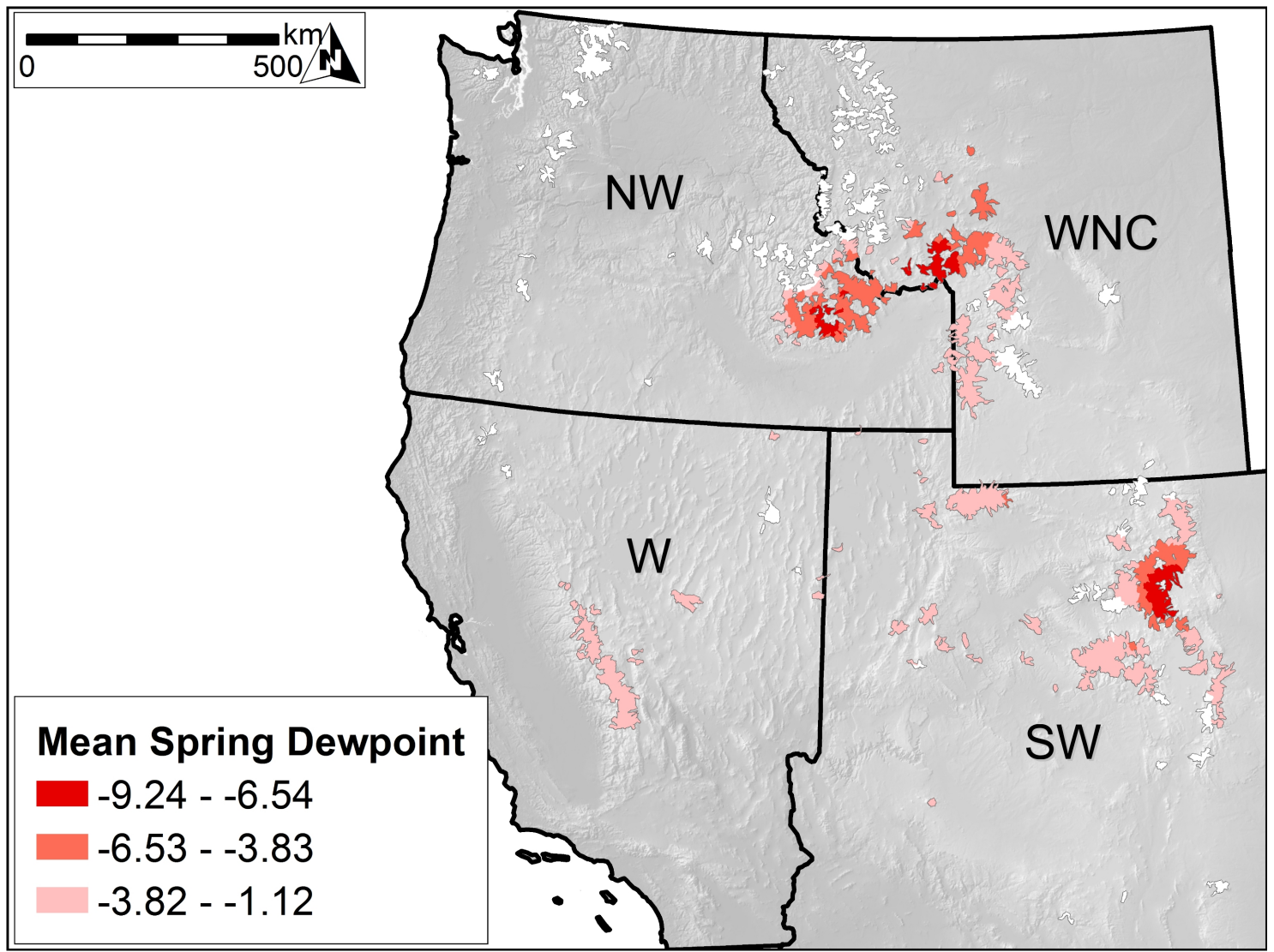

Figure 25: The Chapter 3 rock glacier GWR model allows the coefficients for mean spring dewpoint temperature to vary in sign. Of the 14 HUC12 watersheds where the coefficient is positive, the coefficient can confidently be shown to significantly differ from zero in none. Of the 1509 HUC12 watersheds where the coefficient is negative, the coefficient can confidently be shown to significantly differ from zero in the 1033 mapped here. Coefficients have been multiplied by 1000 for clarity. 


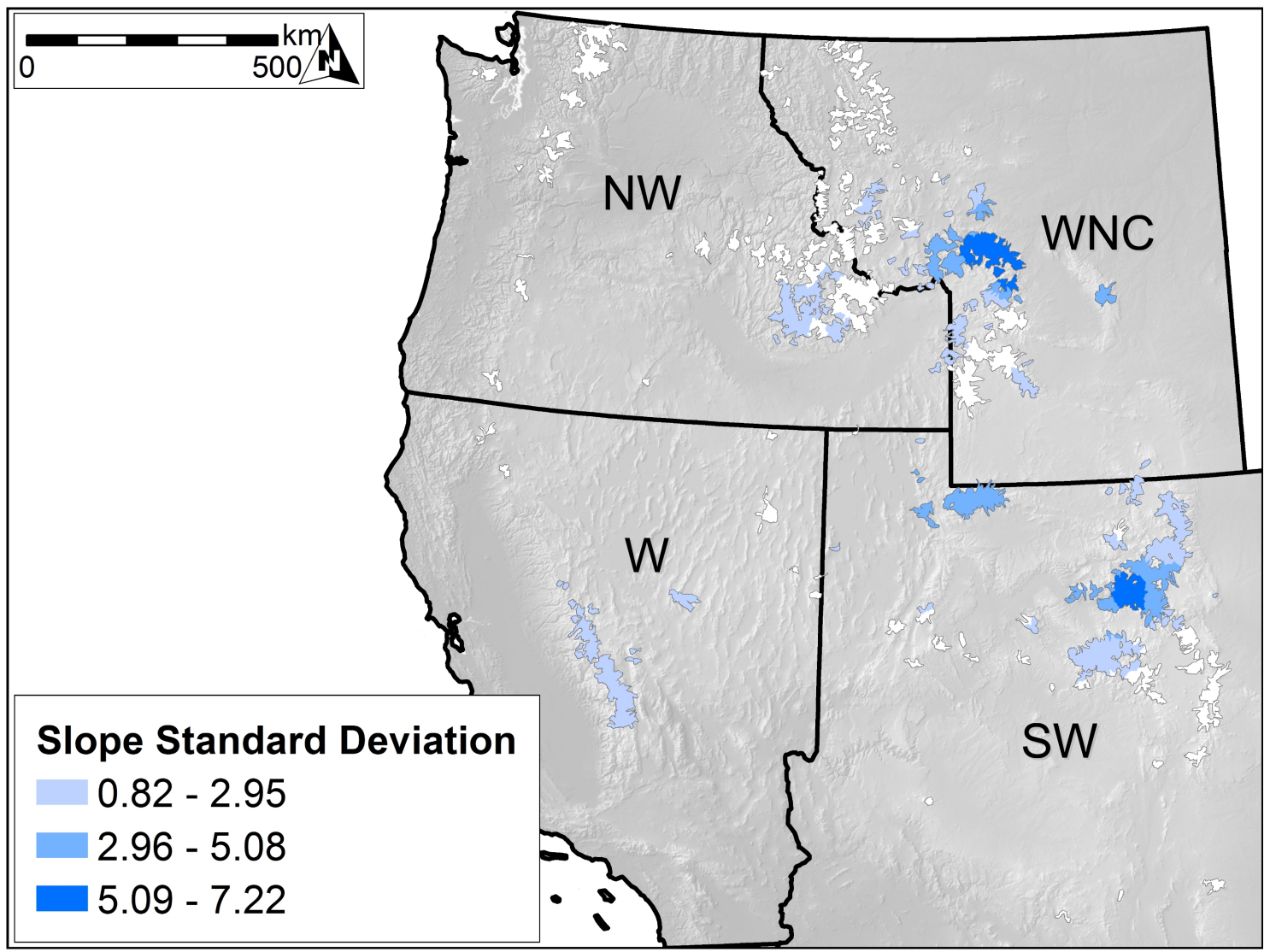

Figure 26: The Chapter 3 rock glacier GWR model allows the coefficients for slope standard deviation to vary in sign. Of the 1306 HUC12 watersheds where the coefficient is positive, the coefficient can confidently be shown to significantly differ from zero in the 845 mapped here. Of the 207 HUC12 watersheds where the coefficient is negative, the coefficient can confidently be shown to significantly differ from zero in none. Coefficients have been multiplied by 1000 for clarity. . 


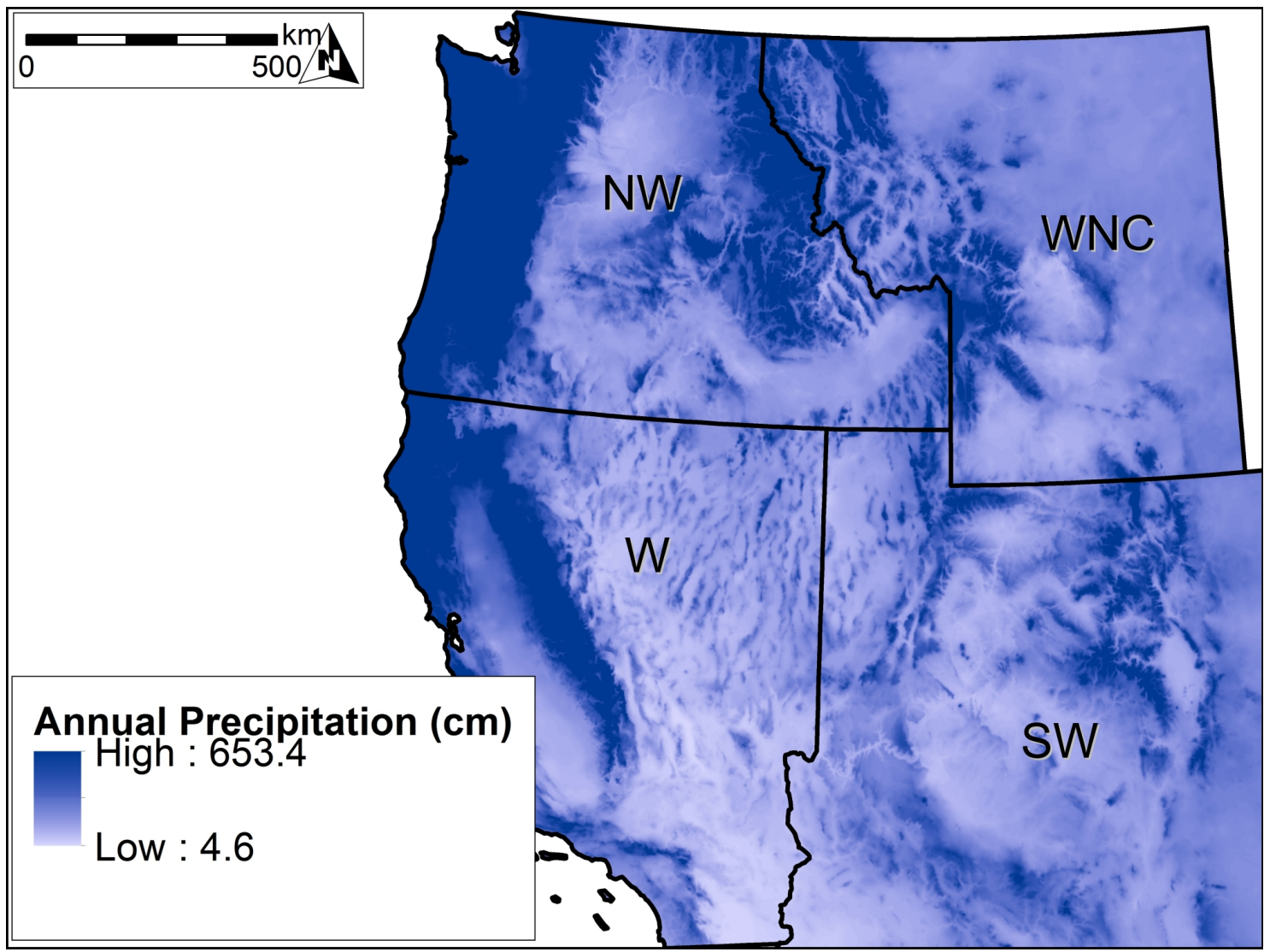

Figure 27: Mean annual precipitation taken from PRISM 1981 - 2010 normals. 


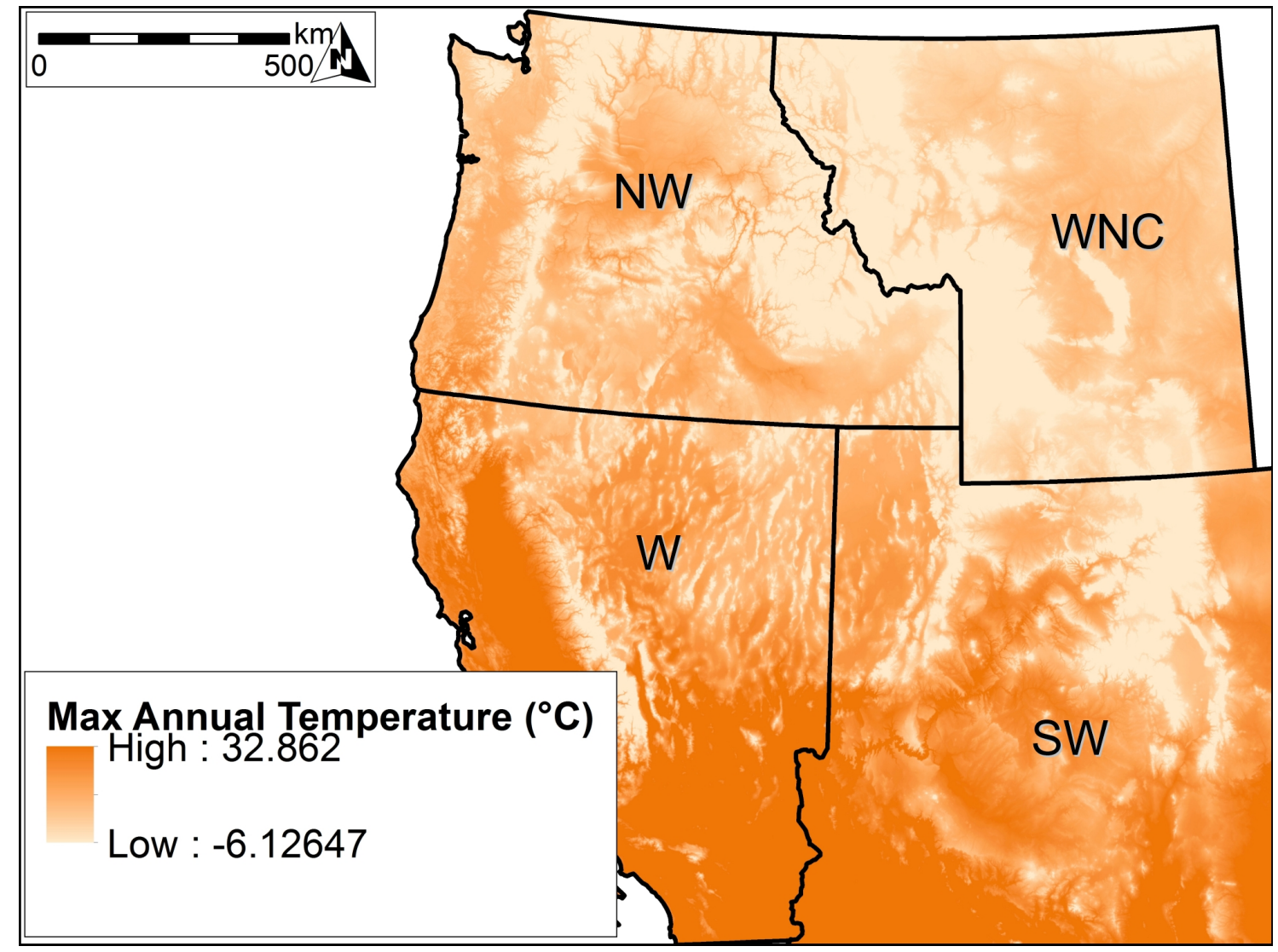

Figure 28: Mean annual air temperature taken from PRISM 1981 - 2010 normals. 


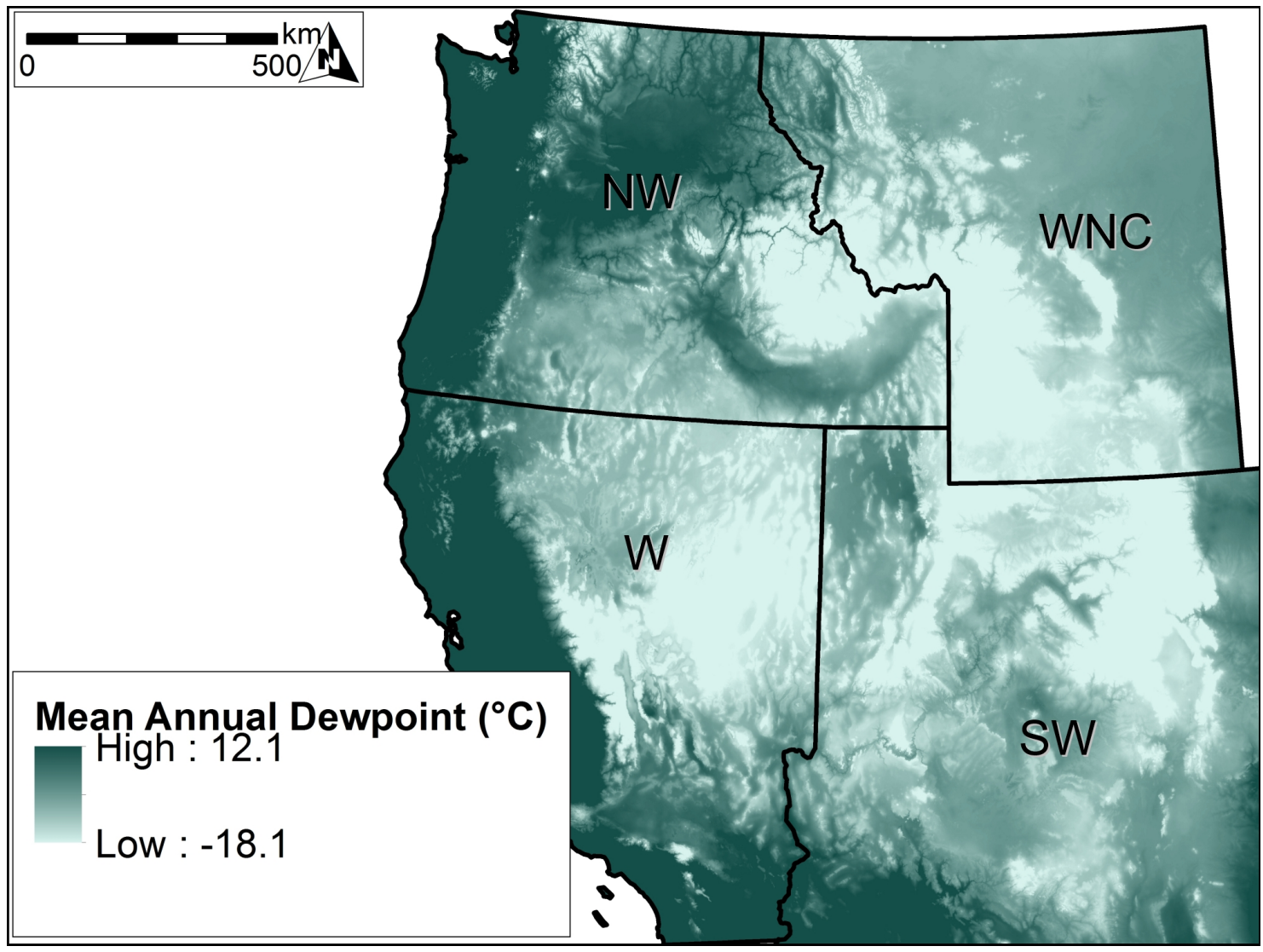

Figure 29: Mean annual dewpoint taken from PRISM 1981 - 2010 normals. 
Chapter 4 Figures 


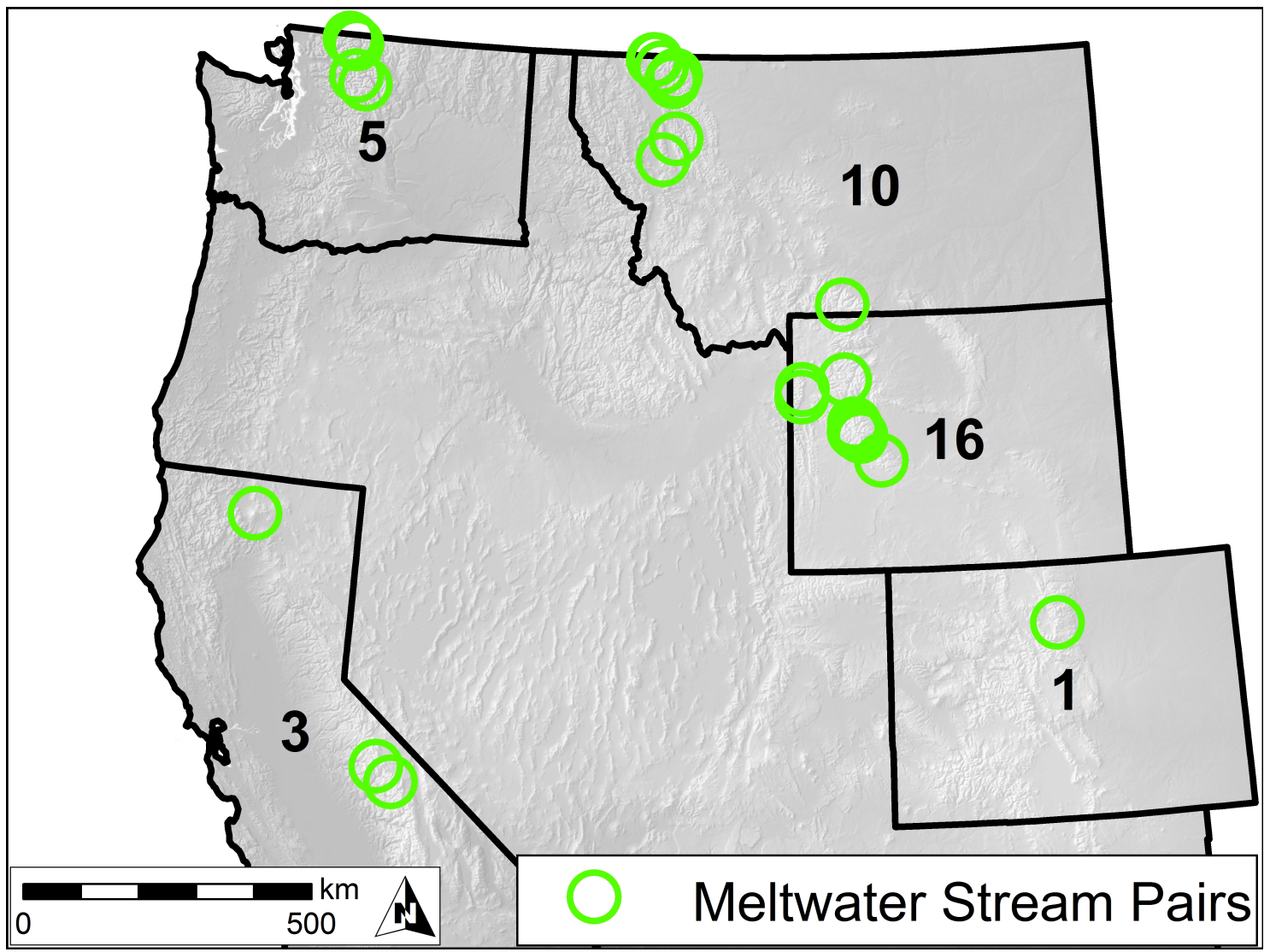

Figure 30: Map of 35 glacier and rock glacier riparian vegetation analysis meltwater stream pairs, with counts for each state. The primary constraints on finding meltwater stream pairs stem from the relatively small and highly clustered glacier distribution as compared to rock glaciers. Secondary constraints stem from the need to select only "true" glaciers and rock glaciers, not glaciers that flow into large ice-cored terminal moraines or transitional features such as rock glaciers with small glacierettes in their accumulation zones. Meltwater stream selected have only glaciers or rock glaciers in their contributing drainage areas, not a combination of both cryospheric feature types. 


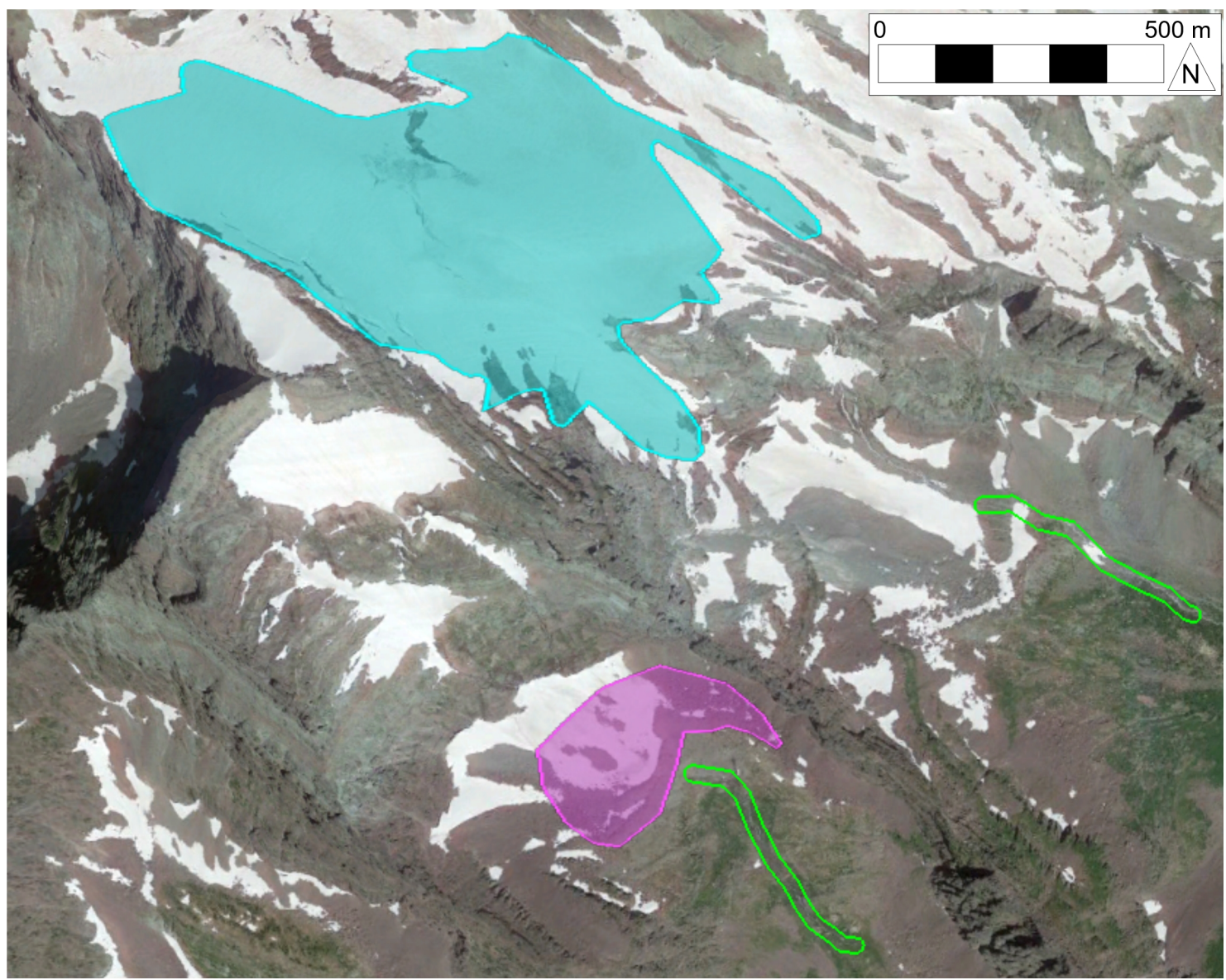

Figure 31: Representative plan-view DigitalGlobe QuickBird satellite image (July 25, 2013) of a glacier and rock glacier meltwater stream pair. The glacier at the top of the frame is outlined in blue, the rock glacier at the bottom of the frame is outlined in pink and the meltwater riparian buffers are outlined in green. 


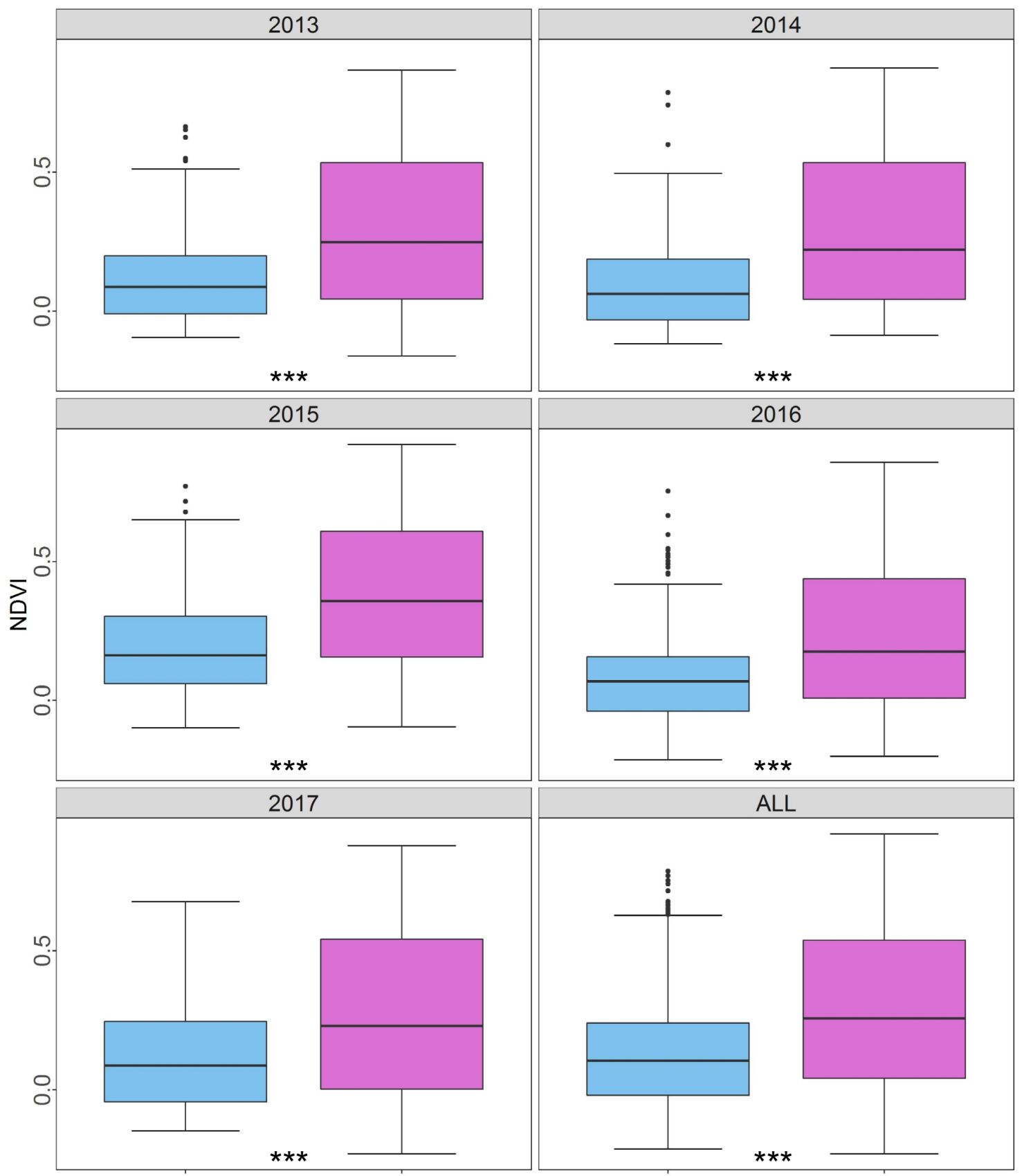

Figure 32: Box plots illustrating significant differences between meltwater stream riparian vegetation density by growing season. For all plots, $n=35$ for each meltwater stream type. In all growing seasons evaluated, rock glacier meltwater stream riparian vegetation density was significantly greater than glacier meltwater stream riparian vegetation density. The largest difference was observed during the 2015 growing season (glacier mean NDVI $=0.192$, rock glacier mean $N D V I=0.377$, difference $=0.185)$, while the smallest difference was observed during the 2016 growing season (glacier mean NDVI $=0.102$, rock glacier mean $N D V I=0.240$, difference $=0.138$ ). Statistical significance notation: $p$-values $>0.1=n$.s., $p$-values $<0.1={ }^{*}, p$ values $<0.05={ }^{* *}, p$-value $<0.01={ }^{* * *}$. 


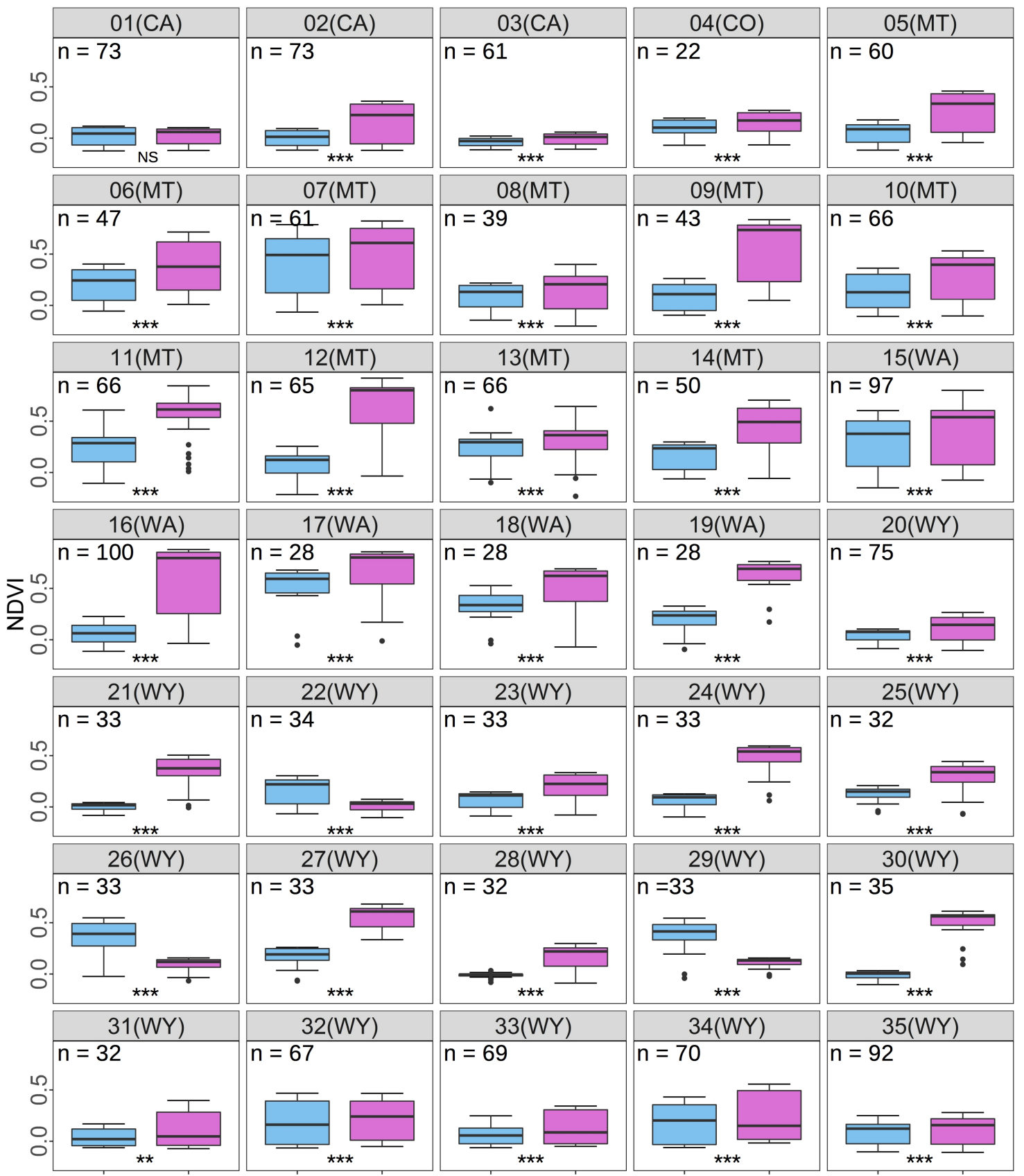

Figure 33: Box plots illustrating significant differences between meltwater stream riparian vegetation density by growing season. At all but four stream pairs, rock glacier meltwater stream riparian vegetation density was significantly greater than glacier meltwater stream riparian vegetation density. At stream pair 01(CA), rock glacier meltwater stream riparian vegetation density (mean $N D V I=0.023$ ) was greater than glacier meltwater stream riparian vegetation density (mean NDVI $=0.021$ ), but the difference was not statistically significant. At three stream pairs (22(WY), 26(WY), 29(WY)), glacier meltwater stream riparian vegetation density was significantly greater than rock glacier meltwater stream riparian vegetation density. Statistical significance notation: $p$-values $>0.1=n$.s., $p$-values $<0.1={ }^{*}$, $p$-values $<0.05={ }^{* *}$, p-value $<0.01={ }^{* * *}$. 


\section{Literature Cited}

- Angillieri M (2010) Application of frequency ratio and logistic regression to active rock glacier occurrence in the Andes of San Juan, Argentina. Geomorphology, 114:396-405

- Aoyama M (2005) Rock glaciers in the northern Japanese Alps: Paleoenvironmental implications since the Late Glacial. Journal of Quaternary Science, 20(5):471-484

- Arendt A, Bliss A, Bolch T, Cogley J, Gardner A, Hagen J, ... and Zheltyhina N (2015) Randolph Glacier Inventory: A data set of global glacier outlines, version 5.0. GLIMS Technical Report: National Snow and Ice Data Center, Boulder, CO, July 2015:1-63

- Bajewsky I and Gardner J (2013) Discharge and sediment-load characteristics of the Hilda Rock-Glacier stream, Canadian Rocky Mountains, Alberta. Physical Geography, 10(4):295-306

- Barnett T, Pierce D, Hidalgo H, Bonfils C, Santer B, Das T, ... and Dettinger M (2008) Human-induced changes in the hydrology of the western United States. Science, 319:1080-1083

- Baroni C, Carton A, Seppi R and Harris C (2004) Distribution and behaviour of rock glaciers in the Adamello-Presanella Massif (Italian alps). Permafrost and Periglacial Processes, 15(3), 243-259.

- Basagic H and Fountain A (2011) Quantifying 20th century glacier change in the Slerra Nevada, California. Arctic, Antarctic, and Alpine Research, 43(3):317-330

- Bassler C, Hothorn T, Brandl R and Muller J (2013) Insects overshoot the expected upslope shift caused by climate warming. Public Library of Science One, 8(6):1-6 
- Beever E, Ray C, Wilkening J, Brussard P and Mote P (2011) Contemporary climate change alters the pace and drivers of extinction. Global Change Biology, 17:2054-207

- Beger M, Grantham H, Pressey R, Wilson K, Peterson E, Dorfman D, ... and Possingham $\mathrm{H}$ (2010) Conservation planning for connectivity across marine, freshwater, and terrestrial realms. Biological Conservation, 143:565-575

- Bell D, Bradford J and Laurenroth W (2014) Mountain landscapes offer few opportunities for high-elevation tree species migration. Global Change Biology, 20:1441-1451

- Bennett A, Nimmo D and Radford J (2014) Riparian vegetation has disproportionate benefits for landscape-scale conservation of woodland birds in highly modified environments. Journal of Applied Ecology, 51:514523

- Berthling I (2011) Beyond confusion: Rock glaciers as cryo-conditioned landforms. Geomorphology, 131:98-106

- Berthling I (2011b) Beyond confusion: Rock glaciers as cryo-conditioned landforms. Geomorphology, 131:98-106

- Berthling I and Etzelmuller B (2011a) The concept of cryo-conditioning in landscape evolution. Quaternary Research, 75:378-384

- Bertoldi W, Zanoni L and Tubino M (2010) Assessment of morphological changes induced by flow and flood pulses in a gravel bed braided river: The Tagliamento River (Italy). Geomorphology, 114(3):348-360

- Bodin X, Krysiecki J, Schoeneich P, Le Roux O, Lorier L, Echelard T, ... and Walpersdorf A (2017) The 2006 collapse of the Bérard Rock Glacier (Southern French Alps). Permafrost and Periglacial Processes, 28: 209223 
- Bodin X, Rojas F and Brenning A (2010) Status and evolution of the cryosphere in the Andes of Santiago (Chile, 33.5 degrees $S$ ). Geomorphology, 118(3-4):453-464

- Bodin X, Thibert E, Fabre D, Ribolini A, Schoeneich P, Francou B, Reynaud B and Fort M (2009) Two decades of responses (1986-2006) to climate by the Laurichard rock glacier, French Alps. Permafrost and Periglacial Processes, 20(4):331-344

- Bolch T and Gorbunov A (2014) Characteristics and origin of rock glaciers in Northern Tian Shan (Kazakhstan/Kyrgystan). Permafrost and Periglacial Processes, 25: 320-332

- Brenning A (2009) Benchmarking classifiers to optimally integrate terrain analysis and multispectral remote sensing in automatic rock glacier detection. Remote Sensing of Environment, 113:239-247

- Brown I and Rod W (1996) The influence of topography on snowpatch distribution in southern Iceland: A new hypothesis for glacier formation? Geografiska Annaler, 78(4):197-207

- Brown L, Hannah D and Milner A (2003) Alpine stream habitat classification: An alternative alpine approach incorporating the role of dynamic water source contributions. Arctic, Antarctic and Alpine Research, 35(3):312-322

- Brown L, Hannah D and Milner A (2010) Predicting river ecosystem response to glacial meltwater dynamics: A case study of quantitative water sourcing and glaciality index approaches. Aquatic Sciences, 72:325-334

- Brown T, Derting T and Fairbanks K (2008) The effects of stream channelization and restoration on mammal species and habitat in riparian corridors. Journal of the Kentucky Academy of Sciences, 69(1):37-49

- Burger K, Degenhardt J and Giardino J (1999) Engineering geomorphology of rock glaciers. Geomorphology, 31:93-132 
- Bush M, Hanselman J and Gosling W (2010) Nonlinear climate change and Andean feedbacks: An imminent turning point? Global Change Biology, 16:3223-3232

- Caccianiga M, Andreis C, Diolaiuti G, D'Agata C, Mihalcea C and Smiraglia C (2011) Alpine debris-covered glaciers as a habitat for plant life. The Holocene, 21(6):1011-1020

- Caine N (2010) Recent hydrologic change in a Colorado alpine basin: An indicator of permafrost thaw? Annals of Glaciology, 51(56):130-134

- Chang H, Jung I, Steele M and Garnett M (2012) Spatial patterns of March and September streamflow trends in Pacific Northwest streams. Geographical Analysis, 44(3):177-201

- Chavez, P (1988) An improved dark-object subtraction technique for atmospheric scattering correction of multispectral data. Remote Sensing of the Environment, 24(3):459-479

- Cheng WM, Wang N, Zhao SM, Fang Y and Zhao M (2016) Growth of the Sayram Lake and retreat of its water-supplying glaciers in the Tianshan Mountains from 1972 to 2011. Journal of Arid Land, 8(1):13-22

- Clark D, Steig E, Potter N and Gillespie A (1998) Genetic variability of rock glaciers. Geografiska Annaler, 80:175-182

- Clark D, Steig E, Potter N, Fitzpatrick J, Updike A and Clark M (1997) Old ice in rock glaciers may provide long-term climate records. Eos, 77(33):217-222

- Cliff A and Ord K (1971) Evaluating the percentage points of a spatial autocorrelation coefficient. Geographical Analysis, 3(1):51-62

- Cremonese E, Gruber S, Phillips M, Pogliotti P, Boeckli L, Noetzli J, ... and Zischg A (2011) An inventory of permafrost evidence for the European Alps. The Cryosphere, 5:651-657

- Cuffey KM and Paterson WSB (2010) The Physics of Glaciers, 4th edition. New York: Elsevier, 707 pp. 
- Degenhardt J (2009) Development of tongue-shaped and multilobate rock glaciers in alpine environments: Interpretations from ground penetrating radar surveys. Geomorphology, 109:94-107

- Delaloye R, Reynard E and Wenker L (1998) Rock Glaciers, Entremon, Valais, Switzerland. National Snow and Ice Data Center/World Data Center for Glaciology, Digital Media, 1998

- Drolon V., Maisongrande P, Berthier E, Swinnen E and Huss M. (2016). Monitoring of seasonal glacier mass balance over the European Alps using low-resolution optical satellite images. Journal of Glaciology, 62(235):912-927

- Duguay M, Edmunds A, Arenson L and Wainstein P (2015) Quantifying the significance of the hydrological contribution of a rock glacier - A review. GEOQuebec 2015: 68th Canadian Geotechnical Conference, 7th Canadian Permafrost Conference (Conference Paper)

- Dyurgerov M and Meier M (2000) Twentieth century climate change: Evidence from small glaciers. PNAS, 97(4):1406-1411

- Elsen P and Tingley M (2015) Global mountain topography and the fate of montane species under climate change. Nature Climate Change, 5:772776

- ESRI (2017). ArcGIS Desktop: Release 104. Redlands, CA:

Environmental Systems Research Institute

- Evans I (2006) Local aspect asymmetry of mountain glaciation: A global survey of consistency of favoured directions for glacier numbers and altitudes. Geomorphology, 73(1):166-184

- Falaschi D, Castro M, Masiokas M, Tadono T and Ahumada A (2014) Rock glacier inventory of the Valles Calchaquies Region ( $\left.\sim 25^{\circ} \mathrm{S}\right)$, Salta, Argentina, derived from ALOS data. Permafrost and Periglacial Processes, 25:69-75 
- Falaschi D, Tadono T and Masiokas M (2015) Rock Glaciers in the Patagonian Andes: An inventory for the Monte San Lorenzo (Cerro Cochrane) Massif, $47^{\circ}$ S. Geografiska Annaler: Series A, Physical Geography, 97(4):769-777

- Feeley K, Silman M, Bush M, Farfan W, Cabrera KG, Malhi Y, ... and Saatachi S (2011) Upslope migration of Andean trees. Journal of Biogeography, 38:783-791

- Fegel T, Baron J, Fountain A, Johnson G and Hall E (2016) The differing biogeochemical and microbial signatures of glaciers and rock glaciers. Journal of Geophysical Research: Biogeosciences, 123:919-932

- Forero-Medina G, Joppa L and Pimm S (2011) Constraints to species' elevational range shifts as climate changes. Conservation Biology, 25(1):163-171

- Fountain A (1985) The effect of glaciers on streamflow variations. Water Resources Research, 24(4):579-586

- Fountain A (1996) Effect of snow and firn hydrology on the physical and chemical characteristics of glacial runoff. Hydrological Processes, 10:509521

- Francou B, Fabre D, Pouyaud B, Jomelli V and Arnaud Y (1999) Symptoms of degradation in a tropical rock glacier, Bolivian Andes. Permafrost and Periglacial Processes, 10:91-100

- Frauenfelder H (2005) Regional scale modeling of the occurrence and dynamics of rock glaciers and the distribution of paleo permafrost. PhD Thesis, Geographisches Institut der Universitat Zurich

- Fremier A, Kiparsky M, Gmur S, Aycrigg J, Craig R, Svancara L, ... and Scott J (2015) A riparian conservation network for ecological resilience. Biological Conservation, 191:29-37 
- Garrity C and Soller D (2009) Database of the Geologic Map of North America: Adapted from map by J.C. Reed and others (2005). U.S. Geological Survey, Reston, VA

- Geiger S, Daniels J, Miller S and Nicholas J (2014) Influence of rock glaciers on stream hydrology in the La Sal Mountains, Utah. Arctic, Antarctic and Alpine Research, 46(3):645-658

- Haeberli W (1985) Creep of mountain permafrost: internal structure and flow of alpine rock glaciers. Mitteilung der VAW/ETH Zürich 17, 221

- Haeberli W, Hallet B, Arenson L, Elconin R, Humlum O, Kaab A, Kaufmann V, Ladanyi B, Matsuoka N, ... and Muhll D (2006) Permafrost creep and rock glacier dynamics. Permafrost and Periglacial Processes, 14:189-214

- Harris C, Arensons L, Christiansen H, Etzelmuller B, Frauenfelder R, Gruber S, Haeberli W, Hauck C, Holzle M, Humlum O, Isaksen K, Kaab A, Kern M, Lehning M, Matsuoka N, Murton J, Notzli J, ..., and Muhl D. (2009) Permafrost and climate in Europe: Monitoring and modelling thermal, geomorphological and geotechnical responses. Earth-Science Reviews, 94(3):117-171

- Hewitt K (2011) Glacier change, concentration, and elevation effects in the Karakoram Himalaya, Upper Indus Basin. Mountain Research and Development, 31(3):188-200

- Higuchi K, lozawa T, Fuji Y and Kodama H (1980) Inventory of perennial snow patches in Central Japan. GeoJournal, 4.4:303-311

- Hillyer R and Silman M (2010) Changes in species interactions across a $2.5 \mathrm{~km}$ elevation gradient: Effects on plant migration in response to climate change. Global Change Biology, 16:3205-3214

- Hock R, Johansson M, Jansson P and Barring L (2002) Modeling climate conditions required for glacier formation in cirques of the 
Rassepautasitiakka Massif, northern Sweden. Arctic, Antarctic and Alpine Research, 34(1):3-11

- Homer C, Dewitz J, Yang L, Jin S, Danielson P, Xian G, Coulston J, Herold $\mathrm{N}$, Wickham J and Megown K (2015) Completion of the 2011 National Land Cover Database for the conterminous United States: Representing a decade of land cover change information. Photogrammetric Engineering and Remote Sensing, 81(5):345-354

- Humlum O (1998) The climatic significance of rock glaciers. Permafrost and Periglacial Processes, 9(4):375-395

- Humlum O (2000) The geomorphic significance of rock glaciers: Estimates of rock glacier debris volumes and headwall recession rates in West Greenland. Geomorphology, 35:41-67

- Imhof M (1996) Modelling and verification of the permafrost distribution in the Bernese Alps (Western Switzerland). Permafrost and Periglacial Processes, 7(3), 267-280.

- International Hydrological Decade (1970). Seasonal snow cover: a guide for measurement compilation and assemblage of data. Paris, UNESCO/I ASH/WMO. 38 p. (Technical Papers in Hydrology, 2.)

- Iribarren P and Bodin X (2010) Geomorphic consequences of two large glacier and rock glacier destabilizations in the Central Chilean Andes. Geophysical Research Abstracts, 12:EGU2010-7162-4

- Janke J (2007) Colorado Front Range rock glaciers: Distribution and topographic characteristics. Arctic, Antarctic and Alpine Research, 39(1):74-83

- Janke J and Frauenfelder R (2008) The relationship between rock glaciers and contributing area parameters in the Front Range of Colorado. Journal of Quaternary Science, 23(2):153-163 
- Janke J, Bellisario A and Ferrando F (2015) Classification of debriscovered glaciers and rock glaciers in the Andes of central Chile. Geomorphology, 241:98-121

- Johnson G, Chang H and Fountain A (2018) Rock glaciers of the Contiguous United States: GIS inventory, spatial distribution patterns and geographically explicit modeling. Manuscript In Preparation

- Kaab A and Reichmuth T (2005) Advance mechanisms or rock glaciers. Permafrost and Periglacial Processes, 16:187-193

- Karl T and Koss W (1984) Regional and national monthly, seasonal and annual temperature weighted by area, 1895-1983. Historical Climatology Series 4-3, National Climatic Data Center, Asheville, NC, 1-38

- Ke Y, Im J, Lee J, Gong H and Ryu Y (2015) Characteristics of Landsat 8 OLI-derived NDVI by comparison with multiple satellite sensors and in-situ observations. Remote Sensing of the Environment, 164:298-313

- Kellerer-Pirklbauer A, Lieb G and Kleinferchner H (2012) A new rock glacier inventory of the eastern European Alps. Austrian Journal of Earth Sciences, 105(2):78-93

- Kenner R and Magnusson J (2017) Estimating the effect of different influencing factors on rock glacier development in two regions in the Swiss Alps. Permafrost and Periglacial Processes, 28(1):195-208.

- Klapyta P (2013) Application of Schmidt hammer relative age dating to Late Pleistocene moraines and rock glaciers in the Western Tatra Mountains, Slovakia. Catena, 111:104-121

- Konrad S and CLark D (1998) Evidence for an early neoglacial glacier advance from rock glaciers and lake sediments in the Sierra Nevada, California, U.S.A. Arctic, Antarctic and Alpine Research, 30(3):272-284

- Konrad S, Humphrey N, Steig E, Clark D, Potter N and Pfeffer W (1999) Rock glacier dynamics and paleoclimatic implications. Geology, 27:11311134 
- Krainer K and Mostler w (2002) Hydrology of active rock glaciers:

Examples from the Austrian Alps. Arctic, Antarctic, and Alpine Research, 34(2):142-149

- Krainer K and Ribis M (2012) A rock glacier inventory of the Tyrolean Alps (Austria). Austrian Journal of Earth Sciences, 105(2):32-74

- Lambiel C and Reynard E (2001) Regional modeling of present, past and future distribution of discontinuous permafrost based in a rock glacier inventory in the Bagnes-Heremence area (western Swiss Alps). Norwegian Journal of Geography, 55:219-233

- Langston G, Bentley LR, Hayashi M, McClymont A and Pidlisecky A (2011) Internal structure and hydrological functions of an alpine moraine. Hydrological Processes, 25(19):2967-2982

- Lillehammer A and Brittain JE (1978) The invertebrate fauna of the streams in Ovre Heimdalen. Holarctic Ecology, 1:271-276

- Liu L, Millar C, Westfall and Zebker H (2013) Surface motion of active rock glaciers in the Sierra Nevada, California, USA: inventory and a case study using InSAR. The Cryosphere, 7:1109-1119

- Lugon R and Stoffel M (2010) Rock-glacier dynamics and magnitudefrequency relations of debris flows in a high-elevation watershed: Ritigraben, Swiss Alps. Global and Planetary Change, 73:202-210

- Matthews J, Nesje A and Linge H (2013) Relict talus-foot rock glaciers at Øyberget, Upper Ottadalen, Southern Norway: Schmidt Hammer exposure ages and palaeoenvironmental implications. Permafrost and Periglacial Processes, 24(4):336-346

- Millar C and Westfall R (2008) Rock glaciers and related periglacial landforms in the Sierra Nevada, CA, U.S.A.; inventory, distribution and climatic relationships. Quaternary International, 188:90-104 
- Millar C, Westfall R and Delany D (2013a) Thermal and hydrologic attributes of rock glaciers and periglacial talus landforms: Sierra Nevada, California, U.S.A. Quaternary International, 310:169-180

- Millar C, Westfall R, Evenden A, Holmquist J, Schmidt-Gengenbach J, Franklin R, ... and Delaney D (2013b) Potential climatic refugia in semiarid, temperate mountains: Plant and arthropod assemblages associated with rock glaciers, talus slopes, and their forefield wetlands, Sierra Nevada, California, U.S.A. Quaternary International, 387:106-121

- Monahan W, Cook T, Melton F, Connor J and Bobowski B (2013) Forecasting distributional responses of Limber Pine to climate change at management-relevant scales in Rocky Mountain National Park. Public Library of Science One, 8(12):1-10

- Monnier S and Kinnard C (2015) Reconsidering the glacier to rock glacier transformation problem: New insights from the central Andes of Chile. Geomorphology, 238:47-55

- Morueta-Holme N, Engemann K, Sandoval-Acuna P, Jonas J, Segnitz R and Svenning J (2015) Strong upslope shifts in Chimborazo's vegetation over two centuries since Humboldt. PNAS, 112(41):12741-12745

- Mote P, Hamlet A, Clark M and Lettenmaier D (2005) Declining mountain snowpack in western North America. Bulletin of the American Meteorological Association, 86(1):39-49

- Muhlfeld C, Giersch J, Hauer F, Pederson G, Luikart G, Peterson D, ... and Fagre $D$ (2011) Climate change links fate of glaciers and an endemic alpine invertebrate. Climatic Change, 106(2):337-345

- Navarro F and Magnusson M (2017) Position paper of the International Glaciological Society on standard practices regarding glacier inventories. International Glaciological Society, December 21, 2017

- Nazeer M, Nichol JE and Yung Y (2014) Evaluation of atmospheric correction models and Landsat surface reflectance product in an urban 
coastal environment. International Journal of Remote Sensing, 35(16):6271-6291

- NOAA (201) NOAA National Centers for Environmental Information, State of the Climate: National Climate Report for Annual 2016, published online January 2017, retrieved on April 15, 2018 from

https://www.ncdc.noaa.gov/sotc/national/201613.

- Nussear K, Esque T, Inman R, Gass L, Thomas K, Wallace C, Blainey J, Miller D and Webb R (2009) Modeling Habitat of the Desert Tortoise (Gopherus agassizii) in the Mojave and Parts of the Sonoran Deserts of California, Nevada, Utah, and Arizona. U.S. Geological Survey Open-File Report 2009-1102

- Pauritsch M, Birk S, Wagner T, Hergarten S and Winkler G (2015) Analytical approximations of discharge recessions for steeply sloping aquifers in alpine catchments. Water Resources Research, 51:8729-8740

- Pauritsch M, Birk S, Wagner T, Hergarten S and Winkler G (2015) Analytical approximations of discharge recessions for steeply sloping aquifers in alpine catchments. Water Resources Research, DOI:10.1002/2015WR017749

- Perucca L and Angillieri M (2011) Glaciers and rock glaciers' distribution at 28A degrees SL, Dry Andes of Argentina, and some considerations about their hydrological significance. Environmental Earth Sciences, 64(8):20792089

- Potter N (1972) Ice-cored rock glacier, Galena Creek, Northern Absaroka Mountains, Wyoming. Geological Society of America Bulletin, 83:30253058

- PRISM (2017) Climate Group, Oregon State University, http://prism.oregonstate.edu, created 1 July 2015 
- Rangecroft S, Harrison S, Anderson K, Magrath J, Castel AP and Pacheco P (2014) A first rock glacier inventory for the Bolivian Andes. Permafrost and Periglacial Processes, 25:333-343

- RGI Consortium (2017) Randolph Glacier Inventory: A dataset of global glacier outlines: Version 6.0: Technical Report, Global Land Ice Measurements from Space, Colorado, USA. Digital Media. DOI: https://doi.org/10.7265/N5-RGI-60

- Rode M and Kellerer-Pirklbauer A (2011) Schmidt-hammer exposure-age dating (SHD) of rock glaciers in the Schöderkogel-Eisenhut area, Schladminger Tauern Range, Austria. The Holocene, 22(7):761-771

- Sabo J, Sponseller R, Dixon M, Grade K, Harms T, Heffernan J, ... and Welter J (2005) Riparian zones increase regional species richness by harboring different, not more, species. Ecology, 86(1):56-62

- Sandel B, Arge L, Dalsgaard B, Davies R, Gaston K, Sutherland W and Svenning J (2011) The influence of Late Quaternary climate-change velocity on species endemism. Science, 334:660-664

- Scotti R, Brardinoni F, Albereti S, Frattini P and Crosta G (2013) A regional inventory of rock glaciers and protalus ramparts in the central Italian Alps. Geomorphology, 186:136-149

- Senn A (1976) Large sample-size distribution of statistics used in testing for spatial correlation. Geographical Analysis, 8(2):175-184

- Seppi R, Carton A, Zumiani M., Dall'Amico G, Zampedri R and Rigon R (2012) Inventory, distribution and topographic features of rock glaciers in the southern region of the Eastern Italian Alps (Trentino). Geografia Fisica E Dinamica Quaternaria, 35(2):185-197

- Sicart J, Hock R and Six D (2008) Glacier melt, air temperature, and energy balance in different climates: The Bolivian Tropics, the French Alps, and northern Sweden. Journal of Geophysical Research: Atmospheres, 113(24):D24113, doi:10.1029/2008JD010406 
- Simon A, Curini A, Darby S and Langendoen (2006) Bank and near-bank processes in an incised channel. Geomorphology, 34(3):193-217

- Slemmons K, Saros J and Simon K (2013) The influence of glacial meltwater on alpine aquatic ecosystems: A review. Environmental Science Processes, 15:1794-1806

- Sorg A, Kaab A, Roesch A, Bigler C and Stoffel M (2015) Contrasting responses of Central Asian rock glaciers to global warming. Scientific Reports 5, doi:10.1038/srep08228

- Stenni B, Genoni L, Flora O and Guglielmin M (2007) An oxygen isotope record from the Foscagno rock-glacier ice core, Upper Valtellina, Italian Central Alps. The Holocene, 17(7):1033-1039

- Sulejman R (2011) Phytogeographic and syntaxonomic diversity of high mountain vegetation in Dinaric Alps (Western Balkan, SE Europe). Journal of Mountain Science, 8:767-786

- Tian F, Fensholt R, Verbesselt J, Grogan K, Horion S and Wang Y (2015) Evaluating temporal consistency of long-term global NDVI datasets for trend analysis. Remote Sensing of Environment, 163:326-340

- Tiefelsdorf M (2002) The saddlepoint approximation of Moran's I's and Local Moran's li's reference distributions and their numerical evaluation. Geographical Analysis, 34(3):187-206

- USGS (2013) National Hydrography Geodatabase (NHD). U.S. Geological Survey, Sioux Falls, South Dakota

- USGS (2017) The National Elevation Dataset (NED). U.S. Geological Survey, Sioux Falls, South Dakota

- Wagner T, Pauritsch M and Winkler G (2016) Impact of relict rock glaciers on spring and stream flow of alpine watersheds: Examples of the Niedere Tauern Range, Eastern Alps (Austria). Austrian Journal of Earth Sciences, 109(1):84-98 
- Wang Q, Shuang Y and Sun W (2017) Precipitation-driven glacier changes in the Pamir and Hindu Kush mountains. Geophysical Research Letters, 44(6):2817-2824

- Whalley WB, Matsuoka N, Sik A, Kereszturi Á and Hargitai H (2014) Rock Glacier and Debris-Covered Glacier. Encyclopedia of Planetary Landforms, Springer, New York, NY

- Wickham J, Stehman SV, Gass L, Dewitz JA, Sorenson DG, Granneman BJ, Poss RV and Baer LA (2017) Thematic accuracy assessment of the 2011 National Land Cover Database (NLCD). Remote Sensing of the Environment, 191:328-341

- Yang X, Qin D, Zhang T, Kang S, Qin X and Liu H (2010) Seasonal characteristics of surface radiation fluxes on the East Rongbuk Glacier in the Mt. Everest region. Journal of Meteorological Research, 6:680-698

- Zah R and Uehlinger U (2001) Particulate organic matter inputs to a glacial stream ecosystem in the Swiss Alps. Freshwater Biology, 46:15971608

- Zasadni J (2007) The Little Ice Age in the Alps: Its record in glacial deposits and rock glacier formation. Landform Evolution in Mountain Areas, 41:117-137 